\title{
Picolyl-NHC Hydrotris(pyrazolyl)borate Ruthenium(II) Complexes: Synthesis, Characterization, and Reactivity with Small Molecules
}

\author{
Francys E. Fernández, M. Carmen Puerta,* and Pedro Valerga* \\ Departamento de Ciencia de los Materiales e Ingeniería Metalúrgica y Química Inorgánica, Facultad de Ciencias, Universidad de \\ Cádiz, 11510 Puerto Real, Cádiz, España
}

\section{Supporting Information}

ABSTRACT: Ruthenium(II) hydrotris(pyrazolyl)borate chloro complexes bearing picolyl-functionalized N-heterocyclic carbenes $[\mathrm{TpRu}-$ $\left(\boldsymbol{\kappa}^{2}-\mathrm{C}, \mathrm{N}\right.$-picolyl- $\left.\left.{ }^{R} \mathrm{I}\right) \mathrm{Cl}\right]$ (picolyl- ${ }^{M e} \mathrm{I}=3$-methyl-1-(2-picolyl)imidazol-2ylidene) (1a), picolyl ${ }^{i P r} \mathrm{I}=3$-isopropyl-1-(2-picolyl)imidazol-2-ylidene (1b), picolyl- ${ }^{M e} 45 D C l I=3$-methyl-1-(2-picolyl)-4,5-dichloroimidazol2-ylidene (1c), picolyl- ${ }^{P h} \mathrm{I}=3$-phenyl-1-(2-picolyl)imidazol-2-ylidene (1d), picolyl- ${ }^{M e} \mathrm{BI}=3$-methyl-1-(2-picolyl)benzoimidazol-2-ylidene (1e)) have been synthesized and characterized. Furthermore, cationic carbonyl derivatives $\mathbf{2 a}-\mathbf{e}$ have been prepared, characterized, and used to study the donor properties of the picolylcarbene ligands (picolyl- ${ }^{R} \mathbf{I}$ ) via infrared spectroscopy. Also, the reactivity of the 16-electron species $\left[\mathrm{TpRu}\left(\boldsymbol{\kappa}^{2}-\mathrm{C}, \boldsymbol{N} \text {-picolyl- }{ }^{R} \mathbf{I}\right)\right]^{+}$, in situ generated using $\mathrm{NaBAr}_{4}{ }_{4}\left(\mathrm{Ar}^{\mathrm{F}}=\right.$

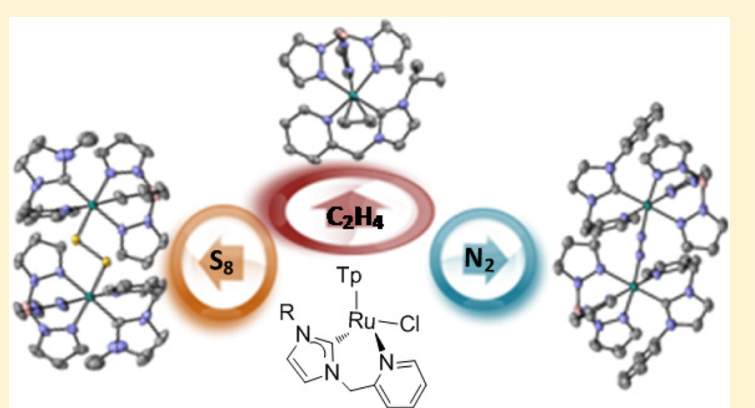
3,5-bis(trifluoromethyl)phenyl) as a halide scavenger, toward $\mathrm{N}_{2}, \mathrm{CH}_{3} \mathrm{CN}, \mathrm{H}_{2}, \mathrm{CH}_{2} \mathrm{CH}_{2}$, $\mathrm{S}_{8}$, and $\mathrm{O}_{2}$ was studied indicating a strong influence of the NHC wingtip and backbone substituents in the product distribution. The crystal structures of [TpRu $\left(\kappa^{2}-\right.$ $C, N$-picolyl- $\left.\left.{ }^{i P r} \mathrm{I}\right) \mathrm{Cl}\right](\mathbf{1 b}),\left[\mathrm{TpRu}\left(\kappa^{2}-C, N\right.\right.$-picolyl- $\left.\left.{ }^{M e} \mathrm{I}\right) \mathrm{CO}\right]\left[\mathrm{BAr}^{\mathrm{F}}{ }_{4}\right](\mathbf{2 a}),\left[\mathrm{TpRu}\left(\kappa^{2}-C, N\right.\right.$-picolyl- $\left.\left.{ }^{P h} \mathrm{I}\right) \mathrm{CO}\right]\left[\mathrm{BAr}{ }_{4}^{\mathrm{F}}\right](\mathbf{2 d}),\left[\left\{\mathrm{TpRu}^{-} \kappa^{2}-\right.\right.$

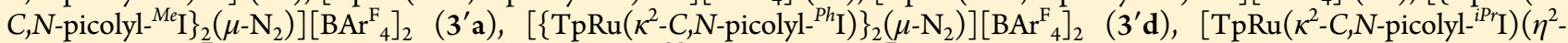
$\left.\left.\mathrm{CH}_{2} \mathrm{CH}_{2}\right)\right]\left[\mathrm{BAr}^{\mathrm{F}}{ }_{4}\right](\mathbf{5 b})$, and $\left[\left\{\mathrm{TpRu}\left(\kappa^{2}-\mathrm{C}, N \text {-picolyl- }{ }^{M e} \mathrm{I}\right)\right\}_{2}\left(\mu-\mathrm{S}_{2}\right)\right]\left[\mathrm{BAr}_{4}^{\mathrm{F}}\right]_{2}(\mathbf{6})$ are reported.

\section{INTRODUCTION}

Bidentate N-heterocyclic carbene (NHC) based ligands have been widely used in organometallic chemistry for the synthesis of homogeneous catalysts. ${ }^{1}$ The potential hemilability of the new donor group, capable of reversible dissociation from the metal center, ${ }^{2}$ has led to the synthesis of NHCs functionalized with phosphine, ${ }^{3}$ pyrimidine, ${ }^{4}$ ether, ${ }^{5}$ thioether, ${ }^{6}$ carboxylate, ${ }^{7}$ indenyl, ${ }^{8}$ oxazoline, ${ }^{9}$ and pyridine. ${ }^{10}$ Ligands with nitrogen donors have attracted most attention; particularly, metal complexes bearing pyridine functionalized NHCs of $\mathrm{Ir}^{11}$ $\mathrm{Ag},{ }^{12} \mathrm{Pd},{ }^{13} \mathrm{Ru},{ }^{14}$ and $\mathrm{Ni}^{15}$ have been synthesized. Among nitrogen donors, picoline has been used to generate $N$-picolylNHC ligands, which can be easily synthesized with different substitution patterns on the picoline ring and the NHC. ${ }^{16}$ This leads to a versatile ligand group toward the study of coordination properties.

Since its introduction by Trofimenko in 1966, the hydrotris(pyrazolyl)borate (Tp) ligand has been extensively used as a spectator ligand in transition metal chemistry because it binds strongly to metals and is resistant toward electrophilic and nucleophilic attacks. ${ }^{17} \mathrm{Tp}$ is generally compared with $\mathrm{C}_{5} \mathrm{R}_{5}$ due to the fact that both of them donate the same number of electrons (6 electrons) and adopt a facial geometry generating typically half-sandwich complexes. However, there are noteworthy differences between the two ligand classes. ${ }^{18}$ The cone angle of $\mathrm{Tp}$ is close to $180^{\circ}$ well above the $100^{\circ}$ and $146^{\circ}$ estimated for $\mathrm{C}_{5} \mathrm{H}_{5}$ and $\mathrm{C}_{5} \mathrm{Me}_{5}$, respectively. Thus the steric bulk of Tp disfavors higher coordination numbers of the metal center. Also, Tp ligand has lower field strength compared with $\mathrm{C}_{5} \mathrm{R}_{5}$ ligands, with its nitrogen atoms acting as $\sigma$ donors, while $\mathrm{C}_{5} \mathrm{R}_{5}$ group is capable of $\pi$ donation. Besides, the $[\mathrm{TpRu}]^{+}$ preferentially adopts a six-coordinated structure, in contrast with $\mathrm{C}_{5} \mathrm{R}_{5}$ analogues that are capable of forming sevencoordinated species. Ruthenium compounds with cyclopentadienyl type ligands have been broadly studied because they are able to give rise to metastable 16-electron species with many potential catalytic applications. ${ }^{19}$ Particularly, halfsandwich ruthenium complexes bearing monodentate NHCs have proven to be active in olefin metathesis, ${ }^{20}$ racemization of chiral alcohols, ${ }^{21}$ alkyne dimerization, ${ }^{22}$ and isomerization of allylic alcohols. ${ }^{23}$ Also, our group has recently synthesized a series of $\left[\left(\eta^{5}-\mathrm{C}_{5} \mathrm{Me}_{5}\right) \mathrm{Ru}\left(\kappa^{2}-C, N\right.\right.$-picolyl-NHCs $\left.) \mathrm{CH}_{3} \mathrm{CN}\right]\left[\mathrm{PF}_{6}\right]$ complexes and studied the influence of $\mathrm{N}$-heterocyclic carbene ligands in catalytic transfer hydrogenation of ketones and imines. ${ }^{24}$ However, ruthenium hydrotris(pyrazolyl)borate complexes bearing NHCs are rare; to the best of our knowledge, only two examples of $\mathrm{Tp}$-ruthenium complexes bearing a monodentate NHC have been reported. In 2001, Grubbs and co-workers published the synthesis of $\left[\left(\kappa^{3}-\mathrm{Tp}\right)\left(\mathrm{IMesH}_{2}\right)(\mathrm{Cl})\right.$ $\mathrm{Ru}=\mathrm{CHPh}]$ shown in Figure 1a upon studying the reactivity of

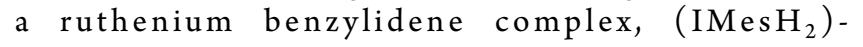

Received: November 21, 2012

Published: March 26, 2013 


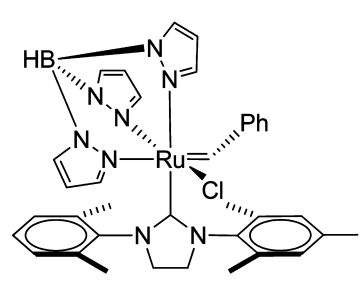

(a)

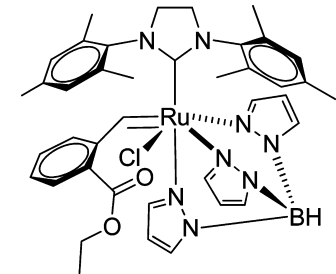

(b)

Figure 1. (a) $\left[\left(\kappa^{3}-\mathrm{Tp}\right)\left(\mathrm{IMesH}_{2}\right)(\mathrm{Cl}) \mathrm{Ru}=\mathrm{CHPh}\right]^{25}$ and $(\mathrm{b})\left[\left(\kappa^{3}-\right.\right.$ $\left.\mathrm{Tp}) \mathrm{Ru}\left(\mathrm{IMesH}_{2}\right)(\mathrm{Cl}) \mathrm{Ru}=\mathrm{CH}(2-\mathrm{COOEtPh})\right]^{26}$

$(\mathrm{Cl})_{2}\left(\mathrm{C}_{5} \mathrm{H}_{5} \mathrm{~N}_{2}\right)_{2} \mathrm{Ru}=\mathrm{CHPh}^{25}$ In addition, Burtscher et al. reported the synthesis of $\left[\left(\kappa^{3}-\mathrm{Tp}\right) \mathrm{Ru}\left(\mathrm{IMesH}_{2}\right)(\mathrm{Cl}) \mathrm{Ru}=\mathrm{CH}(2\right.$ $\mathrm{COOEtPh})]$ presented in Figure $1 \mathrm{~b}$ while studying the reactivity of (SPY-5-34)-dichloro $\left(\kappa^{2}-(\mathrm{C}, \mathrm{O})-2\right.$ ethoxycarbonylbezylidene) $\left(\mathrm{H}_{2} \mathrm{IMes}\right)$ ruthenium ( $\mathrm{SPY}=$ square pyramidal; $5=$ coordination number; $34=$ diastereoisomer index). ${ }^{26}$ Thus, $\mathrm{Tp}$-ruthenium complexes containing functionalized N-heterocyclic carbene ligands have not been reported, and they represent a new ruthenium scaffold for the exploration of reactivity and its application on several catalytic processes.

Our group has broad experience with the stoichiometric chemistry of hydrotris(pyrazolyl)borate ruthenium complexes bearing $\mathrm{PR}_{3}, \mathrm{P}, \mathrm{P}$, and $\mathrm{P}, \mathrm{N}$ ligands. ${ }^{27} \mathrm{We}$ aim to replace the phosphine fragment by an NHC to study the effect of the new ligands in the reactivity of the metal center. In this work, we describe a series of novel hydrotris(pyrazolyl)borate ruthenium(II) picolyl-NHC complexes in which the ligands have been varied systematically. In addition, small molecule activation is an area of interest, considering its significant impact in several biological, industrial, and environmental processes. The in situ generation of the 16-electron fragment, $\left[\mathrm{TpRu}\left(\kappa^{2}-C, N\right.\right.$-picolyl$\mathrm{NHC})]^{+}$, using a halide scavenger, $\mathrm{NaBAr}_{4}^{\mathrm{F}}\left(\mathrm{Ar}^{\mathrm{F}}=3,5-\right.$ bis(trifluoromethyl)phenyl), allowed us to study the reactivity of the new ruthenium compounds toward small molecules, such as $\mathrm{CO}, \mathrm{N}_{2}, \mathrm{CH}_{3} \mathrm{CN}, \mathrm{H}_{2}, \mathrm{CH}_{2} \mathrm{CH}_{2}, \mathrm{~S}_{8}$, and $\mathrm{O}_{2}$. The crystal structures of $\left[\mathrm{TpRu}\left(\kappa^{2}-C, N\right.\right.$-picolyl- $\left.\left.{ }^{i P r} \mathrm{I}\right) \mathrm{Cl}\right](\mathbf{1 b}),\left[\mathrm{TpRu}\left(\kappa^{2}-\right.\right.$ $C, N$-picolyl- $\left.\left.{ }^{M e} \mathrm{I}\right) \mathrm{CO}\right]\left[\mathrm{BAr}_{4}^{\mathrm{F}}\right] \quad(\mathbf{2 a}),\left[\mathrm{TpRu}\left(\kappa^{2}-C, N\right.\right.$-picolyl- $\left.{ }^{P h} \mathrm{I}\right)-$ $\mathrm{CO}]\left[\mathrm{BAr}_{4}^{\mathrm{F}}\right] \quad(\mathbf{2 d}), \quad\left[\left\{\mathrm{TpRu}\left(\kappa^{2}-C, N \text {-picolyl }-{ }^{M e} \mathrm{I}\right)\right\}_{2}\left(\mu-\mathrm{N}_{2}\right)\right]-$ $\left[\mathrm{BAr}^{\mathrm{F}}{ }_{4}\right]_{2}\left(3^{\prime} \mathrm{a}\right),\left[\left\{\mathrm{TpRu}\left(\kappa^{2}-C, N \text {-picolyl }-{ }^{P h} \mathrm{I}\right)\right\}_{2}\left(\mu-\mathrm{N}_{2}\right)\right]\left[\mathrm{BAr}^{\mathrm{F}}{ }_{4}\right]_{2}$ $\left(3^{\prime} \mathrm{d}\right),\left[\mathrm{TpRu}\left(\kappa^{2}-\mathrm{C}, N\right.\right.$-picolyl $\left.\left.{ }^{i{ }^{i r} \mathrm{I}} \mathrm{I}\right)\left(\eta^{2}-\mathrm{CH}_{2} \mathrm{CH}_{2}\right)\right]\left[\mathrm{BAr}^{\mathrm{F}}{ }_{4}\right](\mathbf{5 b})$, and $\left[\left\{\mathrm{TpRu}\left(\kappa^{2}-C, N \text {-picolyl- }{ }^{M e} \mathrm{I}\right)\right\}_{2}\left(\mu-\mathrm{S}_{2}\right)\right]\left[\mathrm{BAr}^{\mathrm{F}}{ }_{4}\right]_{2}$ (6) have been determined, in order to contribute to the scarce crystallographic library of $\mathrm{Tp}$-ruthenium NHC complexes. After a judicious literature search, it is remarkable that here we report the first example of structural characterization of a $\mathrm{TpRu}$ disulfide complex $\left[\mathrm{Tp}\left(\kappa^{2}-C, N\right.\right.$-picolyl- $\left.{ }^{M e} \mathrm{I}\right) \mathrm{Ru}-\mathrm{S}-\mathrm{S}-\mathrm{RuTp}\left(\kappa^{2}-\right.$ $C, N$-picolyl- $\left.\left.{ }^{M e} \mathrm{I}\right)\right]^{2+}, \mathbf{6}$, along with the first $\mathrm{TpRu}$ dinitrogen bridged complexes bearing an NHC $\left[\mathrm{Tp}\left(\kappa^{2}-C, N\right.\right.$-picolyl- $\left.{ }^{R} \mathrm{I}\right)$ $\mathrm{Ru}-\mathrm{N} \equiv \mathrm{N}-\mathrm{Ru}\left(\kappa^{2}-C, N\right.$-picolyl- $\left.\left.{ }^{R} \mathrm{I}\right) \mathrm{Tp}\right]^{2+}, 3^{\prime} \mathbf{a}$ and $3^{\prime} \mathrm{d}$, and the first $\mathrm{TpRu}$ ethylene complex, $\left[\mathrm{TpRu}\left(\kappa^{2}-C, N\right.\right.$-picolyl $\left.{ }^{i P r} \mathrm{I}\right)-$ $\left.\left(\mathrm{CH}_{2} \mathrm{CH}_{2}\right)\right]^{+}$, 5b. There is only one additional example of structural characterization of a $\mathrm{TpRu}$ dinitrogen bridged complex containing $\mathrm{PCy}_{3}$ as a ligand. ${ }^{28}$

\section{RESULTS AND DISCUSSION}

Synthesis of $\kappa^{3}$-Hydrotris(pyrazolyl)borate PicolylNHC Ru(II) Complexes. The Ru(II) neutral complexes 1ae (Scheme 1) have been prepared upon treatment of the metal precursor $[\mathrm{TpRu}(\mathrm{COD}) \mathrm{Cl}]$ with a solution of the appropriate silver carbene, previously generated via reaction of silver oxide and picolyl imidazolium salts, a-e, in 1,2-dichloroethane.

Scheme 1

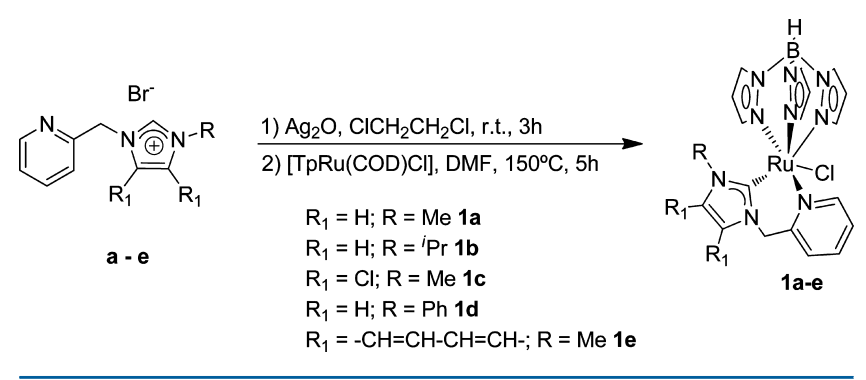

Initially, the synthetic route of choice was the in situ generation of the free carbene by treatment of the picolyl imidazolium salts with a strong base (i.e., $\mathrm{Li}^{n} \mathrm{Bu}$ or $\mathrm{KO}^{t} \mathrm{Bu}$ ) in THF, followed by the addition of the metal precursor. However, a mixture of products and starting material, as evidenced in the ${ }^{1} \mathrm{H}$ NMR spectra of the reaction mixture, was obtained in all cases. $\mathrm{TpRu}\left(\mathrm{PPh}_{3}\right)_{2} \mathrm{Cl}$ was also used as an alternative metal precursor, but the presence of coordinated phosphine in the generated products was evident in every attempt, in addition to an uncharacterizable mixture of complexes. Hence, the transmetalation method was the route of choice to afford the new $\mathrm{Ru}(\mathrm{II})$ complexes $\mathbf{1 a}-\mathbf{e}$, given that we had previously synthesized $\left[\left(\eta^{6}-p\right.\right.$-cymene $) \mathrm{Ru}^{\mathrm{II}}($ picolyl-NHC$\left.) \mathrm{Cl}\right]\left[\mathrm{PF}_{6}\right]$ using this method. ${ }^{29}$ It is very important to note that after the metal precursor is added, the reaction mixture needs to be heated at high temperatures $\left(150{ }^{\circ} \mathrm{C}\right)$ to complete the transmetalation process and that the desired products were not synthesized using a solvent other than DMF. Previously, Kirchner and coworkers have demonstrated that the COD ligand in the $[\mathrm{TpRu}(\mathrm{COD}) \mathrm{Cl}]$ precursor is substitutionably inert; only prolonged heating and high temperatures in boiling DMF led to $\left[\mathrm{TpRu}\left(\mathrm{L}_{2}\right) \mathrm{Cl}\right]$ or $\left[\mathrm{TpRu}(\mathrm{L})_{2} \mathrm{Cl}\right]\left(\mathrm{L}=\mathrm{PPh}_{3}, \mathrm{py}, \mathrm{PCy}_{3}\right.$, $\mathrm{AsPh}_{3}, \mathrm{CH}_{3} \mathrm{CN} ; \mathrm{L}_{2}=$ tmeda, dppm, acac) products. ${ }^{30}$ In our case, the silver picolyl-carbenes are stable under these conditions, and upon heating the reaction mixture for $5 \mathrm{~h}$ at $150{ }^{\circ} \mathrm{C}$, 1a-e were obtained in high yields (over 78\%) in all cases. The new $\mathrm{Ru}(\mathrm{II})$ compounds were characterized by ${ }^{1} \mathrm{H}$ and ${ }^{13} \mathrm{C}\left\{{ }^{1} \mathrm{H}\right\}$ NMR and elemental analysis. All these ruthenium picolyl-NHC complexes are very soluble in THF, acetone, and chlorinated solvents but insoluble in other solvents such as hexane, $\mathrm{Et}_{2} \mathrm{O}$, and petroleum ether.

${ }^{1} \mathrm{H}$ NMR spectra of compounds $1 \mathrm{a}-\mathrm{e}$ lack the $\mathrm{C}_{2}$ imidazolium proton resonance signals at 10-12 ppm, indicating the coordination of the $\mathrm{C}_{2}$ carbene carbon to the metal center. Also, there are two characteristic $\mathrm{AB}$ doublet signals with coupling constants of $14-15 \mathrm{~Hz}$ corresponding to the methylene bridge protons, which become diastereotopic after coordination of the ligands to the $\mathrm{Ru}$ atom given the $\kappa^{2}-\mathrm{C}, \mathrm{N}$ coordination. One of the methylene proton signals is particularly shifted to a lower field, up to $7.2 \mathrm{ppm}$, in comparison with other ruthenium picolyl-NHC complexes. $^{29,31}$ Similar NMR features on $\left(\eta^{5}-\mathrm{C}_{5} \mathrm{Me}_{5}\right) \mathrm{Ru}$ and $\left(\eta^{6}\right.$ $p$-cymene) $\mathrm{Ru} \kappa^{2}$-P,N complexes bearing chelating phosphinopicoline or chelating $\kappa^{2}-\mathrm{C}, \mathrm{N}$ pyridyl-NHC ligands have been observed. ${ }^{29,31,32}$ Also, all nine nonequivalent characteristic Tp signals are observed in the ${ }^{1} \mathrm{H}$ NMR spectrum. The ${ }^{13} \mathrm{C}\left\{{ }^{1} \mathrm{H}\right\}$ NMR signals of the carbene carbons atoms of 1a-e (192-211 $\mathrm{ppm})$ are located as expected for $\mathrm{Ru}-\mathrm{NHC}$ compounds. ${ }^{19-24,29,31,32}$ It is interesting to note the displacement to lower field, up to $211 \mathrm{ppm}$, of the NMR resonance of the $\mathrm{C}_{2}$ carbon atom corresponding to the benzoimidazol compound 
1e. It is possible to explain this observation due to destabilization in the imidazolium ring conjugation produced by the attached benzene ring, which leads to a lower electron density in the $\mathrm{C}_{2}$ carbon. In addition, this behavior was evidenced in the previous synthesis of the $\left(\eta^{5}-\mathrm{C}_{5} \mathrm{Me}_{5}\right) \mathrm{Ru}$ and $\left(\eta^{6}\right.$-p-cymene $) \mathrm{Ru}$ picolyl-NHC analogues. ${ }^{24,29,31}$

Crystals of $\mathbf{1 b}$ suitable for X-ray diffraction were obtained by slow diffusion of hexane in a dichloromethane solution. ORTEP diagram of the ruthenium(II) complex is displayed in Figure 2. From the mother liquor, a second set of $\mathbf{1 b}$ crystals

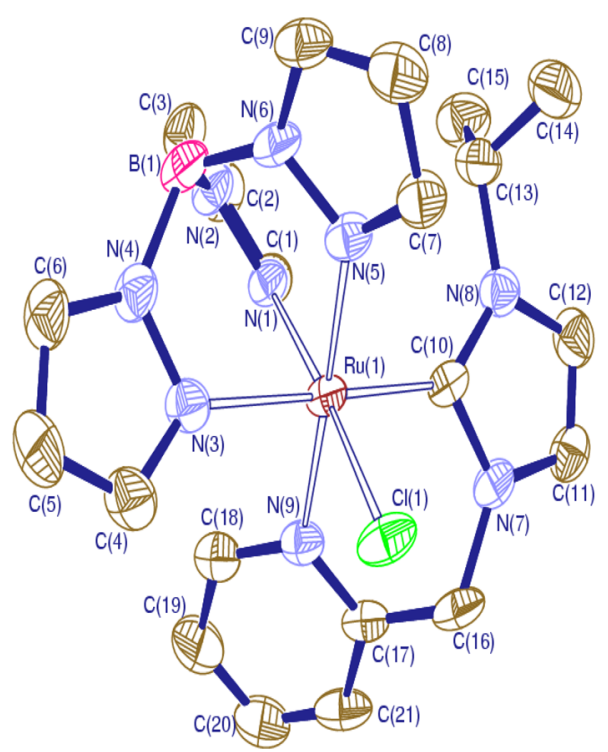

Figure 2. ORTEP diagram for complex $\mathbf{1 b}\left[\mathrm{TpRuCl}\left(\kappa^{2}-C, N-\right.\right.$ picolyl- $\left.\left.{ }^{i{ }^{i r}} \mathrm{I}\right)\right]$ (picolyl- ${ }^{i{ }^{i r} \mathrm{I}}=3$-isopropyl-1-(2-picolyl)imidazol-2-ylidene) with $50 \%$ probability ellipsoids. Hydrogen atoms have been omitted for clarity. Color code: $\mathrm{Ru}$, red; N, blue; C, brown; B, pink; $\mathrm{Cl}$, green.

was obtained, which showed residual silver bromide with the composition $\mathbf{1 b} \cdot 0.35 \mathrm{AgBr}$. Its structure has been determined by $\mathrm{X}$-ray analysis (Figure S1 in Supporting Information).

As far as we know, no structure containing $\mathrm{TpRu}$ and a chelating NHC ligand has been previously described. The octahedral geometry of $\mathrm{Ru}$ in $\mathbf{1 b}$ is distorted with the greatest deviation from linearity in the axis $\mathrm{Cl}(1)-\mathrm{Ru}(1)-\mathrm{N}(1)$, $172.86(9)^{\circ}$, and bond angles between ligands in cis, ranging from $84.35^{\circ}$ to $95.23^{\circ}$. Imidazolyl and pyridyl rings form a dihedral angle of $52.24(23)^{\circ}$. These rings are almost aligned with the pyrazolyl rings trans to them, forming dihedral angles of $10.78(38)^{\circ}$ for the imidazolyl ring and $14.10(38)^{\circ}$ for the pyridyl ring, respectively. The bond lengths corresponding to $\mathrm{Ru}(1)-\mathrm{Cl}(1), 2.4436(11) \AA$, and $\mathrm{Ru}(1)-\mathrm{C}(10), 2.000(5) \AA$, are comparable with those reported for [TpRuClLL'] $(\mathrm{L}=1,3$ bis(2,4,6-trimethylphenyl)-4,5-dihydroimidazol-2-ylidene; $\mathrm{L}^{\prime}=$ 2-ethoxycarbonylbenzylidene). ${ }^{26}$ They are also similar to those found for ruthenium $p$-cymene complexes containing 3-methyl1-(2-picolyl)imidazol-2-ylidene) or 3-methyl-1-(2-picolyl)-4,5dichloroimidazol-2-ylidene) ligands. ${ }^{29} \mathrm{Ru}-\mathrm{N}$ bond lengths increase from 2.046(4) $\AA$ for $\mathrm{N}(1)$ trans to $\mathrm{Cl}(1)$ to 2.131(4) for $\mathrm{N}(3)$ trans to the imidazol-2-ylidene carbon $\mathrm{C}(10)$. This trans influence is also similar to that found for the above cited ruthenium complex $\left[\mathrm{TpRuClLL}^{\prime}\right]^{26}$

The reactivity of the new ruthenium complexes toward small molecules was assessed upon in situ generation of the corresponding 16-electron species via reaction of $1 \mathrm{a}-\mathrm{e}$ with a halide scavenger, $\mathrm{NaBAr}_{4}^{\mathrm{F}}\left(\mathrm{Ar}^{\mathrm{F}}=3,5\right.$-bis(trifluoromethyl)phenyl), in fluorobenzene and in the presence of the appropriate substrate.

Reactivity of $1 \mathrm{a}-\mathrm{e}$ with CO. A fluorobenzene solution of the appropriate $\mathrm{TpRu}\left(\kappa^{2}-C, N\right.$-picolyl-NHC $) \mathrm{Cl}$ precursor, 1ae, and $\mathrm{NaBAr}^{\mathrm{F}}{ }_{4}$ was treated with 1 atm of $\mathrm{CO}$. All complexes reacted irreversibly, generating the expected $\left[\mathrm{TpRu}\left(\kappa^{2}-C, N\right.\right.$ picolyl- $\left.\left.{ }^{R} \mathrm{I}\right) \mathrm{CO}\right]\left[\mathrm{BAr}_{4}^{\mathrm{F}}\right]$ complexes, 2a-e (Scheme 2). The compounds were characterized by ${ }^{1} \mathrm{H} \mathrm{NMR},{ }^{13} \mathrm{C}\left\{{ }^{1} \mathrm{H}\right\} \mathrm{NMR}$, elemental analysis, and IR.

\section{Scheme 2}

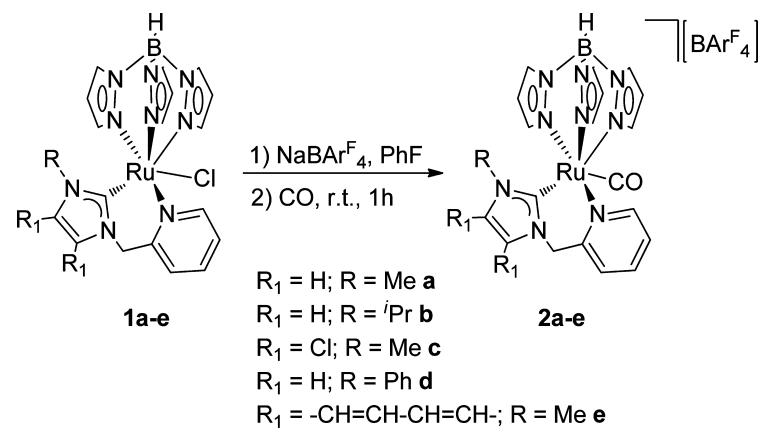

The data shown in Table 1 indicates that each compound displayed a single strong carbonyl absorption band between

Table 1. Selected IR $\left(\nu, \mathrm{cm}^{-1}\right)$ and ${ }^{13} \mathrm{C}\left\{{ }^{1} \mathrm{H}\right\}$ NMR $(\delta$, ppm $)$ Data for Compounds $2 a-e$

\begin{tabular}{cccccc} 
& & IR & & \multicolumn{2}{c}{${ }^{13} \mathrm{C}\left\{{ }^{1} \mathrm{H}\right\}$} \\
\cline { 3 - 3 } \cline { 5 - 6 } entry & complex & $\nu(\mathrm{CO})$ & & $\mathrm{RuC} \equiv \mathrm{O}$ & $\mathrm{C}_{2}-\mathrm{NHC}$ \\
\hline 1 & 2a & 1964 & & 203.0 & 177.5 \\
2 & 2b & 1973 & & 203.2 & 175.2 \\
3 & 2c & 1984 & & 204.0 & 180.4 \\
4 & 2d & 1976 & & 204.6 & 177.0 \\
5 & 2e & 1976 & & 205.9 & 168.6 \\
\hline
\end{tabular}

1964 and $1984 \mathrm{~cm}^{-1}$. In addition, important differences were observed between the donating properties of the picolyl-NHC ligands; particularly, $2 \mathrm{c}$ showed a significantly higher value of stretching frequency (entry 3 ) in comparison with its analogue 2a (entry 1 ). These results can be rationalized by the presence of the two chloro substituents in the imidazol backbone of $2 \mathrm{c}$, which led to a less donating imidazolydene ligand and a more electron deficient ruthenium center. Also, N-wingtip substituents have an influence in the donor properties of picolylNHC ligands, although less pronounced in comparison with the backbone substituents. Particularly, 2a with a methyl group as wingtip showed the lowest CO stretching frequency (entry 1 ), while isopropyl and phenyl (entries 2 and 4 ) derivatives, $\mathbf{2 b}$ and $\mathbf{2 d}$, showed higher stretching frequencies, indicating the stronger $\sigma$ donating power of 3-methyl-1-(2-picolyl)imidazolydene ligand in comparison with its analogues. Furthermore, the coordination of the carbonyl moiety led to a shift to high field of the $\mathrm{C}_{2}$ carbene carbon resonance, as was predicted considering the weakening of the $\mathrm{Ru}-\mathrm{C}_{2}$ bond by the presence of a $\mathrm{CO}$ ligand. However, no significant differences are observed in the ${ }^{13} \mathrm{C}\left\{{ }^{1} \mathrm{H}\right\}$ NMR spectra of the carbonyl complexes, 2a-e, regarding $\mathrm{Ru}-\mathrm{C}_{2}$ and $\mathrm{RuCO}{ }^{13} \mathrm{C}\left\{{ }^{1} \mathrm{H}\right\} \mathrm{NMR}$ chemical shifts. 
Crystals of $\mathbf{2 a}$ and $\mathbf{2 d}$ suitable for X-ray diffraction were obtained after recrystallization from $\mathrm{Et}_{2} \mathrm{O}$ /petroleum ether (1/ $2)$. ORTEP diagrams of $\left[\mathrm{TpRu}\left(\kappa^{2}-C, N\right.\right.$-picolyl- $\left.\left.{ }^{M e} \mathrm{I}\right) \mathrm{CO}\right]$ $\left[\mathrm{BAr}_{4}^{\mathrm{F}}\right], \mathbf{2 a}$, and $\left[\mathrm{TpRu}\left(\kappa^{2}-C, N\right.\right.$-picolyl- $\left.\left.{ }^{\mathrm{Ph}} \mathrm{I}\right) \mathrm{CO}\right]\left[\mathrm{BAr}_{4}^{\mathrm{F}}\right], \mathbf{2} \mathbf{b}$, are displayed in Figures 3 and 4, respectively.

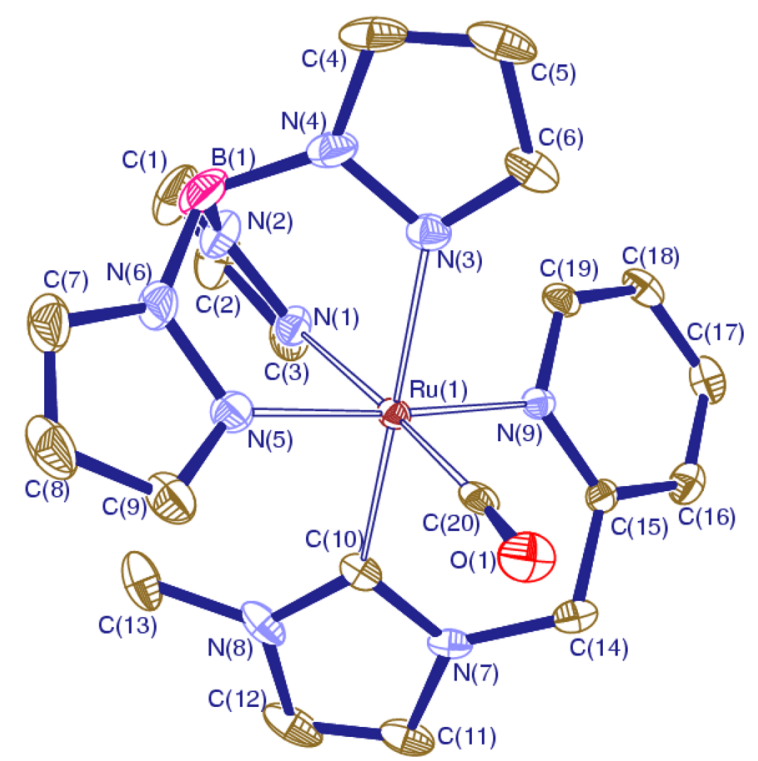

Figure 3. ORTEP diagram of the cation $\left[\mathrm{TpRu}\left(\kappa^{2}-C, N\right.\right.$-picolyl- $\left.{ }^{M e} \mathrm{I}\right)$ $(\mathrm{CO})]^{+}$(picolyl- ${ }^{M e} \mathrm{I}=3$-methyl)1-(2-picolyl)imidazol-2-ylidene) in 2a with $50 \%$ probability ellipsoids. Hydrogen atoms have been omitted for clarity. Color code: Ru, dark red; N, blue; C, brown; B, pink; O, red.

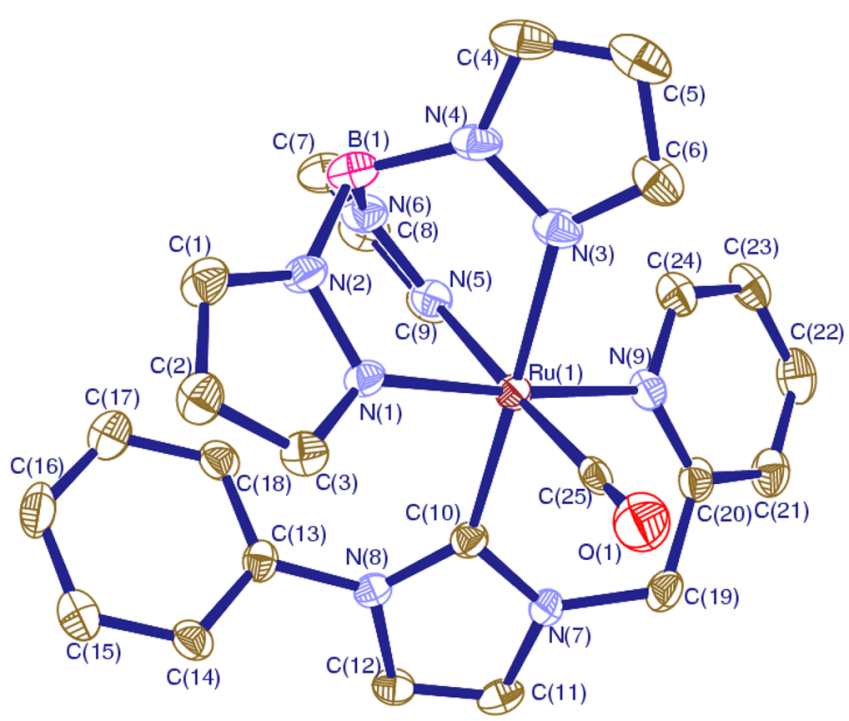

Figure 4. ORTEP diagram of the cation $\left[\mathrm{TpRu}\left(\kappa^{2}-C, N\right.\right.$-picolyl $\left.-{ }^{\mathrm{Ph}} \mathrm{I}\right)$ $(\mathrm{CO})]^{+}$(picolyl- ${ }^{P h} \mathrm{I}=3$-phenyl-1-(2-picolyl)imidazol-2-ylidene) in $2 \mathrm{~d}$ with $50 \%$ probability ellipsoids. Hydrogen atoms have been omitted for clarity. Color code: Ru, dark red; N, blue; C, brown; B, pink; O, red.

As previously shown for the crystal structure of the neutral chlorocomplex, $\mathbf{1 b}$, the octahedron around $\mathrm{Ru}$ is distorted in cationic complexes $\left[\mathrm{TpRu}\left(\kappa^{2}-C, N \text {-picolyl }{ }^{\mathrm{Me}} \mathrm{I}\right)(\mathrm{CO})\right]^{+}, \mathbf{2 a}$, and $\left[\mathrm{TpRu}\left(\kappa^{2}-C, N \text {-picolyl }{ }^{P h} \mathrm{I}\right)(\mathrm{CO})\right]^{+}, \mathbf{2 d}$. The transverse axis to the $\mathrm{C}-\mathrm{Ru}-\mathrm{C}$ plane in $2 \mathrm{a}, \mathrm{N}(5)-\mathrm{Ru}(1)-\mathrm{N}(9) 174.34(11)^{\circ}$, and $2 \mathrm{~d}, \mathrm{~N}(1)-\mathrm{Ru}(1)-\mathrm{N}(9) 173.51(13)$, respectively, show the maximum deviation from linearity in each case. Bond angles between ligands in cis are in the range $85.22(13)-96.55(13)^{\circ}$ for $2 \mathrm{a}$ and $84.28(13)-95.48(14)^{\circ}$ for $2 \mathrm{~d}$. Imidazolyl and pyridyl rings in the chelating NHC ligand form a dihedral angle of $58.68(13)^{\circ}$ for $2 \mathrm{a}$ and $50.45(12)^{\circ}$ for $\mathbf{2 d}$. These rings are more closely aligned with the pyrazolyl rings trans to them for $2 a$, forming dihedral angles of $10.08(25)^{\circ}$ for the imidazolyl ring and $10.22(28)^{\circ}$ for the pyridyl ring, whereas for $2 \mathrm{~d}$, the analogous dihedral angles are $20.52(0.19)^{\circ}$ and $13.93(27)^{\circ}$, respectively. In both compounds, the shortest $\mathrm{Ru}-\mathrm{N}$ bond length corresponds to the $\mathrm{N}$ atom of the pyrazolyl ring opposite to the pyridinic $\mathrm{N}$ atom, $\mathrm{Ru}(1)-\mathrm{N}(5) 2.068(3) \AA$ for $2 \mathrm{a}$ and $\mathrm{Ru}(1)-\mathrm{N}(1) 2.071(3) \AA$ for $2 \mathrm{~d}$. X-ray structures confirmed the IR data analysis conclusions, indicating a CO ligand more strongly bound to the metal in the case of the methyl derivative $2 \mathrm{a}, \mathrm{Ru}(1)-\mathrm{C}(20) 1.866(4) \AA$ than in the phenyl derivative $2 \mathrm{~d}, \mathrm{Ru}(1)-\mathrm{C}(25) 1.920$ (5) Å. Consequently, the $\pi$ backbonding effect is larger in the first case showing a CO bond length of $1.132(5) \AA$, which is in line with the mean value of $1.134(22) \AA$ known for $\mathrm{C} \equiv \mathrm{O}$ ligand bonded to $\mathrm{Ru}^{33}$

Reactivity of $1 \mathrm{a}-\mathrm{e}$ with $\mathrm{N}_{2}$. A solution of the corresponding chloro complex, $\mathbf{1 a - e}$, in fluorobenzene under dinitrogen atmosphere was treated with a halide scavenger, $\mathrm{NaBAr}_{4}^{\mathrm{F}}$. The reactions afforded several nitrogen complexes. It is interesting to note that, upon reaction of $\mathbf{1 a}$ and $\mathrm{NaBAr}_{4}{ }_{4}$ under 1 atm of nitrogen, two dinuclear dinitrogen bridged complexes, $\mathbf{3 a}$ and $\mathbf{3}^{\prime} \mathbf{a}$, were generated (Scheme 3 ). The dinitrogen complexes, $\mathbf{3 a}$ and $\mathbf{3}^{\prime} \mathbf{a}$, are diastereoisomers given the chiral character of the new ruthenium center in the bridged structure. The mixture of diastereoisomers was characterized by ${ }^{1} \mathrm{H},{ }^{13} \mathrm{C}\left\{{ }^{1} \mathrm{H}\right\}$, and $2 \mathrm{D}{ }^{1} \mathrm{H},{ }^{13} \mathrm{C}$ NMR spectra, elemental analysis, $\mathrm{IR}$, and Raman spectroscopy. Complexes $\mathbf{3 a}$ and $\mathbf{3}^{\prime} \mathbf{a}$ were isolated as a mixture in a reproducible manner as the only species resulting from the reaction, in ca. $91 \%$ yield. The presence of two nonequivalent ruthenium centers is evidenced by the duplication of all proton and carbon signals in the NMR spectra corresponding to Tp and picolyl- ${ }^{M e} \mathrm{I}$ ligands. However, both complexes are very similar in terms of chemical shifts, particularly the $\mathrm{Ru}-\mathrm{C}_{2}-\mathrm{NHC}$ carbon bonds in the ${ }^{13} \mathrm{C}\left\{{ }^{1} \mathrm{H}\right\}$ NMR spectrum appeared at 180.5 and 180.4 ppm, respectively. Also, it is very interesting that $\mathbf{3 a}$ and $\mathbf{3}^{\prime} \mathbf{a}$ must be almost identical in stability because they are found as a $1 / 1$ mixture, as evidenced by the ${ }^{1} \mathrm{H}$ NMR integrals.

Crystals of diastereomer $3^{\prime}$ a were obtained after recrystallization from $\mathrm{Et}_{2} \mathrm{O} /$ petroleum ether (1/2). Although all the crystals evaluated proved to be racemic twinning, a structure was obtained by analysis as the twin of X-ray diffraction data in monoclinic space group $P n$. ORTEP diagram of diastereomer $\mathbf{3}^{\prime} \mathbf{a}$ is displayed in Figure 5. To the best of our knowledge, $\mathbf{3}^{\prime} \mathbf{a}$ is the first $\mathrm{TpRu}$ nitrogen bridged complex synthesized using NHCs as ligands.

The structure of $\mathbf{3}^{\prime} \mathbf{a}$ shows the ruthenium atoms in a distorted octahedral geometry, with the largest deviation from linearity in the $\mathrm{N}-\mathrm{Ru}-\mathrm{N} \equiv \mathrm{N}-\mathrm{Ru}-\mathrm{N}$ unit, $\mathrm{N}(5)-\mathrm{Ru}(1)-$ $\mathrm{N}(10) 171.6(2)^{\circ}$ and $\mathrm{N}(11)-\mathrm{Ru}(2)-\mathrm{N}(16) 173.1(2)^{\circ}$. Bond angles between ligands in cis are in the range 85.2(2)-96.3(3) ${ }^{\circ}$ for $\mathrm{Ru}(1)$ and $85.7(3)-95.4(3)^{\circ}$ for $\mathrm{Ru}(2)$. Imidazolyl and pyridyl rings in the chelating NHC ligands form dihedral angles of $53.67(38)^{\circ}$ and $62.07(33)^{\circ}$, respectively. The dihedral angles for the alignment between the imidazolyl rings and the pyrazolyl rings in trans to them are $11.07(87)^{\circ}$ and $7.92(81)^{\circ}$, whereas the analogous angles for the pyridyl rings are $8.53(53)^{\circ}$ and $6.01(49)^{\circ}$. The dinitrogen bridge ligand 
Scheme 3

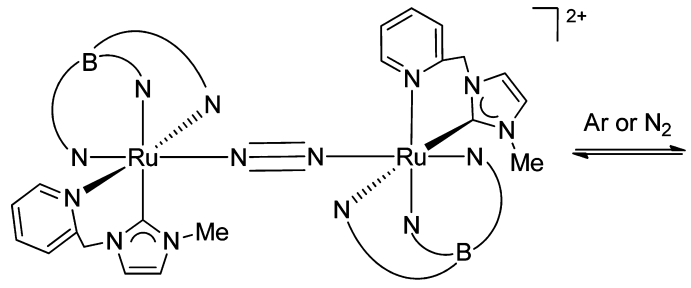

3a $\Delta \Delta, \Lambda \Lambda$

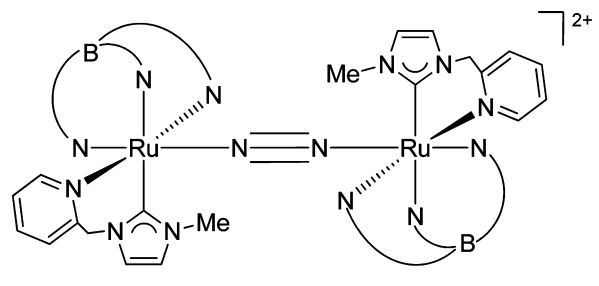

3'a $\Delta \Lambda, \Lambda \Delta$

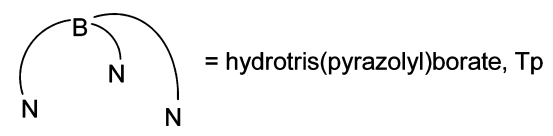

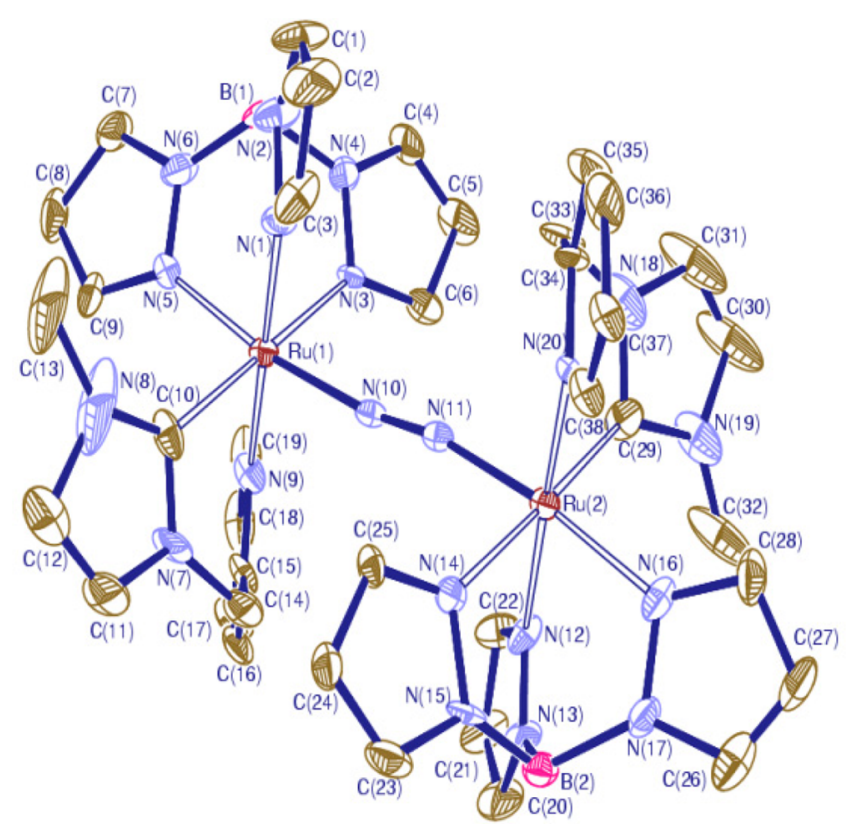

Figure 5. ORTEP diagram for $\left[\left\{\mathrm{TpRu}\left(\kappa^{2}-C, N \text {-picolyl- }{ }^{M e} \mathrm{I}\right)\right\}_{2}\left(\mu-\mathrm{N}_{2}\right)\right]^{2+}$ (picolyl- ${ }^{M e} \mathrm{I}=3$-methyl-1-(2-picolyl)imidazol-2-ylidene) in $\mathbf{3}^{\prime} \mathbf{a}$ with $30 \%$ probability ellipsoids. Hydrogen atoms have been omitted for clarity. Color code: $\mathrm{Ru}$, dark red; N, blue; C, brown; B, pink.

shows $\mathrm{Ru}-\mathrm{N}$ bond lengths of 1.971(6) and 1.884(6) A. These results are similar to the values found for the related complex $\left[\left\{\mathrm{TpRuCl}\left(\mathrm{PCy}_{3}\right)\right\}_{2}\left(\mu-\mathrm{N}_{2}\right)\right] .^{28}$ Also, the $\mathrm{N}-\mathrm{N}$ bond length, 1.124(5) $\AA$, matches the mean value of 1.125(14) $\AA$ found for $\mathrm{N} \equiv \mathrm{N}$ ligand bridging two $\mathrm{Ru}$ atoms. ${ }^{33}$ Like in the case of the previously reported structures of $\mathbf{1 b}, \mathbf{2} \mathbf{a}$, and $\mathbf{2 d}$, the carbenic $\mathrm{C}$ exhibits the largest trans influence, while the shortest $\mathrm{Ru}-\mathrm{N}$ distances, 2.035(6) $\AA$ for $\mathrm{Ru}(1)$ and 2.081(6) $\AA$ for $\mathrm{Ru}(2)$, correspond to the $\mathrm{N}$ atoms opposite to $\mathrm{N}_{2}$ bridge ligand.

Consistently with the centrosymmetrical nature of the binuclear dinitrogen complex cations, the IR spectra of the mixture lack a band attributable to $\nu\left(\mathrm{N}_{2}\right)$. However, the mixture displayed activity in Raman, showing a medium-weak band at $2091 \mathrm{~cm}^{-1}$; considering the similarities in both structures, it is likely to find a coincidental value for $\nu\left(\mathrm{N}_{2}\right)$. The Raman band can be assigned to the symmetric $\nu\left(\mathrm{N}_{2}\right)$ mode, similar to those found for the symmetrical binuclear complexes $\left[\left\{\left(\eta^{5}-\mathrm{C}_{5} \mathrm{H}_{5}\right) \mathrm{Ru}(\text { dippe })\right\}_{2}\left(\mu-\mathrm{N}_{2}\right)\right]^{2+}\left(2050 \mathrm{~cm}^{-1}\right),{ }^{19 \mathrm{~d}}$ $\left[\left\{\left(\eta^{5}-\mathrm{C}_{5} \mathrm{H}_{5}\right) \mathrm{Ru}\left(\mathrm{PEt}_{3}\right)\right\}_{2}\left(\mu-\mathrm{N}_{2}\right)\right]^{2+}\left(2064 \mathrm{~cm}^{-1}\right){ }^{19 \mathrm{~d}}[\{\mathrm{Ru}-$ $\left.\left.(\text { acac })_{2}\left(\mathrm{P}^{i} \operatorname{Pr}_{3}\right)\right\}_{2}\left(\mu-\mathrm{N}_{2}\right)\right]\left(2089 \mathrm{~cm}^{-1}\right),^{34}\left[\left\{\mathrm{Ru}\left(\mathrm{NH}_{3}\right)_{5}\right\}_{2}(\mu\right.$ -
$\left.\left.\left.\mathrm{N}_{2}\right)\right]^{4+}\left(2100 \mathrm{~cm}^{-1}\right)\right)^{35}$ and $\left[\left\{\mathrm{Ru}\left(\mathrm{H}_{2} \mathrm{O}\right)_{5}\right\}_{2}\left(\mu-\mathrm{N}_{2}\right)\right]^{4+}(2080$ $\left.\mathrm{cm}^{-1}\right){ }^{36}$

In addition, $\mathbf{3 a}$ and $\mathbf{3}^{\prime} \mathbf{a}$ demonstrated to be moderately stable, for days, in the solid state toward air exposure. Furthermore, ${ }^{1} \mathrm{H}$ NMR spectra experiments were performed under argon and nitrogen atmosphere, to evaluate if an equilibrium with the terminal mononuclear dinitrogen complex was observed, according to eq 1 or 2 , depending on the case. However, no evidence of the presence of a third species was found. In solution, the mixture of isomers remained unchanged. Also, freeze-pump-thaw degassing experiments showed no evidence of generation of unsaturated species or nitrogen loss.

$$
\begin{aligned}
& {\left[\left\{\operatorname{TpRu}\left(\kappa^{2}-C, N-\text { picolyl }-{ }^{R} \mathrm{I}\right)\right\}_{2}\left(\mu-\mathrm{N}_{2}\right)\right]^{2+}} \\
& \stackrel{\operatorname{Ar}}{\rightleftharpoons}\left[\mathrm{TpRu}\left(\kappa^{2}-C, N-\text { picolyl }-{ }^{R} \mathrm{I}\right)\left(N_{2}\right)\right]^{+} \\
& \quad+\left[\mathrm{TpRu}\left(\kappa^{2}-C, N-\text { picolyl }-{ }^{R} \mathrm{I}\right)\right]^{+} \\
& \quad\left[\left\{\mathrm{TpRu}\left(\kappa^{2}-C, N-\text { picolyl }-{ }^{R} \mathrm{I}\right)\right\}_{2}\left(\mu-\mathrm{N}_{2}\right)\right]^{2+}+\mathrm{N}_{2} \\
& \quad \rightleftharpoons 2\left[\mathrm{TpRu}\left(\kappa^{2}-C, N-\text { picolyl }-{ }^{R} \mathrm{I}\right)\left(\mathrm{N}_{2}\right)\right]^{+}
\end{aligned}
$$

Exposure of a fluorobenzene solution of $\mathbf{1 b}$ and $\mathrm{NaBAr}^{\mathrm{F}}{ }_{4}$ to 1 atm of $\mathrm{N}_{2}$ at room temperature revealed the formation of the corresponding binuclear dinitrogen bridged complex, $[\{\mathrm{TpRu}-$ $\left(\kappa^{2}-C, N\right.$-picolyl- $\left.\left.\left.{ }^{i{ }^{i} r} \mathrm{I}\right)\right\}_{2}\left(\mu-\mathrm{N}_{2}\right)\right]\left[\mathrm{BAr}^{\mathrm{F}}{ }_{4}\right]_{2}, 3 \mathrm{~b}$. The new complex was isolated in ca. $93 \%$ yield as yellow crystals. Complex $\mathbf{3 b}$ was characterized using ${ }^{1} \mathrm{H}$ and ${ }^{13} \mathrm{C}\left\{{ }^{1} \mathrm{H}\right\}$ NMR, IR, Raman, and elemental analysis. In contrast to $\mathbf{1 a}$, the isopropyl derivative, $\mathbf{l b}$, led to a single isomer as evidenced by the NMR spectra, where no duplication of signals is observed. A distinctive $\mathrm{Ru}-$ $\mathrm{C}_{2}-\mathrm{NHC}$ carbon resonance was observed at $178.3 \mathrm{ppm}$, in addition to a single characteristic pair of methylene group doublets in the ${ }^{1} \mathrm{H}$ NMR spectrum at 4.56 and $4.23 \mathrm{ppm}$, respectively. The NMR spectrum of $\mathbf{3 b}$ was recorded under argon and nitrogen atmospheres; in neither case, the dissociation equilibrium as described in eq 1 or 2 was evident. The occurrence of one diastereoisomer can be explained by the larger steric effect of the isopropyl wingtip group, which must favor only one structure. The recrystallization of $3 \mathbf{b}$ proved to be very challenging because despite working with numerous solvent mixtures, in no case were the crystals obtained large enough to perform an X-ray diffraction study. Besides, $\nu\left(\mathrm{N}_{2}\right)$ band of $\mathbf{3 b}$ in the solid state and in solution is inactive in the IR, but a medium-weak absorption band was observed in the Raman spectrum at $2093 \mathrm{~cm}^{-1}$, as expected for a centrosymmetrical $\nu\left(\mathrm{N}_{2}\right)$ band. Also, elemental analysis is consistent with the formation of the dinitrogen bridged complex. 
In the case of $\mathbf{1 c}$, we were unable to synthesize the dinitrogen derivative. Many attempts of the reaction of the fluorobenzene solution of $1 \mathrm{c}$ in the presence of $\mathrm{NaBAr}_{4}^{\mathrm{F}}$, at room temperature, low temperatures, and with different reaction times, were completed and proved to be unsuccessful. ${ }^{1} \mathrm{H}$ NMR spectra of the reaction mixtures showed evidence of decomposition products and the presence of some paramagnetic impurities in all cases. However, we continue to study the influence of picolyl-NHC ligands in the coordination of dinitrogen to the new $\mathrm{TpRu}$ fragment. The ruthenium complex bearing a phenyl group in the imidazolydene ligand, 1d, was the next substrate and the obtained results were unexpected. ${ }^{1} \mathrm{H}$ NMR spectrum of the reaction mixture showed a mixture of three complexes, as evidenced by the triple set of doublets corresponding to the methylene bridged carbons of the picolyl- ${ }^{P h}$ I ligands, as observed in Figure 6. It was plausible to

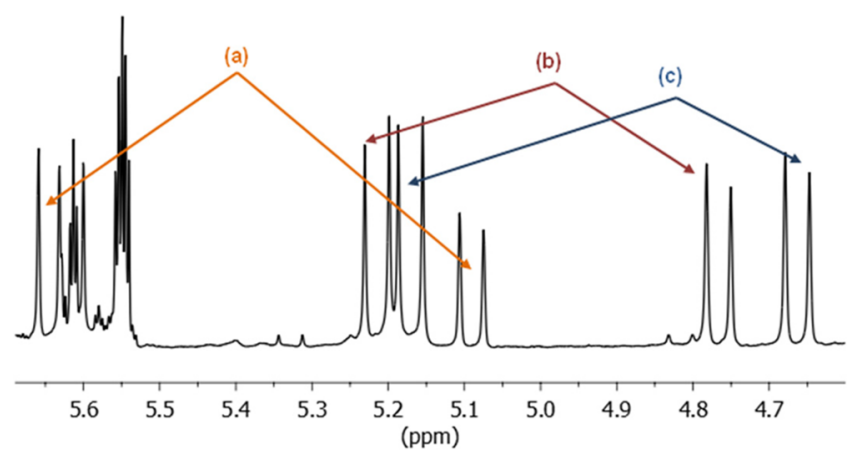

Figure 6. ${ }^{1} \mathrm{H}$ NMR $\left(\delta, \mathrm{CD}_{3} \mathrm{NO}_{2}\right)$ spectrum of the reaction mixture under dinitrogen before recrystallization: (a) mononuclear $\left[\mathrm{TpRu}\left(\kappa^{2}\right.\right.$ $C, N$-picolyl- $\left.\left.{ }^{P h} \mathrm{I}\right)\left(\mathrm{N}_{2}\right)\right]^{+}, 3^{\prime \prime} \mathrm{d}$; (b) $3 \mathrm{~d}$; and (c) $3^{\prime} \mathrm{d}$.

assume that two compounds in the mixture corresponded to the dinitrogen bridged diastereoisomers, $3 \mathbf{d}$ and $\mathbf{3}^{\prime} \mathbf{d}$, and the third species could be the mononuclear $\mathrm{TpRu}$ nitrogen complex, $3^{\prime \prime} \mathrm{d}$ (Scheme 4). The IR band corresponding to the asymmetrical $\nu\left(\mathrm{N}_{2}\right)$ stretching at $2166 \mathrm{~cm}^{-1}$ confirmed the presence of a mononuclear terminal dinitrogen complex, 3 "d, as part of the mixture.

However, the dinitrogen bridged complex, $3^{\prime} \mathrm{d}$, was obtained almost quantitatively as yellow crystals after recrystallization. The IR $\nu\left(\mathrm{N}_{2}\right)$ band was inactive in line with a centrosymmetrical complex, and in contrast to methyl and isopropyl derivatives cases, attempts of recording Raman spectra of $\mathbf{3}^{\prime} \mathbf{d}$ were unsuccessful due to the thermal decomposition of the product by the laser. Crystals of $3^{\prime} \mathrm{d}$ suitable for X-ray diffraction studies were obtained from $\mathrm{Et}_{2} \mathrm{O}$ /petroleum ether $(1 / 2)$. ORTEP diagram of $\left[\left\{\mathrm{TpRu}\left(\kappa^{2}-C, N \text {-picolyl- }{ }^{P h} \mathrm{I}\right)\right\}_{2}(\mu\right.$ $\left.\left.\mathrm{N}_{2}\right)\right]\left[\mathrm{BAr}_{4}^{\mathrm{F}}\right]_{2}$ complex, $\mathbf{3}^{\prime} \mathbf{d}$, is displayed in Figure 7 .

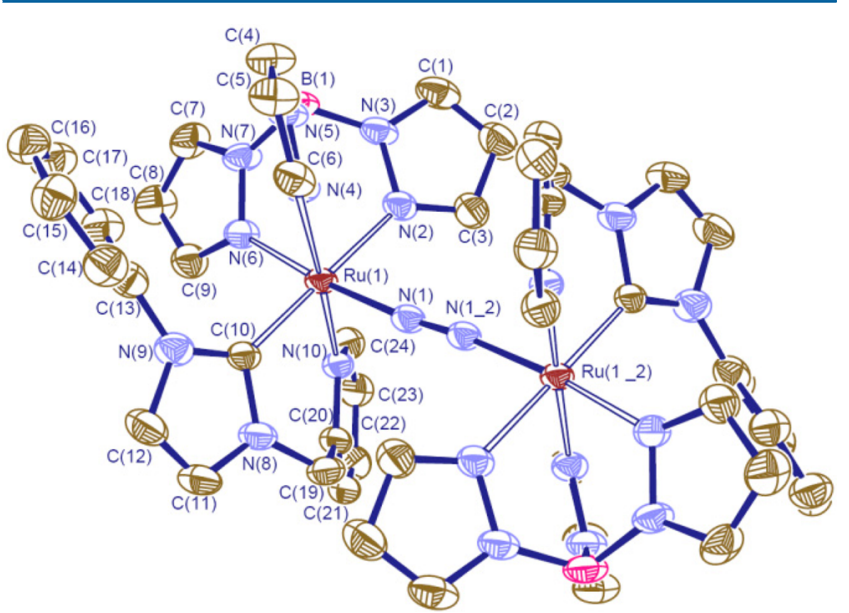

Figure 7. ORTEP diagram of the cation $\left[\left\{\mathrm{TpRu}\left(\kappa^{2}-C, N\right.\right.\right.$-picolyl- $\left.\left.\left.{ }^{P h} \mathrm{I}\right)\right\}_{2}\left(\mu-\mathrm{N}_{2}\right)\right]^{2+} \quad$ picolyl- ${ }^{P h} \mathrm{I}=3$-phenyl-1-(2-picolyl)imidazol-2ylidene) in $3^{\prime} \mathbf{d}$ with $50 \%$ probability ellipsoids. Hydrogen atoms have been omitted for clarity. Color code: $\mathrm{Ru}$, dark red; N, blue; $\mathrm{C}$, brown; B, pink.

Since the asymmetric unit contains half of the cation $\left[\left\{\operatorname{TpRu}\left(\kappa^{2}-C, N \text {-picolyl- }{ }^{P h} \mathrm{I}\right)\right\}_{2}\left(\mu-\mathrm{N}_{2}\right)\right]^{2+}$, the environment of

\section{Scheme 4}

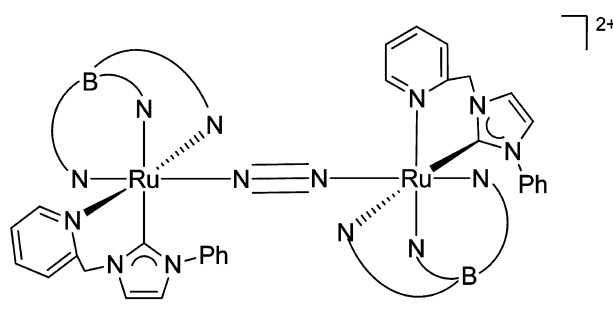

3d $\Delta \Delta, \Lambda \Lambda$

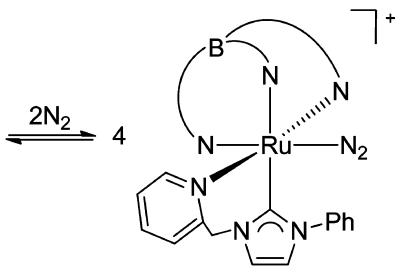

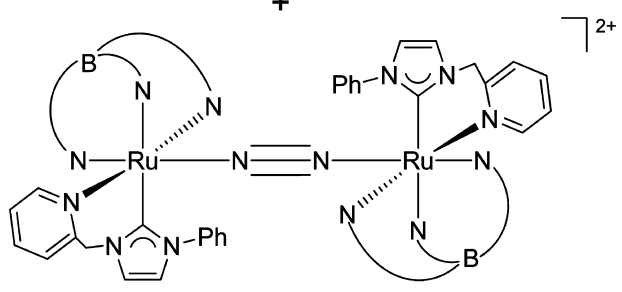

3"d

$\mathbf{3}^{\prime} \mathbf{d} \Delta \Lambda, \Lambda \Delta$

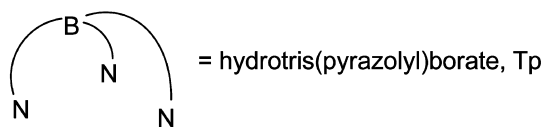


Scheme 5

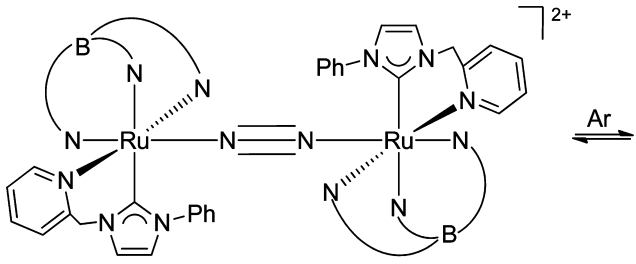

$\mathbf{3}^{\prime} \mathbf{d} \Delta \Lambda, \Lambda \Delta$

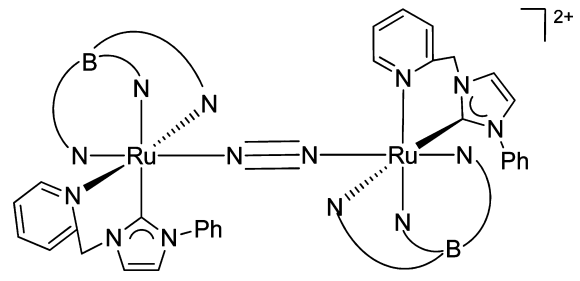

3d $\Delta \Delta, \Lambda \Lambda$

= hydrotris $($ pyrazolyl)borate, $\mathrm{Tp}$

one $\mathrm{Ru}$ atom is repeated by symmetry. Like previously described crystal structures in this work, $3^{\prime} \mathbf{d}$ shows ruthenium in a distorted octahedral geometry. As in complex $3^{\prime} \mathbf{a}$, the largest deviation from linearity is found in the $\mathrm{N}-\mathrm{Ru}-\mathrm{N} \equiv \mathrm{N}-$ $\mathrm{Ru}-\mathrm{N}$ unit, $\mathrm{N}(1)-\mathrm{Ru}(1)-\mathrm{N}(6) \quad 173.59(14)^{\circ}$. Bond angles between ligands in cis are in the range 85.15(14)-95.13(15) ${ }^{\circ}$. Imidazolyl and pyridyl rings in the chelating NHC ligands form a dihedral angle of $47.08(18)^{\circ}$. The dihedral angle for the alignment between the imidazolyl ring and the pyrazolyl ring in trans to it is $18.81(11)^{\circ}$, whereas the analogous angle for the pyridyl ring is $13.14(20)^{\circ}$. The dinitrogen bridge ligand binds to $\mathrm{Ru}$ with a bond length of $1.941(3) \AA$. All these values are comparable with those found for $3^{\prime}$ a. Also, the carbenic $C$ exhibits the largest trans influence, $\mathrm{Ru}(1)-\mathrm{N}(2)$ 2.126(4) $\AA$, while the shortest $\mathrm{Ru}-\mathrm{N}$ distance, $\mathrm{Ru}(1)-\mathrm{N}(6)$ 2.058(3) $\AA$, corresponds to the $\mathrm{N}$ atom opposite to $\mathrm{N}_{2}$ bridge ligand. However, in contrast to $3^{\prime} \mathrm{a}$, the value of $1.103(6) \AA \AA$ for the N$\mathrm{N}$ bond length is in the lower quartile for the reported $\mathrm{N} \equiv \mathrm{N}$ ligand bridging two $\mathrm{Ru}$ atoms. ${ }^{33}$

The NMR spectra of a freshly prepared solution of $3^{\prime} \mathbf{d}$ yellow crystals recorded under argon atmosphere showed the presence of approximately $91 \%$ of this diastereoisomer. The characteristic signal corresponding to the $\mathrm{Ru}-\mathrm{C}_{2}-\mathrm{NHC}$ carbon atom appeared at $179.8 \mathrm{ppm}$, and the methylene bridge protons appeared as the expected pair of doublets at 4.60 and $4.18 \mathrm{ppm}$, respectively. However, in the course of $24 \mathrm{~h}$ at room temperature, an isomerization process to an equivalent mixture of diastereoisomers was observed (Scheme 5). The appearance of another diastereoisomer was confirmed by the decreasing of the ${ }^{1} \mathrm{H}$ NMR signals corresponding to $\mathbf{3}^{\prime} \mathbf{d}$ and the formation of the new complex $3 \mathrm{~d}$ (Figure 8).

When the NMR sample of $\mathbf{3}^{\prime} \mathbf{d}$ crystals was prepared under $\mathrm{N}_{2}$ atmosphere, three species were detected, as in the case of the reaction mixture, showing the presence of both diastereoisomers and a third compound, the mononuclear dinitrogen complex, $3^{\prime \prime} \mathrm{d}$. This behavior can be rationalized considering the process under nitrogen as dissociation equilibrium, according to eq 2 . The ${ }^{1} \mathrm{H}$ NMR spectrum showed three typical sets of methylene bridged doublets (Figure 6). Also, the ${ }^{13} \mathrm{C}\left\{{ }^{1} \mathrm{H}\right\}$ NMR spectrum showed three signals corresponding to $\mathrm{Ru}-\mathrm{C}_{2}-\mathrm{NHC}$ chemicals shifts at 179.9, 179.8, and $190.2 \mathrm{ppm}$, belonging to $\mathbf{3 d}, \mathbf{3}^{\prime} \mathbf{d}$, and $\mathbf{3}^{\prime \prime} \mathrm{d}$, respectively. Also, the NMR sample generated under nitrogen atmosphere was freeze-pump-thaw degassed and placed under argon to record the ${ }^{1} \mathrm{H}$ NMR spectra again. In this case, no changes in the ${ }^{1} \mathrm{H}$ NMR spectrum of the mixture were observed. When the sample prepared under argon was freezepump-thaw degassed and exposed to 1 atm of nitrogen, the equilibrium between dinitrogen bridged complexes and the (a)

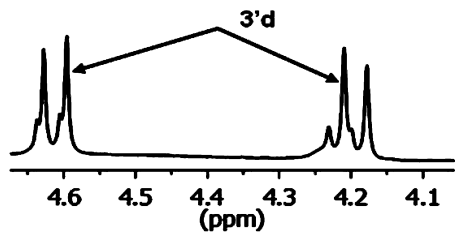

(b)

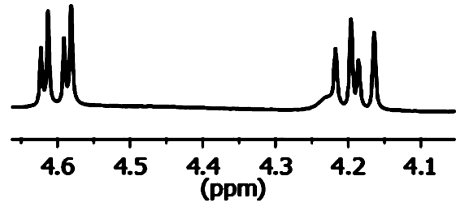

(c)

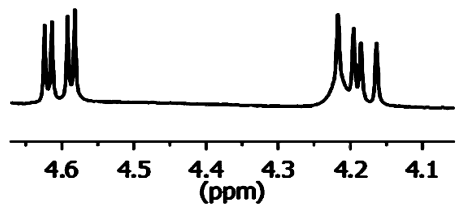

Figure 8. ${ }^{1} \mathrm{H}$ NMR $\left(\delta, \mathrm{CD}_{2} \mathrm{Cl}_{2}\right)$ spectra recorded at different times for the isomerization equilibrium, $\mathbf{3}^{\prime} \mathbf{d} \rightleftharpoons \mathbf{3 d}$ : (a) $30 \mathrm{~min}$; (b) $12 \mathrm{~h}$; and (c) $24 \mathrm{~h}$.

mononuclear dinitrogen complex was reached upon several hours. The equilibrium constant $K_{\text {eq }}$ for the process described in eq 2 and its dependence with temperature has been determined by measuring the concentration of $3 \mathrm{~d}, 3^{\prime} \mathrm{d}$, and $3^{\prime \prime} \mathrm{d}$ in a nitromethane- $d_{3}$ solution under dinitrogen at different temperatures, ranging from -15 to $30{ }^{\circ} \mathrm{C}$. This led to a value of $K_{\text {eq }}=3.4$ at $25^{\circ} \mathrm{C}$. A van't Hoff plot (Figure S2 in Supporting Information) allowed the calculation of $\Delta H^{\circ}$ and $\Delta S^{\circ}$ for the process, and the corresponding values are $4.6 \pm 0.2 \mathrm{~kJ} \mathrm{~mol}^{-1}$ and $27 \pm 1 \mathrm{~J} \mathrm{~mol}^{-1} \mathrm{~K}^{-1}$, respectively. These data suggest that the reaction in eq 2 is entropy driven, and therefore, at high temperatures, the equilibrium favors the formation of the mononuclear dinitrogen complex, $3^{\prime \prime} \mathrm{d}$, whereas the dinitrogen dimers formation, $\mathbf{3 d}$ and $\mathbf{3}^{\prime} \mathbf{d}$, is favored by lowering the temperature.

It is interesting that one isomer, $\mathbf{3}^{\prime} \mathrm{d}$, crystallized preferentially and that, in solution under dinitrogen atmosphere, it slowly transformed into a mixture of diastereoisomers, $\mathbf{3 d}$ and $3^{\prime} \mathrm{d}$, and the mononuclear dinitrogen complex, $3^{\prime \prime} \mathrm{d}$, via a dissociation equilibrium. Similar dissociation patterns of bridging dinitrogen compounds have been observed for a ruthenium(II) complex, cis- $\left[\left\{\mathrm{Ru}(\mathrm{acac})_{2}\left(\mathrm{P}^{i} \mathrm{Pr}_{3}\right)\right\}_{2}\left(\mu-\mathrm{N}_{2}\right)\right],{ }^{34}$ and an osmium(II) complex, cis-[\{OrCl(bipy) $\left.\}_{2}\left(\mu-\mathrm{N}_{2}\right)\right],^{37}$ although no mononuclear species were detected in those cases. However, the nickel $(0)$ complex, $\left[\left\{\mathrm{Ni}\left(\mathrm{PCy}_{3}\right)_{2}\right\}_{2}\left(\mu-\mathrm{N}_{2}\right)\right]$, 
dissociation equilibrium allowed the detection of the mononuclear species, $\left[\mathrm{Ni}\left(\mathrm{PCy}_{3}\right)_{2}\left(\mathrm{~N}_{2}\right)\right]$, by IR spectroscopy. ${ }^{38}$

The benzoimidazol derivative, $\mathbf{1 e}$, reactivity toward nitrogen proved to be similar to the $1 \mathbf{d}$ analogue. The reaction of the fluorobenzene solution of $1 \mathrm{e}$ and $\mathrm{NaBAr}^{\mathrm{F}}{ }_{4}$ under $1 \mathrm{~atm}$ of $\mathrm{N}_{2}$ generated a mixture of the diastereoisomers $\left[\left\{\mathrm{TpRu}\left(\kappa^{2}-C, N\right.\right.\right.$ picolyl $\left.\left.\left.{ }^{M e} \mathrm{BI}\right)\right\}_{2}\left(\mu-\mathrm{N}_{2}\right)\right]^{2+}, 3 \mathbf{e}$ and $\mathbf{3}^{\prime} \mathbf{e}$, corresponding to the nitrogen bridged complexes, in addition to the mononuclear terminal nitrogen compound $\left[\mathrm{TpRu}\left(\kappa^{2}-C, N\right.\right.$-picolyl $\left.-{ }^{M e} \mathrm{BI}\right)$ $\left.\left(\mathrm{N}_{2}\right)\right]^{+}, 3^{\prime \prime}$ e. The mixture was characterized by NMR and IR spectroscopy. Particularly, the IR spectrum of the solid obtained from the reaction showed a strong absorption IR band at $2172 \mathrm{~cm}^{-1}$, indicating the presence of $\nu\left(\mathrm{N}_{2}\right)$ stretching frequencies as a consequence of the occurrence of the mononuclear complex, $3^{\prime \prime}$ e. The ${ }^{1} \mathrm{H}$ NMR spectrum showed three typical sets of methylene bridged doublets as shown in Figure 9. Also, the ${ }^{13} \mathrm{C}\left\{{ }^{1} \mathrm{H}\right\}$ NMR spectrum showed three

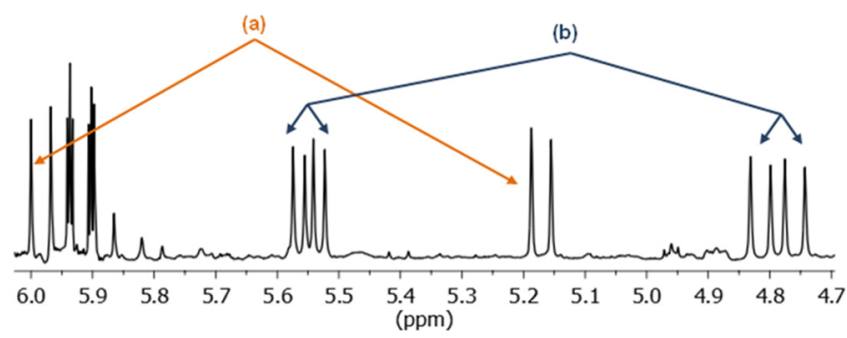

Figure 9. ${ }^{1} \mathrm{H}$ NMR $\left(\delta, \mathrm{CD}_{3} \mathrm{NO}_{2}\right)$ spectrum of the reaction product: (a) mononuclear $\left[\mathrm{TpRu}\left(\kappa^{2}-C, N \text {-picolyl- }{ }^{\mathrm{Me}} \mathrm{BI}\right)\left(\mathrm{N}_{2}\right)\right]^{+}, 3^{\prime \prime}$ e; (b) $3 \mathrm{e}$ and 3'e.

signals corresponding to $\mathrm{Ru}-\mathrm{C}_{2}-\mathrm{NHC}$ chemicals shifts at 195.8, 195.9, and $205.9 \mathrm{ppm}$, belonging to $\mathbf{3 e}, \mathbf{3}^{\prime} \mathbf{e}$, and $\mathbf{3}^{\prime \prime} \mathbf{e}$, respectively. Attempts of recording the Raman spectrum were unsuccessful due to sample decomposition by the laser.

The equilibrium constant $K_{\text {eq }}$ for the process described in eq 2 using the benzoimidazolydene derivative and its dependence with temperature has been determined by measuring the concentration of $3 \mathbf{e}, \mathbf{3}^{\prime} \mathbf{e}$, and $3^{\prime \prime} \mathbf{e}$ in a nitromethane- $d_{3}$ solution under dinitrogen at different temperatures, ranging from -15 to $30^{\circ} \mathrm{C}$. This led to a value of $K_{\text {eq }}=2.2$ at $25^{\circ} \mathrm{C}$. A van't Hoff plot (Figure S3 in Supporting Information) allowed the calculation of $\Delta H^{\circ}$ and $\Delta S^{\circ}$ for the process and the corresponding values are $6.8 \pm 0.4 \mathrm{~kJ} \mathrm{~mol}^{-1}$ and $30 \pm 2 \mathrm{~J}$ $\mathrm{mol}^{-1} \mathrm{~K}^{-1}$, respectively. These data suggest, as in the case of the phenyl derivative, that the reaction is entropy driven favoring the formation of the mononuclear dinitrogen complex, 3 "e, at high temperatures.

No major differences were observed in terms of the donor properties of the picolyl-NHC ligands on the TpRu metal center, based on the $\mathrm{CO}$ stretching values of the carbonyl derivatives (Table 1). However, it is clear that the reactivity toward nitrogen is dramatically influenced by the picolyl-NHC ligands used. The same reaction conditions led to an equimolar mixture of nitrogen bridging diastereoisomers, as was the case for $\mathbf{1 a}$, or a single diastereoisomer when $\mathbf{1 b}$ was used as starting material. Complex 1c did not allow the isolation of any dinitrogen derivative, while $1 \mathbf{d}$ and $1 \mathrm{e}$ led to a mixture of the bridging diastereoisomers and the terminal nitrogen mononuclear complex in solution. It is likely that steric effects play a big role, when the generation of the nitrogen derivatives takes place. Furthermore, the occurrence of different diastereoisomers can be justified by the formation of prochiral pentacoordinated 16-electron species with a two legs piano stool geometry, $\left[\mathrm{TpRu}\left(\kappa^{2}-C, N \text {-picolyl-NHC }\right)\right]^{+}$. Steric effects may affect the equilibrium of the unsaturated species, which implies that, for different imidazol wingtips, it is unlikely to obtain the same mixture of complexes. The case of the benzoimidazol derivative is particular, considering the rigidity of the ligand benzoimidazolydene in comparison with the imidazolydene analogue, which might explain the differences observed in terms of the generated dinitrogen complexes. Also, it is interesting that these nitrogen derivatives are labile and may be used as catalysts in several transformations. We are currently investigating the catalytic applications of these new complexes.

Additionally, our group has reported the reactivity of $\mathrm{Tp}-$ ruthenium(II) phosphine complexes, but no similar equilibrium behavior was observed because the terminal mononuclear derivatives were obtained in all cases. ${ }^{39}$ Only when cyclopentadienyl ruthenium(II) phosphine complexes were used as starting products some dinitrogen bridging complexes were generated. ${ }^{19 \mathrm{~d}}$

Reactivity of Dinitrogen Complexes $3 a, 3^{\prime} a$, and $3 b$ with $\mathrm{CO}$ and $\mathrm{CH}_{3} \mathrm{CN}$. The reactivity of $3 \mathrm{a}, 3^{\prime} \mathrm{a}$, and $3 \mathrm{~b}$ toward stronger donor ligands such as $\mathrm{CO}$ or $\mathrm{CH}_{3} \mathrm{CN}$ led to the corresponding substitution derivatives, $\mathbf{2} \mathbf{a}-\mathbf{b}$ and $\mathbf{4 a - b}$ (Scheme 6). The ${ }^{1} \mathrm{H}$ and ${ }^{13} \mathrm{C}\left\{{ }^{1} \mathrm{H}\right\}$ NMR spectra of $\mathbf{4 a - b}$

Scheme 6

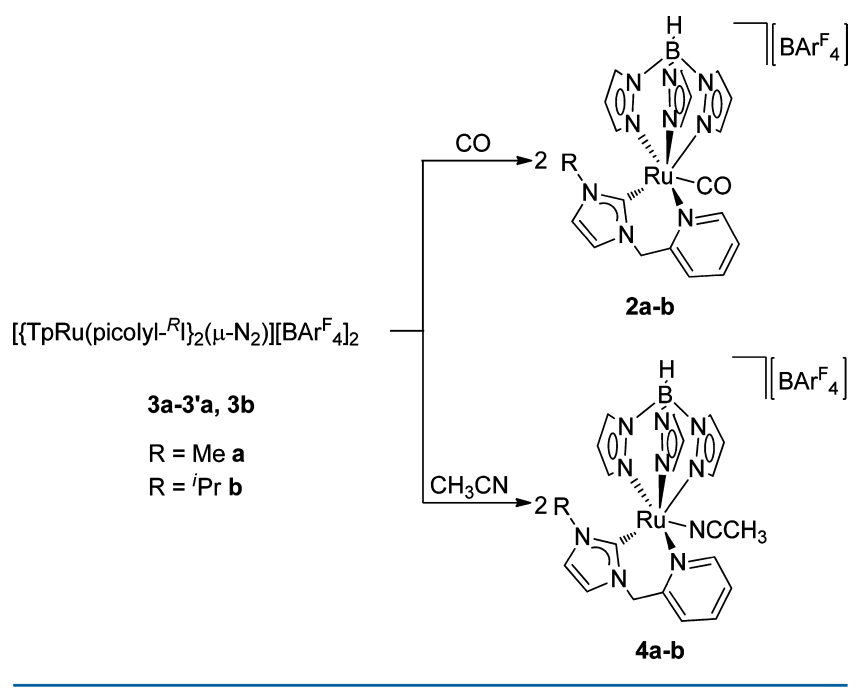

showed the typical characteristics of a coordinated $\mathrm{CH}_{3} \mathrm{CN}$ ligand with a singlet proton resonance of integral three at 2.20 and $2.21 \mathrm{ppm}$, for $\mathbf{4 a}$ and $\mathbf{4 b}$, respectively, as well as a coincidental carbon resonance at $3.93 \mathrm{ppm}$. The acetonitrile derivatives were also characterized by elemental analysis. Furthermore, $\mathbf{4 a}-\mathbf{b}$ were synthesized by treatment of a fluorobenzene solution of $\mathbf{1 a}-\mathbf{b}$ with $\mathrm{NaBAr}^{\mathrm{F}}{ }_{4}$ in the presence of acetonitrile.

Reactivity of $1 \mathrm{a}-\mathrm{e}$ with $\mathrm{H}_{2}$. Several attempts of binding $\mathrm{H}_{2}$ into the vacant coordination site at room temperature and lower temperatures failed to yield the desired products. The expected dihydrogen complexes were not synthesized in any case, but many decomposition products were observed in the reaction mixtures, presumably due to the instability of the in situ generated unsaturated $\mathrm{TpRu}$ 16-electron species. Additionally, the reaction under dihydrogen atmosphere was carried out in the presence of a base (ie. $\mathrm{NaOH}$ or $\mathrm{KO}^{t} \mathrm{Bu}$ ) to afford 
the corresponding $\mathrm{Ru}$-hydride derivatives, but in no case were the expected products obtained.

Reactivity of $1 \mathrm{a}-\mathrm{e}$ with $\mathrm{CH}_{2}=\mathrm{CH}_{2}$. The coordination of olefins to transition metal complexes has attracted much attention, given the fact that the activation of olefins is a key step in several catalytic processes. Recently, Gunnoe and coworkers have reported the participation of an ethylene intermediate when $\mathrm{TpRu}(\mathrm{L})(\mathrm{NCMe}) \mathrm{Ph}(\mathrm{L}=2,6,7$-trioxa-1phosphabicyclo[2,2,1]heptanes, $\mathrm{PMe}_{3}, \mathrm{P}(\mathrm{pyr})_{3}, \mathrm{P}$ $\left.\left(\mathrm{OCH}_{2}\right)_{3} \mathrm{CEt}\right)$ complexes are used as catalysts in olefin hydroarylation reactions. ${ }^{40}$ Also, Delaude and co-workers described the synthesis and catalytic applications of homobimetallic ruthenium-arene complexes bearing phosphine or NHC ligands starting from a ruthenium-ethylene complex. ${ }^{41}$ Furthermore, Severin and co-workers reported the use of dinuclear ruthenium-ethylene complexes and its application in atom transfer radical addition (ATRA) and atom transfer radical polymerization (ATRP) reactions. ${ }^{42}$ Thus, we decided to study the reactivity of the new ruthenium(II) picolyl-NHC complexes 1a-e toward ethylene.

A fluorobenzene solution of $\mathbf{1 a}$ and $\mathrm{NaBAr}^{\mathrm{F}}{ }_{4}$ under ethylene atmosphere was stirred at room temperature for an hour. The resulting orange solid proved to be the ethylene derivative $\mathbf{5 a}$, $\left[\mathrm{TpRu}\left(\kappa^{2}-C, N\right.\right.$-picolyl- $\left.{ }^{M e} \mathrm{I}\right)\left(\eta^{2}-\mathrm{CH}_{2} \mathrm{CH}_{2}\right]\left[\mathrm{BAr}^{\mathrm{F}}{ }_{4}\right]$, obtained in $88 \%$ yield and characterized using ${ }^{1} \mathrm{H}$ NMR, ${ }^{13} \mathrm{C}\left\{{ }^{1} \mathrm{H}\right\} \mathrm{NMR}$, and elemental analysis. This compound is stable in solution under $\mathrm{Ar}$ atmosphere, and the coordination of ethylene proved to be irreversible, considering that no differences in the NMR spectra were observed after freeze-pump-thaw degassing the sample. The protons of the $\mathrm{C}_{2} \mathrm{H}_{4}$ ligand appeared in the ${ }^{1} \mathrm{H}$ NMR spectrum as two multiplets at 4.07 and $3.68 \mathrm{ppm}$, respectively. The ethylene carbon atoms appeared as one singlet at $71.3 \mathrm{ppm}$ in the ${ }^{13} \mathrm{C}\left\{{ }^{1} \mathrm{H}\right\}$ NMR spectrum. This signal was observed for the half-sandwich cationic complexes $\left[\left(\eta^{5}\right.\right.$ $\left.\left.\mathrm{C}_{5} \mathrm{H}_{5}\right) \mathrm{Ru}\left(\mathrm{Ph}_{2} \mathrm{PCH}_{2} \mathrm{CH}_{2} \mathrm{Im}\right)\left(\eta^{2}-\mathrm{CH}_{2} \mathrm{CH}_{2}\right)\right]^{+},{ }^{43}\left[\left(\eta^{5}-\mathrm{C}_{5} \mathrm{Me}_{5}\right)-\right.$ $\left.\mathrm{Ru}\left(\eta^{2}-\mathrm{C}_{2} \mathrm{H}_{4}\right)(\mathrm{CO})\left(\mathrm{PMe}^{i} \mathrm{Pr}_{2}\right)\right]^{+},{ }^{44 a}\left[\left(\eta^{5}-\mathrm{C}_{5} \mathrm{Me}_{5}\right) \mathrm{Ru}\left(\eta^{2}-\mathrm{C}_{2} \mathrm{H}_{4}\right)-\right.$ (dippe) $]^{+}, 44 \mathrm{~b}\left[\left(\eta^{5}-\mathrm{C}_{5} \mathrm{H}_{5}\right) \mathrm{Ru}\left(\eta^{2}-\mathrm{C}_{2} \mathrm{H}_{4}\right)\right.$ (dippe $\left.)\right]^{+}, 44 \mathrm{~b}$ and $\left[\left(\eta^{5}-\right.\right.$ $\left.\left.\mathrm{C}_{5} \mathrm{Me}_{5}\right) \mathrm{Ru}\left(\eta^{2}-\mathrm{C}_{2} \mathrm{H}_{4}\right)(\mathrm{P} \sim \mathrm{O})_{2}\right]^{+}, 44 \mathrm{c}$ at higher field, 37.3, 47.3, $39.9,33.3$, and $46.9 \mathrm{ppm}$, respectively, indicating the presence of a $\mathrm{C}=\mathrm{C}$ bond with stronger double bond character in the $\mathrm{TpRu}$ complex, 5a. Continuing the reactivity study, a fluorobenzene solution of the isopropyl analogue, $\mathbf{1 b}$, and $\mathrm{NaBAr}_{4}^{\mathrm{F}}$ under ethylene atmosphere was allowed to react at room temperature for an hour. The $\eta^{2}$-ethylene derivative, $\mathbf{5 b}$, was obtained in almost quantitative yield, 97\%, as yellow crystals. Complex $\mathbf{5 b}$ was characterized using NMR spectroscopy, and as in the case of $\mathbf{5 a}$, the main spectroscopic characteristic is the low field ${ }^{13} \mathrm{C}\left\{{ }^{1} \mathrm{H}\right\}$ NMR shift of the ethylene carbon at $70.8 \mathrm{ppm}$. Furthermore, X-ray quality crystals were obtained by slow diffusion of petroleum ether into a concentrated diethyl ether solution. The ORTEP diagram of $\mathbf{5 b}$ is displayed in Figure 10.

In this complex, $\mathrm{Ru}$ (II) has a distorted octahedral geometry where the dihapto ethylene ligand formally occupies one coordination site. The angle $\mathrm{N}(5)-\mathrm{Ru}(1)-($ ethylene centroid) is $178.87(11)^{\circ}$ and other ligands form angles with the ethylene centroid in the range $93.35(19)-94.6(2)^{\circ}$. Also, the greatest deviation from linearity is found in the axis $\mathrm{N}(1)-\mathrm{Ru}(1)-\mathrm{N}(9)$ $170.89(12)^{\circ}$, and bond angles between ligands in cis range from $84.07(12)^{\circ}$ to $98.29(13)^{\circ}$. Imidazolyl and pyridyl rings in the chelating NHC ligand form a dihedral angle of $54.47(16)^{\circ}$. In comparison with other cases discussed in this Article, the steric hindrance of ethylene ligand causes a worse alignment of

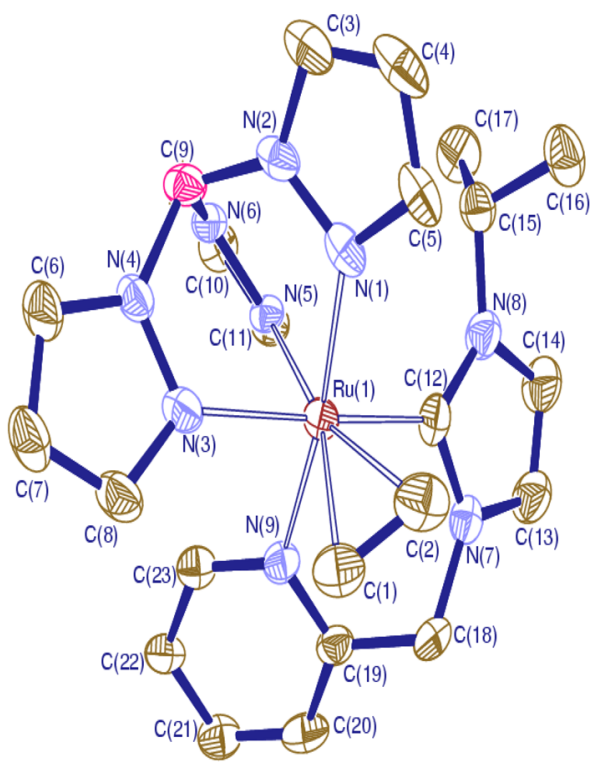

Figure 10. ORTEP diagram of the cation $\left[\mathrm{TpRu}\left(\kappa^{2}-C, N\right.\right.$-picolyl $\left.-{ }^{i P r} \mathrm{I}\right)-$ $\left.\left(\eta^{2}-\mathrm{CH}_{2}=\mathrm{CH}_{2}\right)\right]^{+}$(picolyl- ${ }^{i{ }^{P} r} \mathrm{I}=3$-isopropyl-1-(2-picolyl)imidazol-2ylidene) in $\mathbf{5 b}$ with $\mathbf{5 0} \%$ probability ellipsoids. Hydrogen atoms have been omitted for clarity. Color code: Ru, dark red; N, blue; C, brown; B, pink.

these rings with the pyrazolyl rings trans to them, showing dihedral angles of $22.98(22)^{\circ}$ for the imidazolyl ring and $16.38(14)^{\circ}$ for the pyridyl ring. The distance $\mathrm{Ru}(1)-($ ethylene centroid) is 2.126(5) $\AA$. $\mathrm{Ru}-\mathrm{N}$ bond lengths increase from 2.068(3) $\AA$ for $\mathrm{N}(5)$ trans to $\eta^{2}-\mathrm{CH}_{2}=\mathrm{CH}_{2}$ to 2.154(3) $\AA$ for $\mathrm{N}(3)$ trans to the imidazol-2-ylidene carbon $\mathrm{C}(12)$. As in the other structures reported in this work, the carbenic NHC carbon exhibits the largest trans influence. Although some structures of $\mathrm{CpRu}$ and $\mathrm{Cp} * \mathrm{Ru}$ with dihapto-ethylene have been described, there are no structures of $\mathrm{TpRu}$ with this ligand. The distance $\mathrm{C}(1)-\mathrm{C}(2)$ 1.346(6) $\AA$ indicates less relaxation of the double bond in comparison with other mono $\pi$-olefins linked to the TpRu fragment. ${ }^{45}$

Following the synthesis of complexes $\mathbf{5 a}-\mathbf{b}$, several attempts of obtaining the ethylene derivatives of $1 \mathbf{c}-\mathbf{e}$ were completed. However, in no case was it possible to obtain an isolable product. NMR spectra of the reaction mixtures showed the presence of several compounds as well as some paramagnetic impurities.

Reactivity of $1 \mathrm{a}-\mathrm{e}$ with $\mathrm{S}_{8}$. The interest in transitionmetal complexes with sulfur containing ligands has increased due to their application as model compounds for biological systems. Our group has reported the reactivity of cyclopentadienyl ruthenium(II) complexes bearing phosphine ligands with $\mathrm{H}_{2} \mathrm{~S}$ and elemental sulfur. ${ }^{46}$ Continuing the reactivity study toward small molecules, the next step was to use elemental sulfur. An excess of elemental sulfur was added to the fluorobenzene solutions of $1 \mathbf{a}-\mathbf{e}$ and $\mathrm{NaBAr}_{4}^{\mathrm{F}}$. The resulting solids were isolated after stirring the solutions for 1 $\mathrm{h}$, filtering through a pad of Celite, and removing the solvent. The reaction mixtures were analyzed by NMR spectroscopy. However, only in the case of $\mathbf{1 a}$ was a single product isolated, resulting in the formation of the disulfide complex $\left[\left\{\mathrm{TpRu}\left(\kappa^{2}-\right.\right.\right.$ $C, N$-picolyl- $\left.\left.\left.{ }^{M e} \mathrm{I}\right)\right\}_{2}\left(\mu-\mathrm{S}_{2}\right)\right]\left[\mathrm{BAr}_{4}^{\mathrm{F}}\right]_{2}$, 6. A few other disulfide ruthenium complexes have been reported, particularly using the method described by Rauchfuss and co-workers. ${ }^{46,47}$ The ${ }^{1} \mathrm{H}$ NMR spectra of $\mathbf{6}$ is characteristic for centrosymmetrical 
$\left\{\mathrm{TpRu}\left(\kappa^{2}-C, N \text {-picolyl- }{ }^{\mathrm{Me}} \mathrm{I}\right)\right\}_{2}$ moieties showing a single set of proton resonances. In the ${ }^{1} \mathrm{H}$ NMR spectrum, nine signals corresponding to the $\mathrm{Tp}$ ligand are observed, in addition to a set of doublets corresponding to the methylene bridge at 5.21 and 5.19 ppm, respectively. Also, the ${ }^{13} \mathrm{C}\left\{{ }^{1} \mathrm{H}\right\}$ NMR spectra showed the $\mathrm{Ru}-\mathrm{C}_{2}-\mathrm{NHC}$ chemical shift at $174.3 \mathrm{ppm}$. It is interesting that in the case of disulfide complex no isomerization is observed, in comparison with the dinitrogen-bridged analogues. Furthermore, crystals of 6 suitable for X-ray diffraction studies were obtained from slow diffusion of petroleum ether into a concentrated diethyl ether solution. The ORTEP diagram of 6 is displayed in Figure 11. This is the

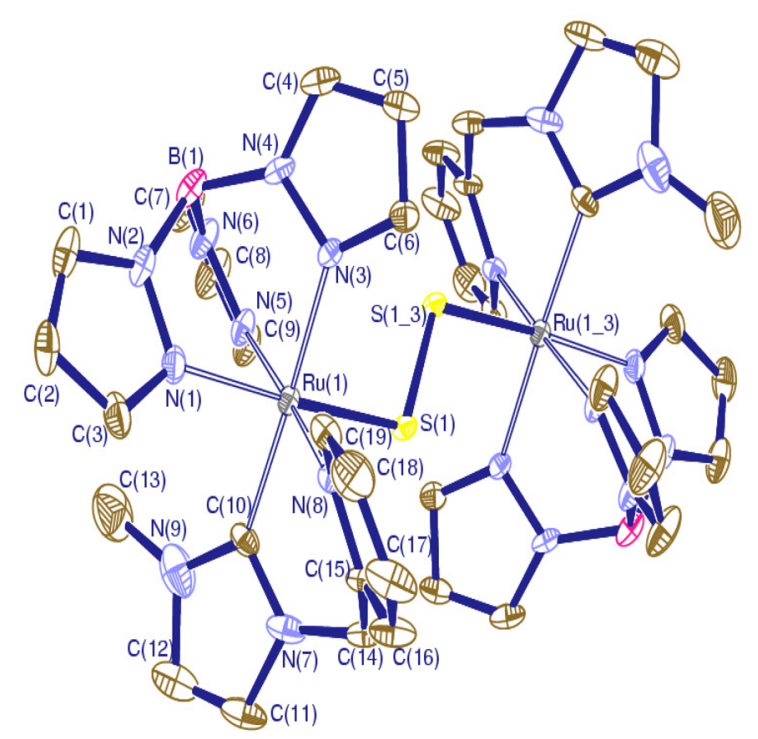

Figure 11. ORTEP diagram for $\left[\left\{\mathrm{TpRu}\left(\kappa^{2}-C, N \text {-picolyl }{ }^{M e} \mathrm{I}\right)\right\}_{2}(\mu\right.$ $\left.\left.\mathrm{S}_{2}\right)\right]^{2+}$ (picolyl- ${ }^{\mathrm{Me}} \mathrm{I}=3$-methyl-1-(2-picolyl)imidazol-2-ylidene) in 6 with $50 \%$ probability ellipsoids. Hydrogen atoms have been omitted for clarity. Color code: $\mathrm{Ru}$, dark red; N, blue; C, brown; B, pink; S, yellow.

second disulfide ruthenium complex characterized crystallographically; previously, Amarasekara et. al reported the X-ray crystallographic analysis of $\left[\left\{\left(\eta^{5}-\mathrm{C}_{5} \mathrm{H}_{5}\right) \mathrm{Ru}\left(\mathrm{PMe}_{3}\right)_{2}\right\}_{2}\left(\mu-\mathrm{S}_{2}\right)\right]$ $\left[\mathrm{SbF}_{6}\right]_{2}{ }^{47}$ and the first one bearing $\mathrm{Tp}$ and NHC ligands.

The structure of the divalent cation $\left[\left\{\mathrm{TpRu}\left(\kappa^{2}-C, N-\right.\right.\right.$ picolyl $\left.\left.\left.{ }^{M e} \mathrm{I}\right)\right\}_{2}\left(\mu-S_{2}\right)\right]^{2+}$ shows a half repeated unit through the inversion center in the middle of the two $S$ atoms. In contrast to other cases described in this work, the ruthenium atom shows a less distorted octahedral geometry, with axis ranging from $\mathrm{N}(5)-\mathrm{Ru}(1)-\mathrm{N}(8) 176.08(13)^{\circ}$ to $\mathrm{S}(1)-\mathrm{Ru}(1)-\mathrm{N}(1)$ $176.83(10)^{\circ}$. In general, bond angles between ligands in cis are closer to the ideal value of $90^{\circ}$, in the interval 85.71(13)$95.06(16)^{\circ}$. In addition, imidazolyl and pyridyl rings in the chelating NHC ligands form a dihedral angle of $57.27(17)^{\circ}$. The alternating arrangement of the opposite ligand rings around ruthenium is even more regular than in the previous cases described in this work. The dihedral angle between the imidazolyl ring and the pyrazolyl ring in trans to it is $8.59(38)^{\circ}$, whereas the analogous angle for the pyridyl ring is $7.87(25)^{\circ}$, both lower than $10^{\circ}$. Also, the largest trans influence is exhibited by the carbenic $\mathrm{C}$ as evidenced by the largest $\mathrm{Ru}-\mathrm{N}$ bond distance for $\mathrm{Ru}(1)-\mathrm{N}(3), 2.110(3) \AA$. The disulfide bridge ligand binds $\mathrm{Ru}$ with a bond length of 2.218(1) $\AA$, whereas the sulfur-sulfur distance is $1.987(2) \AA$, and the angle

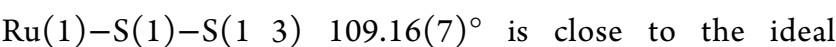
tetrahedral value. All these values are similar to those reported for the related complex $\left[\left\{\mathrm{CpRu}\left(\mathrm{PMe}_{3}\right)_{2}\right\}_{2}\left(\mu_{2}-\mathrm{S}_{2}\right)\right]\left[\mathrm{SbF}_{6}\right]_{2}{ }^{47}$ indicating an appreciable double-bond character for the $\mu-S_{2}$ unit.

Reactivity of $1 \mathbf{a}-\mathbf{b}$ with $\mathrm{O}_{2}$. The activation of dioxygen by transition metal complexes has attracted significant interest considering the possible applications in many catalytic organic oxidation reactions. ${ }^{48}$ Our recent work showed that $\left[\left(\eta^{5}-\right.\right.$ $\left.\mathrm{C}_{5} \mathrm{Me}_{5}\right) \mathrm{Ru}\left(\kappa^{2}-\mathrm{C}, N\right.$-picolyl $\left.\left.{ }^{i P r} \mathrm{I}\right) \mathrm{CH}_{3} \mathrm{CN}\right]\left[\mathrm{BAr}^{\mathrm{F}}{ }_{4}\right]$ in the presence of air afforded the $\eta^{2}$-dioxygen complex, $\left[\left(\eta^{5}-\mathrm{C}_{5} \mathrm{Me}_{5}\right) \mathrm{Ru}\left(\kappa^{2}\right.\right.$ $C, N$-picolyl- $\left.\left.{ }^{i P r} \mathrm{I}\right)\left(\eta^{2}-\mathrm{O}_{2}\right)\right]\left[\mathrm{BAr}^{\mathrm{F}}{ }_{4}\right] .{ }^{24}$ In light of this and the work previously reported by Whittlesey and co-workers, regarding the formation of $\left[\mathrm{Ru}(\mathrm{NHC})_{4}\left(\eta^{2}-\mathrm{O}_{2}\right) \mathrm{H}\right]\left[\mathrm{BAr}_{4}^{\mathrm{F}}\right]$ and its reversible coordination, ${ }^{49}$ the reaction of $1 \mathrm{a}-\mathrm{e}$ with $\mathrm{NaBAr}^{\mathrm{F}}$ as halide scavenger in the presence of air and dioxygen was investigated. The reactions were carried out in fluorobenzene at room temperature, and in all cases, an immediate color change from yellow-red to green/green-brown was observed. The ${ }^{1} \mathrm{H}$ NMR spectra of the reaction mixtures showed broad signals indicating the presence of paramagnetic species, generated after oxidation reactions. Crystallization of the reaction mixtures was attempted several times, but no material suitable for X-ray diffraction study was obtained.

\section{CONCLUDING REMARKS}

In continuation with our research with picolyl-NHC complexes of ruthenium, we have developed a high yield synthetic route to new hydrotris(pyrazolyl)borate ruthenium(II) NHC complexes, 1a-e. The complexes have been prepared using the transmetalation method from the in situ generated silver carbenes, with the appropriate imidazolium salts and silver oxide, and its reaction with $[\mathrm{TpRu}(\mathrm{COD}) \mathrm{Cl}]$. In contrast to the ruthenium(II)-arene analogues previously generated by our group, ${ }^{29}$ these transformation required high energy to complete the COD ligand substitution. Also, the crystal structure of $\mathbf{1} \mathbf{b}$ has been determined. We have studied the influence of picolyl-NHC ligands in the ruthenium center, after systematically varying the imidazolydene ring $\mathrm{N}$-wingtip and backbone substituents, via the synthesis and characterization of the carbonyl derivatives $\mathbf{2 a}-\mathbf{e}$.

The reaction of the coordinatively unsaturated $\left[\mathrm{TpRu}\left(\kappa^{2}-\right.\right.$ $\mathrm{C}, \mathrm{N}$-picolyl-NHC) $]^{+}$species, generated in situ using $\mathrm{NaBAr}_{4}{ }_{4}$ as a halide scavenger, with small molecules indicated that the reactivity is strongly affected by the NHC wingtip and backbone substituents. $\left[\mathrm{TpRu}\left(\kappa^{2}-C, N \text {-picolyl- }{ }^{M e} \mathrm{I}\right)\right]^{+}$reacted with nitrogen to give an equimolar mixture of dinitrogenbridged complexes, $\mathbf{3} \mathbf{a}$ and $\mathbf{3}^{\prime} \mathbf{a}$, while in the presence of ethylene atmosphere or elemental sulfur, led to the isolation of the $\mathrm{TpRu} \eta^{2}$-ethylene derivative, $\mathbf{5 a}$, and the bridged $\mathrm{TpRu}$ disulfide complex, 6, respectively. All complexes were spectroscopically characterized, and in the case of $\mathbf{3}^{\prime} \mathbf{a}$ and $\mathbf{6}$, structurally characterized using X-ray diffraction. In contrast, $\left[\mathrm{TpRu}\left(\kappa^{2}-C, N \text {-picolyl }{ }^{i{ }^{P r}} \mathrm{I}\right)\right]^{+}$reacted with nitrogen to give a single dinitrogen bridged complex, $3 \mathbf{b}$, and under ethylene atmosphere led to the isolation of the $\eta^{2}$-ethylene derivative, 5b. However, $\left[\mathrm{TpRu}\left(\kappa^{2}-C, N-\text { picolyl }{ }^{i{ }^{P r}} \mathrm{I}\right)\right]^{+}$failed to give any isolable product upon reaction with elemental sulfur. It is important to note that $\mathbf{5 b}$ is the first example of a structurally characterized (via X-ray diffraction study) ethylene dihapto $\mathrm{TpRu}$ complex. The $\left[\mathrm{TpRu}\left(\kappa^{2}-C, N \text {-picolyl }{ }^{M e} 45 \mathrm{DClI}\right)\right]^{+}$species decomposes upon exposure to all small molecules tested, except with $\mathrm{CO}$, indicating the high instability of the 
unsaturated complex. Also, $\left[\mathrm{TpRu}\left(\kappa^{2}-C, N-\text { picolyl }^{P h} \mathrm{I}\right)\right]^{+}$reactivity toward nitrogen generated, after recrystallization, a single dinitrogen bridged complex, $3^{\prime} \mathrm{d}$, that in solution isomerizes to a mixture of diastereoisomers, $\mathbf{3 d}$ and $\mathbf{3}^{\prime} \mathbf{d}$, and the mononuclear nitrogen complex, 3 "d. Nevertheless, the phenyl derivative unsaturated complex decomposes upon exposure to ethylene and sulfur. The crystal structure of $3^{\prime} \mathbf{d}$ has been obtained. Furthermore, $\left[\mathrm{TpRu}\left(\kappa^{2}-C, N \text {-picolyl- }{ }^{\mathrm{Me}} \mathrm{BI}\right)\right]^{+}$in the presence of nitrogen led to a mixture of diastereoisomers, $3 \mathrm{e}$ and $3^{\prime} \mathbf{e}$, and the mononuclear nitrogen complex, $3^{\prime \prime} \mathrm{e}$ in the solid state and in solution. Besides, the reactivity of $1 \mathrm{e}$ proved to be similar to the case of the dichloro and phenyl derivative, failing to give an isolable product after reaction with ethylene and sulfur. The reactivity toward oxygen is independent of the picolyl-NHC ligands, $\mathbf{1 a}-\mathbf{e}$, led to uncharacterizable oxidation products. The application of the new hydrotris(pyrazolyl)borate ruthenium(II) picolyl- ${ }^{R}$ I derivatives generated with these labile ligands in different catalytic processes is ongoing.

Finally, it is important to note that, in all crystal structures reported in this work, the largest trans influence is exhibited by the carbenic carbon of the NHCs. This feature should be considered when studying their reactivity and catalytic applications.

\section{EXPERIMENTAL SECTION}

General Methods. Unless otherwise stated, all manipulations were carried out under dry nitrogen or argon using conventional Schlenk techniques. Tetrahydrofuran, diethyl ether, and petroleum ether (boiling range $40-60{ }^{\circ} \mathrm{C}$ ) were obtained oxygen and water-free with an Innovative Technology Inc. solvent purification system. Acetonitrile, dichloromethane, dicholoroethane, and dimethylformamide were of anhydrous quality and used as received. All solvents were degassed immediately prior to use. 3-(Methyl)-1-(2-picolyl)imidazolium bromide (a), ${ }^{50} 3$-(isopropyl)-1-(2-picolyl)imidazolium bromide (b), ${ }^{51} 3$ (methyl)-1-(2-picolyl)benzoimidazolium bromide (e) ${ }^{52}$ 3-phenyl-1(2-picolyl)imidazolium bromide, ${ }^{24}$ 3-methyl-1-(2-picolyl)-4,5-dichloroimidazolium bromide, ${ }^{24}[\mathrm{TpRu}(\mathrm{COD}) \mathrm{Cl}]{ }^{18 \mathrm{f}}$ and $\mathrm{NaBAr}_{4}^{\mathrm{F}}{ }_{4}^{53}$ were prepared using slightly modified versions of the published procedures. All other reagents were purchased from commercial sources and used without further purification.

NMR spectra were recorded using Varian INOVA $400 \mathrm{MHz}$, Agilent 500, and Varian Inova $600 \mathrm{MHz}$ spectrometers, and chemical shifts are reported relative to tetramethylsilane, $\mathrm{Si}\left(\mathrm{CH}_{3}\right)_{4}$, for ${ }^{1} \mathrm{H}$ and ${ }^{13} \mathrm{C}\left\{{ }^{1} \mathrm{H}\right\}$ signals. Assignments of ${ }^{1} \mathrm{H}$ and ${ }^{13} \mathrm{C}\left\{{ }^{1} \mathrm{H}\right\}$ NMR spectra were made on the basis of $2 \mathrm{D}$ NMR experiments. IR spectra were recorded in Nujol mulls with a Perkin-Elmer FTIR Spectrum 1000 spectrophotometer. Raman spectra were recorded with a BTWTec iRaman spectrophotometer. Microanalyses were performed with a LECO CHNS-932 elemental analyzer by Servicios Centrales de Ciencia y Tecnología, Universidad de Cádiz. Synthesis and characterization data of selected compounds is presented in the experimental section.

Representative Procedure for Synthesis of $\operatorname{TpRu}\left(\kappa^{2}-\mathrm{C}, N-\right.$ picolyl-NHC)Cl Complexes 1a-e. A suspension of the appropriate picolyl imidazolium bromide (a-e) and silver oxide (1 equiv) in 1,2dichloroethane was stirred at room temperature in the dark for $3 \mathrm{~h}$. The resulting light yellow mixture was then filtered through a pad of Celite into a suspension of $[\mathrm{TpRu}(\mathrm{COD}) \mathrm{Cl}]$ in $\mathrm{DMF}$ and stirred at $150{ }^{\circ} \mathrm{C}$ for $5 \mathrm{~h}$. The suspension color changed from light yellow to orange and was filtered through Celite to remove silver salts, and the solvent was removed under reduced pressure. The resulting solid was extracted with THF and filtered through a pad of Celite to remove the insoluble residues, and the solvent was removed under reduced pressure. The resulting solid was washed with ether, dried under vacuum, and recrystallized from $\mathrm{CH}_{2} \mathrm{Cl}_{2}$ /hexane.

[TpRuCl( $\left.\left.\kappa^{2}-C, N-3-m e t h y l-1-(2-p i c o l y l) i m i d a z o l-2-y l i d e n e\right)\right]$ (1a). Transmetalation was carried out in 1,2-dichloroethane $(15 \mathrm{~mL})$ with 1-methyl-3-picolylimidazolium bromide a (381.2 mg, $1.5 \mathrm{mmol}), \mathrm{Ag}_{2} \mathrm{O}$ $(173.8 \mathrm{mg}, 0.75 \mathrm{mmol})$, and [TpRu(COD)Cl] $(457.7 \mathrm{mg}, 1.0 \mathrm{mmol})$ in DMF $(15 \mathrm{~mL})$. The product was an orange microcrystalline solid. Yield: $317.3 \mathrm{mg}, 81 \% .{ }^{1} \mathrm{H}$ NMR $\left(\mathrm{CD}_{2} \mathrm{Cl}_{2}, 600 \mathrm{MHz}\right): \delta 7.82\left(\mathrm{~d},{ }^{3} J_{\mathrm{HH}}=\right.$ $\left.2.30 \mathrm{~Hz}, 1 \mathrm{H}, \mathrm{H}_{\mathrm{Tp}}\right), 7.76\left(\mathrm{~d},{ }^{3} J_{\mathrm{HH}}=2.49 \mathrm{~Hz}, 1 \mathrm{H}, \mathrm{H}_{\mathrm{Tp}}\right), 7.64\left(\mathrm{~d},{ }^{3} \mathrm{~J}_{\mathrm{HH}}=\right.$ $\left.2.11 \mathrm{~Hz}, 1 \mathrm{H}, \mathrm{H}_{\mathrm{Tp}}\right), 7.62\left(\right.$ br s, $\left.1 \mathrm{H}, \mathrm{H}_{\mathrm{Tp}}\right), 7.52\left(\mathrm{br} \mathrm{s}, 1 \mathrm{H}, \mathrm{H}_{\mathrm{Tp}}\right), 7.49(\mathrm{t}$, ${ }^{3} \mathrm{~J}_{\mathrm{HH}}=7.68 \mathrm{~Hz}, 1 \mathrm{H}, \mathrm{H}_{\text {pyridine }}$ ), 7.47 (d, ${ }^{3} \mathrm{~J}_{\mathrm{HH}}=5.57 \mathrm{~Hz}, 1 \mathrm{H}, \mathrm{H}_{\text {pyridine }}$ ), $7.36\left(\mathrm{~d},{ }^{3} J_{\mathrm{HH}}=7.67 \mathrm{~Hz}, 1 \mathrm{H}, \mathrm{H}_{\text {pyridine }}\right), 7.22\left(\mathrm{~d},{ }^{2} J_{\mathrm{HH}}=15.06 \mathrm{~Hz}, 1 \mathrm{H}\right.$, $\left.\mathrm{H}_{\text {bridge }}\right), 7.20\left(\mathrm{~d},{ }^{3} J_{\mathrm{HH}}=1.92 \mathrm{~Hz}, 1 \mathrm{H}, \mathrm{H}_{\text {imid }}\right), 6.76\left(\mathrm{~d},{ }^{3} \mathrm{~J}_{\mathrm{HH}}=1.73 \mathrm{~Hz}\right.$, $\left.1 \mathrm{H}, \mathrm{H}_{\text {imid }}\right), 6.75\left(\mathrm{t},{ }^{3} J_{\mathrm{HH}}=7.43 \mathrm{~Hz}, 1 \mathrm{H}, \mathrm{H}_{\text {pyridine }}\right), 6.29\left(\mathrm{vt},{ }^{3} \mathrm{~J}_{\mathrm{HH}}=2.02\right.$ $\left.\mathrm{Hz}, 1 \mathrm{H}, \mathrm{H}_{\mathrm{Tp}}\right), 6.13\left(\mathrm{vt},{ }^{3} J_{\mathrm{HH}}=2.03 \mathrm{~Hz}, 1 \mathrm{H}, \mathrm{H}_{\mathrm{Tp}}\right), 5.91\left(\mathrm{vt},{ }^{3} \mathrm{~J}_{\mathrm{HH}}=2.02\right.$ $\left.\mathrm{Hz}, 1 \mathrm{H}, \mathrm{H}_{\mathrm{Tp}}\right), 5.75\left(\right.$ br s, $\left.1 \mathrm{H}, \mathrm{H}_{\mathrm{Tp}}\right), 5.00\left(\mathrm{~d},{ }^{2} J_{\mathrm{HH}}=14.39 \mathrm{~Hz}, 1 \mathrm{H}\right.$, $\left.\mathrm{H}_{\text {bridge }}\right), 2.42\left(\mathrm{~s}, 3 \mathrm{H}, \mathrm{NCH}_{3}\right) .{ }^{13} \mathrm{C}\left\{{ }^{1} \mathrm{H}\right\} \operatorname{NMR}\left(\mathrm{CD}_{2} \mathrm{Cl}_{2}, 150 \mathrm{MHz}\right): \delta$ $192.3\left(\mathrm{C}_{\text {imid }} \mathrm{Ru}\right), 161.3\left(\mathrm{C}_{\mathrm{py}}\right), 157.8\left(\mathrm{C}_{\mathrm{py}}\right), 145.4(\mathrm{Tp}), 143.4(\mathrm{Tp})$, $142.7(\mathrm{Tp}), 136.4(\mathrm{Tp}), 135.1(\mathrm{Tp}), 134.8(\mathrm{Tp}), 134.2\left(\mathrm{C}_{\mathrm{py}}\right), 123.2$ $\left(\mathrm{C}_{\mathrm{py}}\right), 122.6\left(\mathrm{C}_{\mathrm{py}}\right), 121.9\left(\mathrm{C}_{\text {imid }}\right), 121.5\left(\mathrm{C}_{\text {imid }}\right), 105.9(\mathrm{Tp}), 105.8$ (Tp), $105.6(\mathrm{Tp}), 55.8\left(\mathrm{CH}_{2}\right), 35.0\left(\mathrm{NCH}_{3}\right)$. Anal. Calcd. for $\mathrm{C}_{19} \mathrm{H}_{21} \mathrm{BClN}_{9} \mathrm{Ru}: \mathrm{C} 43.65, \mathrm{H} 4.05, \mathrm{~N} 24.11$. Found: C 43.58, H 4.10, $\mathrm{N} 24.15$.

[TpRuCl( $\kappa^{2}-\mathrm{C}, \mathrm{N}$-3-isopropyl-1-(2-picolyl)imidazol-2-ylidene)].0.8C $\mathrm{C}_{2} \mathrm{Cl}_{2}(\mathbf{1} \boldsymbol{b})$. Transmetalation was carried out in 1,2-dichloroethane $(15 \mathrm{~mL})$ with 1-isopropyl-3-picolylimidazolium bromide $\mathbf{b}$ (424.8 mg, $1.5 \mathrm{mmol}), \mathrm{Ag}_{2} \mathrm{O}(173.8 \mathrm{mg}, 0.75 \mathrm{mmol})$, and [TpRu(COD)Cl] $(457.7 \mathrm{mg}, 1.0 \mathrm{mmol})$ in DMF $(15 \mathrm{~mL})$. The product was a red microcrystalline solid. Yield: $326.4 \mathrm{mg}, 79 \% .{ }^{1} \mathrm{H}$ $\operatorname{NMR}\left(\mathrm{CD}_{2} \mathrm{Cl}_{2}, 600 \mathrm{MHz}\right): \delta 7.82\left(\mathrm{~d},{ }^{3} J_{\mathrm{HH}}=2.30 \mathrm{~Hz}, 1 \mathrm{H}, \mathrm{H}_{\mathrm{Tp}}\right), 7.76$ $\left(\mathrm{d},{ }^{3} J_{\mathrm{HH}}=2.30 \mathrm{~Hz}, 2 \mathrm{H}, \mathrm{H}_{\mathrm{Tp}}\right), 7.66\left(\mathrm{~d},{ }^{3} J_{\mathrm{HH}}=1.53 \mathrm{~Hz}, 1 \mathrm{H}, \mathrm{H}_{\mathrm{Tp}}\right), 7.64$ $\left(\mathrm{t},{ }^{3} \mathrm{~J}_{\mathrm{HH}}=7.57 \mathrm{~Hz}, 1 \mathrm{H}, \mathrm{H}_{\text {pyridine }}\right), 7.60\left(\mathrm{~d},{ }^{3} J_{\mathrm{HH}}=1.72 \mathrm{~Hz}, 1 \mathrm{H}, \mathrm{H}_{\mathrm{Tp}}\right)$, $7.51\left(\mathrm{~d},{ }^{3} J_{\mathrm{HH}}=7.39 \mathrm{~Hz}, 1 \mathrm{H}, \mathrm{H}_{\text {pyridine }}\right), 7.50\left(\mathrm{~d},{ }^{3} \mathrm{~J}_{\mathrm{HH}}=1.92 \mathrm{~Hz}, 1 \mathrm{H}\right.$, $\left.\mathrm{H}_{\text {imid }}\right), 7.47\left(\mathrm{~d},{ }^{3} J_{\mathrm{HH}}=5.36 \mathrm{~Hz}, 1 \mathrm{H}, \mathrm{H}_{\text {pyridine }}\right), 7.22\left(\mathrm{~d},{ }^{3} \mathrm{~J}_{\mathrm{HH}}=1.92 \mathrm{~Hz}\right.$, $\left.1 \mathrm{H}, \mathrm{H}_{\text {imid }}\right), 7.18\left(\mathrm{~d},{ }^{2} J_{\mathrm{HH}}=14.20 \mathrm{~Hz}, 1 \mathrm{H}, \mathrm{H}_{\text {bridge }}\right), 6.88\left(\mathrm{t},{ }^{3} J_{\mathrm{HH}}=6.67\right.$ $\left.\mathrm{Hz}, 1 \mathrm{H}, \mathrm{H}_{\text {pyridine }}\right), 6.23\left(\mathrm{vt}^{3}{ }^{3} \mathrm{HH}_{\mathrm{HH}}=2.11 \mathrm{~Hz}, 1 \mathrm{H}, \mathrm{H}_{\mathrm{Tp}}\right), 6.12\left(\mathrm{vt},{ }^{3} J_{\mathrm{HH}}=\right.$ $\left.2.11 \mathrm{~Hz}, 1 \mathrm{H}, \mathrm{H}_{\mathrm{Tp}}\right), 5.99\left(\mathrm{vt},{ }^{3} J_{\mathrm{HH}}=2.11 \mathrm{~Hz}, 1 \mathrm{H}, \mathrm{H}_{\mathrm{Tp}}\right), 5.94\left(\mathrm{~d},{ }^{3} \mathrm{~J}_{\mathrm{HH}}=\right.$ $\left.1.54 \mathrm{~Hz}, 1 \mathrm{H}, \mathrm{H}_{\mathrm{Tp}}\right), 5.22\left(\mathrm{~d},{ }^{2} J_{\mathrm{HH}}=14.20 \mathrm{~Hz}, 1 \mathrm{H}, \mathrm{H}_{\mathrm{bridge}}\right), 3.08(\mathrm{~m}$, $\left.{ }^{3} J_{\mathrm{HH}}=6.71 \mathrm{~Hz}, 1 \mathrm{H}, \mathrm{CH}\right), 1.00\left(\mathrm{~d},{ }^{3} J_{\mathrm{HH}}=6.52 \mathrm{~Hz}, 3 \mathrm{H}, \mathrm{CH}_{3}\right), 0.66(\mathrm{~d}$, $\left.{ }^{3} \mathrm{~J}_{\mathrm{HH}}=6.72 \mathrm{~Hz}, 3 \mathrm{H}, \mathrm{CH}_{3}\right) \cdot{ }^{13} \mathrm{C}\left\{{ }^{1} \mathrm{H}\right\} \mathrm{NMR}\left(\mathrm{CD}_{2} \mathrm{Cl}_{2}, 150 \mathrm{MHz}\right): \delta$ $191.4\left(\mathrm{C}_{\text {imid }} \mathrm{Ru}\right), 162.7\left(\mathrm{C}_{\mathrm{py}}\right), 158.2\left(\mathrm{C}_{\mathrm{py}}\right), 146.6(\mathrm{Tp}), 144.6(\mathrm{Tp})$, $143.1(\mathrm{Tp}), 136.5(\mathrm{Tp}), 135.7(\mathrm{Tp}), 134.8(\mathrm{Tp}), 134.7\left(\mathrm{C}_{\mathrm{py}}\right), 123.7$ $\left(\mathrm{C}_{\mathrm{py}}\right), 123.1\left(\mathrm{C}_{\mathrm{py}}\right), 123.1\left(\mathrm{C}_{\text {imid }}\right), 117.0\left(\mathrm{C}_{\text {imid }}\right), 106.4(\mathrm{Tp}), 105.9$ $(\mathrm{Tp}), 105.5(\mathrm{Tp}), 55.6\left(\mathrm{CH}_{2}\right), 49.3(\mathrm{CH}), 24.8\left(\mathrm{CH}_{3}\right), 23.4\left(\mathrm{CH}_{3}\right)$. Anal. Calcd. for $\mathrm{C}_{21} \mathrm{H}_{25} \mathrm{BClN}_{9} \mathrm{Ru}+0.8 \mathrm{CH}_{2} \mathrm{Cl}_{2}: \mathrm{C} 42.32, \mathrm{H} 4.33, \mathrm{~N}$ 20.37. Found: C 42.27, H 4.28, N 20.41.

[TpRu $\kappa^{2}-\mathrm{C}, \mathrm{N}$-3-phenyl-1-(2-picolyl)imidazol-2-ylidene)(CO)]$\left[\mathrm{BAr}_{4}{ }_{4}\right] \cdot 0.5 \mathrm{Et} \mathrm{t}_{2} \mathrm{O}$ (2d). [TpRu$\left(\kappa^{2}-\mathrm{C}, \mathrm{N}\right.$-picolyl $\left.\left.{ }^{\mathrm{Ph}} \mathrm{I}\right) \mathrm{Cl}\right](117.0 \mathrm{mg}, 0.2$ $\mathrm{mmol})$ and $\mathrm{NaBAr}_{4}{ }_{4}(177.2 \mathrm{mg}, 0.2 \mathrm{mmol})$ were suspended in $6 \mathrm{~mL}$ of fluorobenzene under $1 \mathrm{~atm}$ of $\mathrm{CO}$, and an orange-yellow solution was observed. The mixture was stirred for $1 \mathrm{~h}$. The solvent was removed under reduced pressure. The solid was dissolved in $\mathrm{Et}_{2} \mathrm{O}$ (10 $\mathrm{mL}$ ) and filtered through a pad of Celite to remove $\mathrm{NaCl}$. The resulting red solution was layered with petroleum ether to yield red crystals. Yield: $262.2 \mathrm{mg}$ (91\%). ${ }^{1} \mathrm{H}$ NMR $\left(\mathrm{CD}_{3} \mathrm{NO}_{2}, 400 \mathrm{MHz}\right): \delta$ $8.08\left(\mathrm{~d},{ }^{3} \mathrm{~J}_{\mathrm{HH}}=2.0 \mathrm{~Hz}, 1 \mathrm{H}, \mathrm{H}_{\mathrm{Tp}}\right), 8.00\left(\mathrm{t},{ }^{3} \mathrm{~J}_{\mathrm{HH}}=7.6 \mathrm{~Hz}, 1 \mathrm{H}, \mathrm{H}_{\text {pyridine }}\right)$, $7.86\left(\right.$ br s, $\left.9 \mathrm{H}, \mathrm{BAr}^{\mathrm{F}}{ }_{4}+\mathrm{H}_{\mathrm{Tp}}\right), 7.83\left(\mathrm{~d},{ }^{3} J_{\mathrm{HH}}=7.68 \mathrm{~Hz}, 1 \mathrm{H}, \mathrm{H}_{\text {pyridine }}\right)$, $7.71\left(\mathrm{~d},{ }^{3} \mathrm{~J}_{\mathrm{HH}}=2.4 \mathrm{~Hz}, 1 \mathrm{H}, \mathrm{H}_{\mathrm{Tp}}\right), 7.68\left(\mathrm{br} \mathrm{s}, 4 \mathrm{H}, \mathrm{BAr}^{\mathrm{F}}{ }_{4}\right), 7.66\left(\mathrm{~d},{ }^{3} J_{\mathrm{HH}}\right.$ $\left.=2.6 \mathrm{~Hz}, 1 \mathrm{H}, \mathrm{H}_{\text {imid }}\right), 7.64\left(\mathrm{~d},{ }^{3} \mathrm{JHH}_{\mathrm{HH}}=5.8 \mathrm{~Hz}, 1 \mathrm{H}, \mathrm{H}_{\text {pyridine }}\right), 7.49(\mathrm{~d}$, $\left.{ }^{3} \mathrm{~J}_{\mathrm{HH}}=2.0 \mathrm{~Hz}, 1 \mathrm{H}, \mathrm{H}_{\mathrm{Tp}}\right), 7.24-7.21\left(\mathrm{~m}, 2 \mathrm{H}, \mathrm{H}_{\text {pyridine }}+\mathrm{H}_{\mathrm{imid}}\right), 7.11(\mathrm{~d}$, $\left.{ }^{3} J_{\mathrm{HH}}=2.0 \mathrm{~Hz}, 1 \mathrm{H}, \mathrm{H}_{\mathrm{Tp}}\right), 7.03\left(\mathrm{t},{ }^{3} \mathrm{~J}_{\mathrm{HH}}=7.3 \mathrm{~Hz}, 1 \mathrm{H}, \mathrm{H}_{\mathrm{Ph}}\right), 6.91\left(\mathrm{t},{ }^{3} \mathrm{~J}_{\mathrm{HH}}\right.$ $\left.=7.8 \mathrm{~Hz}, 2 \mathrm{H}, \mathrm{H}_{\mathrm{Ph}}\right), 6.79\left(\mathrm{~d},{ }^{3} J_{\mathrm{HH}}=1.5 \mathrm{~Hz}, 1 \mathrm{H}, \mathrm{H}_{\mathrm{Tp}}\right), 6.38\left(\mathrm{vt},{ }^{3} J_{\mathrm{HH}}=\right.$ $\left.2.2 \mathrm{~Hz}, 1 \mathrm{H}, \mathrm{H}_{\mathrm{Tp}}\right), 6.35\left(\mathrm{~d},{ }^{3} \mathrm{~J}_{\mathrm{HH}}=2.5 \mathrm{~Hz}, 1 \mathrm{H}, \mathrm{H}_{\mathrm{Tp}}\right), 6.33\left(\mathrm{~d},{ }^{3} \mathrm{~J}_{\mathrm{HH}}=7.3\right.$ $\left.\mathrm{Hz}, 2 \mathrm{H}, \mathrm{H}_{\mathrm{Ph}}\right), 5.79\left(\mathrm{~d},{ }^{2} J_{\mathrm{HH}}=16.0 \mathrm{~Hz}, 1 \mathrm{H}, \mathrm{H}_{\text {bridge }}\right), 5.74\left(\mathrm{~d},{ }^{2} J_{\mathrm{HH}}=\right.$ $\left.16.0 \mathrm{~Hz}, 1 \mathrm{H}, \mathrm{H}_{\text {bridge }}\right), 5.67\left(\mathrm{~m}, 2 \mathrm{H}, \mathrm{H}_{\mathrm{Tp}}\right) .{ }^{13} \mathrm{C}\left\{{ }^{1} \mathrm{H}\right\} \mathrm{NMR}\left(\mathrm{CD}_{3} \mathrm{NO}_{2}\right.$, $101 \mathrm{MHz}): \delta 204.6(\mathrm{CO}), 177.0\left(\mathrm{C}_{\text {imid }} \mathrm{Ru}\right), 163.3\left(\mathrm{q},{ }^{1} J_{\mathrm{B}-\mathrm{C}}=50.0 \mathrm{~Hz}\right.$, $\left.\mathrm{BAr}_{4}^{\mathrm{F}}\right), 158.1\left(\mathrm{C}_{\mathrm{py}}\right), 157.1\left(\mathrm{C}_{\mathrm{py}}\right), 148.0(\mathrm{Tp}), 145.1(\mathrm{Tp}), 143.9(\mathrm{Tp})$, $141.1\left(\mathrm{C}_{\mathrm{Ph}}\right), 140.5\left(\mathrm{C}_{\mathrm{py}}\right), 137.9(\mathrm{Tp}), 137.5(\mathrm{Tp}), 137.5(\mathrm{Tp}), 136.3$ $\left(\mathrm{BAr}_{4}^{\mathrm{F}}\right), 130.4\left(\mathrm{q},{ }^{2} \mathrm{~J}_{\mathrm{C}-\mathrm{F}}=28.7 \mathrm{~Hz}, \mathrm{BAr}_{4}^{\mathrm{F}}\right), 129.8\left(\mathrm{C}_{\mathrm{Ph}}\right), 129.5\left(\mathrm{C}_{\mathrm{Ph}}\right)$, $126.7\left(\mathrm{C}_{\mathrm{Ph}}\right), 126.4\left(\mathrm{C}_{\mathrm{py}}\right), 126.1\left(\mathrm{C}_{\text {imid }}\right), 126.1\left(\mathrm{q},{ }^{1} J_{\mathrm{C}-\mathrm{F}}=271.9 \mathrm{~Hz}\right.$, $\left.\mathrm{BAr}^{\mathrm{F}}{ }_{4}\right), 124.1\left(\mathrm{C}_{\mathrm{py}}\right), 119.0\left(\mathrm{BAr}_{4}^{\mathrm{F}}\right), 108.5(\mathrm{Tp}), 108.2(\mathrm{Tp}), 108.0$ (Tp), $57.7\left(\mathrm{CH}_{2}\right)$. IR (nujol, $\left.\mathrm{cm}^{-1}\right) \nu(\mathrm{CO})$ 1976. Anal. Calcd. for $\mathrm{C}_{57} \mathrm{H}_{35} \mathrm{~B}_{2} \mathrm{~F}_{24} \mathrm{~N}_{9} \mathrm{ORu}+0.5 \mathrm{Et}_{2} \mathrm{O}: \mathrm{C} 47.96, \mathrm{H}$ 2.73, N 8.53. Found: $\mathrm{C}$ 47.88, H 2.76, N 8.49. 
$\left[T p R u\left(\kappa^{2}-C, N-3-m e t h y l-1-(2-p i c o l y l) b e n z o i m i d a z o l-2-y l i d e n e\right)-\right.$ (CO)][BAr $\left.{ }_{4}\right]$ (2e). [TpRu $\left(\kappa^{2}-C, N\right.$-picolyl- $\left.\left.{ }^{M e} \mathrm{BI}\right) \mathrm{Cl}\right] \quad(114.6 \mathrm{mg}, 0.2$ $\mathrm{mmol})$ and $\mathrm{NaBAr}_{4}^{\mathrm{F}}(177.2 \mathrm{mg}, 0.2 \mathrm{mmol})$ were suspended in 6 $\mathrm{mL}$ of fluorobenzene under $1 \mathrm{~atm}$ of $\mathrm{CO}$, and a red solution was observed. The mixture was stirred for $1 \mathrm{~h}$. The solvent was removed under reduced pressure. The solid was dissolved in $\mathrm{Et}_{2} \mathrm{O}(10 \mathrm{~mL})$ and filtered through a pad of Celite to remove $\mathrm{NaCl}$. The resulting brown solution was layered with petroleum ether to yield brown crystals. Yield: $254.2 \mathrm{mg}(89 \%) .{ }^{1} \mathrm{H}$ NMR $\left(\mathrm{CD}_{3} \mathrm{NO}_{2}, 500 \mathrm{MHz}\right): \delta 8.06(\mathrm{~d}$, $\left.{ }^{3} J_{\mathrm{HH}}=2.4 \mathrm{~Hz}, 1 \mathrm{H}, \mathrm{H}_{\mathrm{Tp}}\right), 8.01\left(\mathrm{~d},{ }^{3} \mathrm{~J}_{\mathrm{HH}}=2.4 \mathrm{~Hz}, 1 \mathrm{H}, \mathrm{H}_{\mathrm{Tp}}\right), 7.99(\mathrm{~d}$, $\left.{ }^{3} J_{\mathrm{HH}}=2.4 \mathrm{~Hz}, 1 \mathrm{H}, \mathrm{H}_{\mathrm{Tp}}\right), 7.87\left(\mathrm{br} \mathrm{s}, 8 \mathrm{H}, \mathrm{BAr}_{4}^{\mathrm{F}}\right), 7.84-7.79(\mathrm{~m}, 3 \mathrm{H}$, $\mathrm{H}_{\mathrm{Tp}}+2 \mathrm{H}_{\text {pyridine }}$ ), $7.78\left(\mathrm{~d},{ }^{3} J_{\mathrm{HH}}=7.9 \mathrm{~Hz}, 1 \mathrm{H}, \mathrm{H}_{\text {benzoimid }}\right), 7.71\left(\mathrm{~d},{ }^{3} \mathrm{~J}_{\mathrm{HH}}\right.$ $\left.=5.5 \mathrm{~Hz}, 1 \mathrm{H}, \mathrm{H}_{\text {pyridine }}\right), 7.68\left(\right.$ br s, $\left.4 \mathrm{H}, \mathrm{BAr}^{\mathrm{F}}{ }_{4}\right), 7.53\left(\mathrm{~d},{ }^{3} J_{\mathrm{HH}}=1.8 \mathrm{~Hz}\right.$, $\left.1 \mathrm{H}, \mathrm{H}_{\mathrm{TP}}\right), 7.38\left(\mathrm{~m}, 1 \mathrm{H}, \mathrm{H}_{\text {benzoimid }}\right), 7.30\left(\mathrm{t},{ }^{3} \mathrm{~J}_{\mathrm{HH}}=7.6 \mathrm{~Hz}, 1 \mathrm{H}\right.$, $\left.\mathrm{H}_{\text {benzoimid }}\right), 7.10\left(\mathrm{t},{ }^{3} J_{\mathrm{HH}}=7.4 \mathrm{~Hz}, 1 \mathrm{H}, \mathrm{H}_{\text {pyridine }}\right), 6.84\left(\mathrm{~d},{ }^{3} \mathrm{~J}_{\mathrm{HH}}=7.9 \mathrm{~Hz}\right.$, $1 \mathrm{H}, \mathrm{H}_{\text {benzoimid }}$ ), $6.47\left(\mathrm{vt},{ }^{3} J_{\mathrm{HH}}=1.8 \mathrm{~Hz}, 1 \mathrm{H}, \mathrm{H}_{\mathrm{Tp}}\right.$ ), $6.33\left(\mathrm{vt},{ }^{3} J_{\mathrm{HH}}=2.4\right.$ $\left.\mathrm{Hz}, 1 \mathrm{H}, \mathrm{H}_{\mathrm{Tp}}\right), 6.16\left(\mathrm{~d},{ }^{3} J_{\mathrm{HH}}=1.8 \mathrm{~Hz}, 1 \mathrm{H}, \mathrm{H}_{\mathrm{Tp}}\right), 6.07\left(\mathrm{vt},{ }^{3} \mathrm{~J}_{\mathrm{HH}}=1.8\right.$ $\left.\mathrm{Hz}, 1 \mathrm{H}, \mathrm{H}_{\mathrm{Tp}}\right), 5.98\left(\mathrm{~d},{ }^{2} J_{\mathrm{HH}}=15.9 \mathrm{~Hz}, 1 \mathrm{H}, \mathrm{H}_{\text {bridge }}\right), 5.17\left(\mathrm{~d},{ }^{2} J_{\mathrm{HH}}=\right.$ $\left.16.5 \mathrm{~Hz}, 1 \mathrm{H}, \mathrm{H}_{\text {bridge }}\right), 2.68\left(\mathrm{~s}, 3 \mathrm{H}, \mathrm{NCH}_{3}\right) .{ }^{13} \mathrm{C}\left\{{ }^{1} \mathrm{H}\right\} \mathrm{NMR}\left(\mathrm{CD}_{3} \mathrm{NO}_{2}\right.$, $125 \mathrm{MHz}): \delta 205.9(\mathrm{CO}), 168.6\left(\mathrm{C}_{\text {benzoimid }} \mathrm{Ru}\right), 163.2\left(\mathrm{q},{ }^{1} J_{\mathrm{B}-\mathrm{C}}=49.9\right.$ $\left.\mathrm{Hz}, \mathrm{BAr}_{4}^{\mathrm{F}}\right), 160.0\left(\mathrm{C}_{\mathrm{py}}\right), 158.2\left(\mathrm{C}_{\mathrm{py}}\right), 147.6(\mathrm{Tp}), 146.1(\mathrm{Tp}), 144.9$ (Tp), $138.5(\mathrm{Tp}), 138.3(\mathrm{Tp}), 137.9$ ( $\left.\mathrm{C}_{\text {benzoimid }}\right), 137.7(\mathrm{Tp}), 137.2$ $\left(\mathrm{C}_{\mathrm{py}}\right), 136.2\left(\mathrm{BAr}_{4}^{\mathrm{F}}\right), 136.1\left(\mathrm{C}_{\text {benzoimid }}\right), 130.3\left(\mathrm{q},{ }^{2} \mathrm{~J}_{\mathrm{C}-\mathrm{F}}=31.4 \mathrm{~Hz}\right.$, $\left.\mathrm{BAr}^{\mathrm{F}}\right), 126.0\left(\mathrm{q},{ }^{1} J_{\mathrm{C}-\mathrm{F}}=271.26 \mathrm{~Hz}, \mathrm{BAr}^{\mathrm{F}}{ }_{4}\right), 125.61\left(\mathrm{C}_{\mathrm{py}}\right), 125.3$ $\left(\mathrm{C}_{\mathrm{py}}\right), 123.7$ ( $\left.\mathrm{C}_{\text {benzoimid }}\right), 123.5\left(\mathrm{C}_{\text {benzoimid }}\right), 119.0\left(\mathrm{BAr}_{4}^{\mathrm{F}}\right), 110.5$ $\left(\mathrm{C}_{\text {benzoimid }}\right), 109.6\left(\mathrm{C}_{\text {benzoimid }}\right), 108.4(\mathrm{Tp}), 107.9(\mathrm{Tp}), 107.8(\mathrm{Tp})$, $51.6\left(\mathrm{CH}_{2}\right), 32.9\left(\mathrm{NCH}_{3}\right)$. IR (nujol, cm $\left.{ }^{-1}\right) \nu(\mathrm{CO})$ 1976. Anal. Calcd. for $\mathrm{C}_{56} \mathrm{H}_{35} \mathrm{~B}_{2} \mathrm{~F}_{24} \mathrm{~N}_{9} \mathrm{ORu}$ : C 47.08, H 2.47, N 8.82. Found: C 47.03, $\mathrm{H}$ 2.38, N 9.01.

[\{TpRu( $\left.\left.\left.\kappa^{2}-C, N-3-m e t h y l-1-(2-p i c o l y l) i m i d a z o l-2-y l i d e n e\right)\right\}_{2}\left(\mu-N_{2}\right)\right]-$ $\left[B A r_{4}^{F}\right]_{2}\left(3 a-3^{\prime} a\right) . \quad\left[\mathrm{TpRu}\left(\kappa^{2}-C, N\right.\right.$-picolyl $\left.\left.{ }^{\mathrm{Me}} \mathrm{I}\right) \mathrm{Cl}\right] \quad(105.5 \mathrm{mg}, 0.2$ $\mathrm{mmol})$ and $\mathrm{NaBAr}_{4}^{\mathrm{F}}(177.2 \mathrm{mg}, 0.2 \mathrm{mmol})$ were suspended in 6 $\mathrm{mL}$ of fluorobenzene under $1 \mathrm{~atm}$ of $\mathrm{N}_{2}$, and a dark yellow solution was observed. The mixture was stirred for $1 \mathrm{~h}$. The solvent was removed under reduced pressure. The solid was dissolved in $\mathrm{Et}_{2} \mathrm{O}$ (10 $\mathrm{mL}$ ) and filtered through a pad of Celite to remove $\mathrm{NaCl}$. The resulting yellow solution was layered with petroleum ether to yield yellow crystals. Yield: $496.7 \mathrm{mg}(91 \%) .{ }^{1} \mathrm{H} \mathrm{NMR}\left(\mathrm{CD}_{2} \mathrm{Cl}_{2}, 400 \mathrm{MHz}\right)$ : $\delta 7.97\left(\mathrm{dd},{ }^{3} J_{\mathrm{HH}}=2.4,0.6 \mathrm{~Hz}, 1 \mathrm{H}, \mathrm{H}_{\mathrm{Tp}}\right), 7.93\left(\mathrm{~m}, 1 \mathrm{H}, \mathrm{H}_{\mathrm{Tp}}\right), 7.89(\mathrm{~m}$, $\left.2 \mathrm{H}, \mathrm{H}_{\mathrm{Tp}}\right), 7.85\left(\mathrm{~m}, 1 \mathrm{H}, \mathrm{H}_{\text {pyridine }}\right), 7.80\left(\mathrm{~m}, 2 \mathrm{H}, \mathrm{H}_{\text {pyridine }}+\mathrm{H}_{\mathrm{Tp}}\right), 7.74$ (br s, $\left.16 \mathrm{H}, \mathrm{BAr}^{\mathrm{F}}{ }_{4}\right), 7.71\left(\mathrm{~m}, 1 \mathrm{H}, \mathrm{H}_{\text {pyridine }}\right), 7.57\left(\mathrm{br} \mathrm{s}, 8 \mathrm{H}, \mathrm{BAr}^{\mathrm{F}}{ }_{4}\right), 7.52$ $\left(\mathrm{m}, 1 \mathrm{H}, \mathrm{H}_{\text {pyridine }}\right), 7.38\left(\mathrm{~m}, 1 \mathrm{H}, \mathrm{H}_{\mathrm{Tp}}\right), 7.24\left(\mathrm{~m}, 2 \mathrm{H}, \mathrm{H}_{\text {pyridine }}\right), 7.13(\mathrm{t}$, $\left.{ }^{3} J_{\mathrm{HH}}=6.7 \mathrm{~Hz}, 1 \mathrm{H}, \mathrm{H}_{\text {pyridine }}\right), 7.08\left(\mathrm{~d},{ }^{3} \mathrm{~J}_{\mathrm{HH}}=1.4 \mathrm{~Hz}, 1 \mathrm{H}, \mathrm{H}_{\mathrm{Tp}}\right), 7.05$ $\left(\mathrm{m}, 1 \mathrm{H}, \mathrm{H}_{\text {pyridine }}\right), 7.02\left(\mathrm{~d},{ }^{3} J_{\mathrm{HH}}=2.1 \mathrm{~Hz}, 1 \mathrm{H}, \mathrm{H}_{\text {imid }}\right), 7.01\left(\mathrm{~d},{ }^{3} \mathrm{~J}_{\mathrm{HH}}=\right.$ $\left.2.1 \mathrm{~Hz}, 1 \mathrm{H}, \mathrm{H}_{\text {imid }}\right), 7.00\left(\mathrm{~d},{ }^{3} J_{\mathrm{HH}}=2.0 \mathrm{~Hz}, 1 \mathrm{H}, \mathrm{H}_{\mathrm{Tp}}\right), 6.91\left(\mathrm{~d},{ }^{3} \mathrm{~J}_{\mathrm{HH}}=\right.$ $\left.1.9 \mathrm{~Hz}, 1 \mathrm{H}, \mathrm{H}_{\mathrm{Tp}}\right), 6.85\left(\mathrm{~d},{ }^{3} \mathrm{~J}_{\mathrm{HH}}=2.1 \mathrm{~Hz}, 1 \mathrm{H}, \mathrm{H}_{\mathrm{imid}}\right), 6.82\left(\mathrm{~m}, 2 \mathrm{H}, \mathrm{H}_{\mathrm{Tp}}\right.$ $+\mathrm{H}_{\text {imid }}$ ), $6.39\left(\mathrm{~m}, 1 \mathrm{H}, \mathrm{H}_{\mathrm{Tp}}\right), 6.29\left(\mathrm{vt},{ }^{3} \mathrm{~J}_{\mathrm{HH}}=2.1 \mathrm{~Hz}, 1 \mathrm{H}, \mathrm{H}_{\mathrm{Tp}}\right), 6.25$ $\left(\mathrm{m}, 1 \mathrm{H}, \mathrm{H}_{\mathrm{Tp}}\right), 6.20\left(\mathrm{vt},{ }^{3} J_{\mathrm{HH}}=2.3 \mathrm{~Hz}, 1 \mathrm{H}, \mathrm{H}_{\mathrm{Tp}}\right), 6.13\left(\mathrm{vt},{ }^{3} \mathrm{~J}_{\mathrm{HH}}=2.1\right.$ $\left.\mathrm{Hz}, 1 \mathrm{H}, \mathrm{H}_{\mathrm{Tp}}\right), 6.10\left(\mathrm{~m}, 2 \mathrm{H}, \mathrm{H}_{\mathrm{Tp}}\right), 6.03\left(\mathrm{~m}, 1 \mathrm{H}, \mathrm{H}_{\mathrm{Tp}}\right), 5.83(\mathrm{~m}, 1 \mathrm{H}$, $\left.\mathrm{H}_{\mathrm{Tp}}\right), 4.58\left(\mathrm{~d},{ }^{2} J_{\mathrm{HH}}=16.3 \mathrm{~Hz}, 2 \mathrm{H}, \mathrm{H}_{\text {bridge }}\right), 4.26\left(\mathrm{~m}, 2 \mathrm{H}, \mathrm{H}_{\text {bridge }}\right), 2.43$ $\left(\mathrm{s}, 3 \mathrm{H}, \mathrm{NCH}_{3}\right), 2.39\left(\mathrm{~s}, 3 \mathrm{H}, \mathrm{NCH}_{3}\right) \cdot{ }^{13} \mathrm{C}\left\{{ }^{1} \mathrm{H}\right\}$ NMR $\left(\mathrm{CD}_{2} \mathrm{Cl}_{2}, 101\right.$ $\mathrm{MHz}): \delta 180.5\left(\mathrm{C}_{\text {imid }} \mathrm{Ru}\right), 180.4\left(\mathrm{C}_{\text {imid }} \mathrm{Ru}\right), 162.2\left(\mathrm{q},{ }^{1} J_{\mathrm{B}-\mathrm{C}}=50.2 \mathrm{~Hz}\right.$, $\left.\mathrm{BAr}_{4}{ }_{4}\right), 156.8\left(\mathrm{C}_{\mathrm{py}}\right), 156.7\left(\mathrm{C}_{\mathrm{py}}\right), 156.5\left(\mathrm{C}_{\mathrm{py}}\right), 156.4\left(\mathrm{C}_{\mathrm{py}}\right), 143.7(\mathrm{Tp})$, $143.3(\mathrm{Tp}), 143.2(\mathrm{Tp}), 141.6(\mathrm{Tp}), 141.1(\mathrm{Tp}), 138.9\left(\mathrm{C}_{\mathrm{py}}\right), 137.9$ $\left(\mathrm{C}_{\mathrm{py}}\right), 137.8(\mathrm{Tp}), 137.7(\mathrm{Tp}), 137.7(\mathrm{Tp}), 137.1(\mathrm{Tp}), 135.2\left(\mathrm{BAr}_{4}^{\mathrm{F}}\right)$, $129.3\left(\mathrm{q},{ }^{2} J_{\mathrm{C}-\mathrm{F}}=32.8 \mathrm{~Hz}, \mathrm{BAr}^{\mathrm{F}}\right), 125.6\left(\mathrm{C}_{\text {imid }}\right), 125.6\left(\mathrm{C}_{\text {imid }}\right), 125.3$ $\left(\mathrm{C}_{\text {imid }}\right), 125.3\left(\mathrm{C}_{\text {imid }}\right), 125.0\left(\mathrm{q},{ }^{1} J_{\mathrm{C}-\mathrm{F}}=275.9 \mathrm{~Hz}, \mathrm{BAr}_{4}^{\mathrm{F}}\right), 124.3\left(\mathrm{C}_{\mathrm{py}}\right)$, $124.3\left(\mathrm{C}_{\mathrm{py}}\right), 122.7\left(\mathrm{C}_{\mathrm{py}}\right), 122.7\left(\mathrm{C}_{\mathrm{py}}\right), 117.9\left(\mathrm{BAr}_{4}{ }_{4}\right), 107.8(\mathrm{Tp})$, $107.7(\mathrm{Tp}), 107.7(\mathrm{Tp}), 107.6(\mathrm{Tp}), 54.3\left(\mathrm{CH}_{2}\right), 54.3\left(\mathrm{CH}_{2}\right), 35.9$ $\left(\mathrm{NCH}_{3}\right)$, $35.9\left(\mathrm{NCH}_{3}\right)$. Anal. Calcd. for $\mathrm{C}_{102} \mathrm{H}_{66} \mathrm{~B}_{4} \mathrm{~F}_{48} \mathrm{~N}_{20} \mathrm{Ru}_{2}$ : C 44.89, H 2.44, N 10.26. Found: C 44.85, H 2.46, N 10.28.

[\{TpRu $\left(\kappa^{2}-C, N\right.$-3-isopropyl-1-(2-picolyl)imidazol-2-ylidene $\left.)\right\}_{2}(\mu$ $\left.\left.N_{2}\right)\right]\left[B A r_{4}^{F}\right]_{2}(3 b) .\left[\mathrm{TpRu}\left(\kappa^{2}-C, N\right.\right.$-picolyl- $\left.\left.{ }^{i{ }^{\prime} \mathrm{I}}\right) \mathrm{Cl}\right](110.2 \mathrm{mg}, 0.2 \mathrm{mmol})$ and $\mathrm{NaBAr}_{4}^{\mathrm{F}}(177.2 \mathrm{mg}, 0.2 \mathrm{mmol})$ were suspended in $6 \mathrm{~mL}$ of fluorobenzene under $1 \mathrm{~atm}$ of $\mathrm{N}_{2}$, and an orange solution was observed. The mixture was stirred for $1 \mathrm{~h}$. The solvent was removed under reduced pressure. The solid was dissolved in $\mathrm{Et}_{2} \mathrm{O}(10 \mathrm{~mL})$ and filtered through a pad of Celite to remove $\mathrm{NaCl}$. The resulting dark yellow solution was layered with petroleum ether to yield yellow crystals. Yield: $518.1 \mathrm{mg}$ (93\%). ${ }^{1} \mathrm{H}$ NMR $\left(\mathrm{CD}_{2} \mathrm{Cl}_{2}, 400 \mathrm{MHz}\right): \delta$ $7.93-7.90\left(\mathrm{~m}, 3 \mathrm{H}, \mathrm{H}_{\mathrm{Tp}}\right), 7.75\left(\mathrm{br} \mathrm{s}, 8 \mathrm{H}, \mathrm{BAr}_{4}{ }_{4}\right), 7.72\left(\mathrm{t},{ }^{3} J_{\mathrm{HH}}=7.6 \mathrm{~Hz}\right.$, $\left.1 \mathrm{H}, \mathrm{H}_{\text {pyridine }}\right), 7.57\left(\mathrm{br} \mathrm{s}, 4 \mathrm{H}, \mathrm{BAr}_{4}^{\mathrm{F}}\right), 7.44\left(\mathrm{~d},{ }^{3} J_{\mathrm{HH}}=5.90 \mathrm{~Hz}, 1 \mathrm{H}\right.$, $\left.\mathrm{H}_{\text {pyridine }}\right), 7.22\left(\mathrm{~d},{ }^{3} J_{\mathrm{HH}}=7.3 \mathrm{~Hz}, 1 \mathrm{H}, \mathrm{H}_{\text {pyridine }}\right), 7.18\left(\mathrm{~d},{ }^{3} J_{\mathrm{HH}}=2.0 \mathrm{~Hz}\right.$, $\left.1 \mathrm{H}, \mathrm{H}_{\text {imid }}\right), 7.04\left(\mathrm{~m}, 1 \mathrm{H}, \mathrm{H}_{\text {pyridine }}\right), 7.01\left(\mathrm{~d},{ }^{3} J_{\mathrm{HH}}=2.0 \mathrm{~Hz}, 1 \mathrm{H}, \mathrm{H}_{\text {imid }}\right)$, $6.86\left(\mathrm{~d},{ }^{3} J_{\mathrm{HH}}=1.8 \mathrm{~Hz}, 1 \mathrm{H}, \mathrm{H}_{\mathrm{Tp}}\right), 6.84\left(\mathrm{~d},{ }^{3} \mathrm{~J}_{\mathrm{HH}}=2.0 \mathrm{~Hz}, 1 \mathrm{H}, \mathrm{H}_{\mathrm{Tp}}\right)$, $6.18\left(\mathrm{~d},{ }^{3} \mathrm{~J}_{\mathrm{HH}}=2.0 \mathrm{~Hz}, 1 \mathrm{H}, \mathrm{H}_{\mathrm{Tp}}\right), 6.15\left(\mathrm{vt},{ }^{3} \mathrm{~J}_{\mathrm{HH}}=2.2 \mathrm{~Hz}, 1 \mathrm{H}, \mathrm{H}_{\mathrm{Tp}}\right)$, $6.13-6.10\left(\mathrm{~m}, 2 \mathrm{H}, \mathrm{H}_{\mathrm{Tp}}\right), 4.56\left(\mathrm{~d},{ }^{2} J_{\mathrm{HH}}=16.1 \mathrm{~Hz}, 1 \mathrm{H}, \mathrm{H}_{\text {bridge }}\right), 4.23(\mathrm{~d}$, $\left.{ }^{2} J_{\mathrm{HH}}=16.1 \mathrm{~Hz}, 1 \mathrm{H}, \mathrm{H}_{\text {bridge }}\right), 2.84(\mathrm{~m}, 1 \mathrm{H}, \mathrm{CH}), 0.93\left(\mathrm{~d},{ }^{3} J_{\mathrm{HH}}=6.8 \mathrm{~Hz}\right.$, $\left.3 \mathrm{H}, \mathrm{CH}_{3}\right), 0.67\left(\mathrm{~d},{ }^{3} J_{\mathrm{HH}}=6.8 \mathrm{~Hz}, 3 \mathrm{H}, \mathrm{CH}_{3}\right) .{ }^{13} \mathrm{C}\left\{{ }^{1} \mathrm{H}\right\} \mathrm{NMR}\left(\mathrm{CD}_{2} \mathrm{Cl}_{2}\right.$, $101 \mathrm{MHz}): \delta 178.3\left(\mathrm{C}_{\text {imid }} \mathrm{Ru}\right), 162.1\left(\mathrm{q},{ }^{1} J_{\mathrm{B}-\mathrm{C}}=49.6 \mathrm{~Hz}, \mathrm{BAr}^{\mathrm{F}}\right), 156.7$ $\left(\mathrm{C}_{\mathrm{py}}\right), 156.5\left(\mathrm{C}_{\mathrm{py}}\right), 144.1(\mathrm{Tp}), 143.6(\mathrm{Tp}), 140.96(\mathrm{Tp}), 138.9\left(\mathrm{C}_{\mathrm{py}}\right)$, $138.1(\mathrm{Tp}), 137.1(\mathrm{Tp}), 135.2\left(\mathrm{BAr}_{4}^{\mathrm{F}}\right), 129.3\left(\mathrm{q},{ }^{2} J_{\mathrm{C}-\mathrm{F}}=32.0 \mathrm{~Hz}\right.$, $\left.\mathrm{BAr}^{\mathrm{F}}{ }_{4}\right), 125.6\left(\mathrm{C}_{\mathrm{py}}\right), 125.2\left(\mathrm{C}_{\mathrm{py}}\right), 125.0\left(\mathrm{q},{ }^{1} \mathrm{~J}_{\mathrm{C}-\mathrm{F}}=272.4 \mathrm{~Hz}, \mathrm{BAr}_{4}{ }_{4}\right)$, $123.5\left(\mathrm{C}_{\text {imid }}\right), 118.8\left(\mathrm{C}_{\text {imid }}\right), 117.9\left(\mathrm{BAr}_{4}^{\mathrm{F}}\right), 107.7(\mathrm{Tp}), 107.5(\mathrm{Tp})$, $107.4(\mathrm{Tp}), 54.2\left(\mathrm{CH}_{2}\right), 50.9(\mathrm{NCH}), 24.4\left(\mathrm{CH}_{3}\right), 22.1\left(\mathrm{CH}_{3}\right)$. Anal. Calcd. for $\mathrm{C}_{106} \mathrm{H}_{74} \mathrm{~B}_{4} \mathrm{~F}_{48} \mathrm{~N}_{20} \mathrm{Ru}_{2}$ : C 45.71, $\mathrm{H} \mathrm{2.68,} \mathrm{N} \mathrm{10.06.} \mathrm{Found:} \mathrm{C}$ 45.80, H 2.74, N 9.99 .

$\Delta, \Lambda-\left[\left\{T p R u\left(\kappa^{2}-C, N-3-p h e n y l-1-(2-p i c o l y l) i m i d a z o l-2-y l i d e n e\right)\right\}_{2}(\mu-\right.$ $\left.\left.\mathrm{N}_{2}\right)\right]\left[\mathrm{BAr}_{4}^{\mathrm{F}}\right]_{2} \cdot 2 \mathrm{Et}{ }_{2} \mathrm{O}\left(\mathbf{3}^{\prime} \boldsymbol{d}\right)$. $\left[\mathrm{TpRu}\left(\kappa^{2}-C, N\right.\right.$-picolyl- $\left.\left.{ }^{P h} \mathrm{I}\right) \mathrm{Cl}\right](117.0 \mathrm{mg}, 0.2$ $\mathrm{mmol})$ and $\mathrm{NaBAr}_{4}{ }_{4}(177.2 \mathrm{mg}, 0.2 \mathrm{mmol})$ were suspended in $6 \mathrm{~mL}$ of fluorobenzene under $1 \mathrm{~atm}$ of $\mathrm{N}_{2}$, and a dark yellow solution was observed. The mixture was stirred for $1 \mathrm{~h}$. The solvent was removed under reduced pressure. The solid was dissolved in $\mathrm{Et}_{2} \mathrm{O}(10 \mathrm{~mL})$ and filtered through a pad of Celite to remove $\mathrm{NaCl}$. The resulting yellow solution was layered with petroleum ether to yield yellow crystals. Yield: $573.6 \mathrm{mg}(82 \%) .{ }^{1} \mathrm{H}$ NMR $\left(\mathrm{CD}_{2} \mathrm{Cl}_{2}, 500 \mathrm{MHz}\right): \delta 7.91\left(\mathrm{~d},{ }^{3} \mathrm{~J}_{\mathrm{HH}}\right.$ $\left.=2.3 \mathrm{~Hz}, 1 \mathrm{H}, \mathrm{H}_{\mathrm{Tp}}\right), 7.87\left(\mathrm{~d},{ }^{3} J_{\mathrm{HH}}=2.3 \mathrm{~Hz}, 1 \mathrm{H}, \mathrm{H}_{\mathrm{Tp}}\right), 7.77\left(\mathrm{t},{ }^{3} J_{\mathrm{HH}}=\right.$ $\left.7.8 \mathrm{~Hz}, 1 \mathrm{H}, \mathrm{H}_{\text {pyridine }}\right), 7.72$ (br s, $8 \mathrm{H}, \mathrm{BAr}_{4}^{\mathrm{F}}$ ), 7.55 (br s, $4 \mathrm{H}_{1} \mathrm{BAr}^{\mathrm{F}}{ }_{4}$ ), $7.48\left(\mathrm{~d},{ }^{3} \mathrm{~J}_{\mathrm{HH}}=5.8 \mathrm{~Hz}, 1 \mathrm{H}, \mathrm{H}_{\text {pyridine }}\right), 7.46\left(\mathrm{~d},{ }^{3} \mathrm{~J}_{\mathrm{HH}}=2.3 \mathrm{~Hz}, 1 \mathrm{H}, \mathrm{H}_{\mathrm{Tp}}\right)$, $7.24\left(\mathrm{~d},{ }^{3} J_{\mathrm{HH}}=7.5 \mathrm{~Hz}, 1 \mathrm{H}, \mathrm{H}_{\text {pyridine }}\right), 7.12\left(\mathrm{~d},{ }^{3} J_{\mathrm{HH}}=2.2 \mathrm{~Hz}, 1 \mathrm{H}\right.$, $\left.\mathrm{H}_{\text {imid }}\right), 7.10\left(\mathrm{~m}, 1 \mathrm{H}, \mathrm{H}_{\text {pyridine }}\right), 7.08\left(\mathrm{~d},{ }^{3} J_{\mathrm{HH}}=1.8 \mathrm{~Hz}, 1 \mathrm{H}, \mathrm{H}_{\text {imid }}\right), 6.97$ $\left(\mathrm{m}, 1 \mathrm{H}, \mathrm{H}_{\mathrm{Tp}}\right), 6.87\left(\mathrm{t},{ }^{3} J_{\mathrm{HH}}=7.8 \mathrm{~Hz}, 1 \mathrm{H}, \mathrm{H}_{\mathrm{Ph}}\right), 6.80\left(\mathrm{t},{ }^{3} \mathrm{~J}_{\mathrm{HH}}=7.8 \mathrm{~Hz}\right.$, $\left.2 \mathrm{H}, \mathrm{H}_{\mathrm{Ph}}\right), 6.29\left(\mathrm{~m}, 2 \mathrm{H}, \mathrm{H}_{\mathrm{Tp}}\right), 6.25\left(\mathrm{vt},{ }^{3} \mathrm{~J}_{\mathrm{HH}}=2.0 \mathrm{~Hz}, 1 \mathrm{H}, \mathrm{H}_{\mathrm{Tp}}\right), 6.23$ $\left(\mathrm{d},{ }^{3} \mathrm{~J}_{\mathrm{HH}}=1.7 \mathrm{~Hz}, 1 \mathrm{H}, \mathrm{H}_{\mathrm{Tp}}\right), 6.08\left(\mathrm{~d},{ }^{3} J_{\mathrm{HH}}=7.5 \mathrm{~Hz}, 2 \mathrm{H}, \mathrm{H}_{\mathrm{Ph}}\right.$ ), 5.45 (vt, $\left.{ }^{3} J_{\mathrm{HH}}=2.0 \mathrm{~Hz}, 1 \mathrm{H}, \mathrm{H}_{\mathrm{Tp}}\right), 4.60\left(\mathrm{~d},{ }^{2} J_{\mathrm{HH}}=15.6 \mathrm{~Hz}, 1 \mathrm{H}, \mathrm{H}_{\text {bridge }}\right), 4.18(\mathrm{~d}$, $\left.{ }^{2} J_{\mathrm{HH}}=16.1 \mathrm{~Hz}, 1 \mathrm{H}, \mathrm{H}_{\text {bridge }}\right) .{ }^{13} \mathrm{C}\left\{{ }^{1} \mathrm{H}\right\} \operatorname{NMR}\left(\mathrm{CD}_{2} \mathrm{Cl}_{2}, 125 \mathrm{MHz}\right): \delta$ $179.8\left(\mathrm{C}_{\text {imid }} \mathrm{Ru}\right), 162.1\left(\mathrm{q},{ }_{1}^{1} \mathrm{~J}_{\mathrm{B}-\mathrm{C}}=49.9 \mathrm{~Hz}, \mathrm{BAr}_{4}^{\mathrm{F}}\right), 156.8\left(\mathrm{C}_{\mathrm{py}}\right), 156.0$ $\left(\mathrm{C}_{\mathrm{py}}\right), 143.8(\mathrm{Tp}), 143.6(\mathrm{Tp}), 140.9(\mathrm{Tp}), 139.1\left(\mathrm{C}_{\mathrm{py}}\right), 139.0\left(\mathrm{C}_{\mathrm{Ph}}\right)$, $137.9(\mathrm{Tp}), 137.0(\mathrm{Tp}), 136.8(\mathrm{Tp}), 135.2\left(\mathrm{BAr}_{4}^{\mathrm{F}}\right), 129.3\left(\mathrm{q},{ }^{2} J_{\mathrm{C}-\mathrm{F}}=\right.$ $\left.31.8 \mathrm{~Hz}, \mathrm{BAr}_{4}^{\mathrm{F}}\right), 129.0\left(\mathrm{C}_{\mathrm{Ph}}\right), 125.9\left(\mathrm{C}_{\mathrm{py}}\right), 125.8\left(\mathrm{C}_{\text {imid }}\right), 125.2\left(\mathrm{C}_{\mathrm{py}}\right)$, $125.1\left(\mathrm{C}_{\mathrm{Ph}}\right), 125.0\left(\mathrm{q},{ }^{1} J_{\mathrm{C}-\mathrm{F}}=272.5 \mathrm{~Hz}, \mathrm{BAr}_{4}{ }_{4}\right), 123.0\left(\mathrm{C}_{\mathrm{Ph}}\right), 122.9$ $\left(\mathrm{C}_{\text {imid }}\right), 117.9\left(\mathrm{BAr}_{4}^{\mathrm{F}}\right), 108.3(\mathrm{Tp}), 107.6(\mathrm{Tp}), 107.1(\mathrm{Tp})$, 54.6 $\left(\mathrm{CH}_{2}\right)$. Anal. Calcd. for $\mathrm{C}_{112} \mathrm{H}_{70} \mathrm{~B}_{4} \mathrm{~F}_{48} \mathrm{~N}_{20} \mathrm{Ru}_{2}+2 \mathrm{Et}_{2} \mathrm{O}: \mathrm{C}$ 48.02, H 3.02, N 9.33. Found: C 48.15, H 2.99, N 9.30.

$\Delta, \Delta$ - $\left[\left\{T p R u\left(\kappa^{2}-C, N-3 \text {-phenyl-1-(2-picolyl)imidazol-2-ylidene) }\right\}_{2}(\mu\right.\right.$ $\left.\left.N_{2}\right)\right]\left[B A r_{4}^{F}\right]_{2}(3 d) .{ }^{1} \mathrm{H}$ NMR $\left(\mathrm{CD}_{2} \mathrm{Cl}_{2}, 500 \mathrm{MHz}\right): \delta 7.90\left(\mathrm{~d},{ }^{3} \mathrm{~J}_{\mathrm{HH}}=2.5\right.$ $\left.\mathrm{Hz}, 1 \mathrm{H}, \mathrm{H}_{\mathrm{Tp}}\right), 7.82\left(\mathrm{~d},{ }^{3} \mathrm{~J}_{\mathrm{HH}}=2.9 \mathrm{~Hz}, 1 \mathrm{H}, \mathrm{H}_{\mathrm{Tp}}\right), 7.72\left(\mathrm{br} \mathrm{s}, 9 \mathrm{H}, \mathrm{BAr}^{\mathrm{F}}\right.$ $\left.+\mathrm{H}_{\text {pyridine }}\right), 7.65\left(\mathrm{t},{ }^{3} \mathrm{~J}_{\mathrm{HH}}=6.2 \mathrm{~Hz}, 1 \mathrm{H}, \mathrm{H}_{\text {pyridine }}\right), 7.55(\mathrm{br} \mathrm{s}, 4 \mathrm{H}$, $\left.\mathrm{BAr}_{4}^{\mathrm{F}}\right), 7.50\left(\mathrm{~d},{ }^{3} \mathrm{~J}_{\mathrm{HH}}=2.0 \mathrm{~Hz}, 1 \mathrm{H}, \mathrm{H}_{\mathrm{Tp}}\right), 7.43\left(\mathrm{~d},{ }^{3} J_{\mathrm{HH}}=5.8 \mathrm{~Hz}, 1 \mathrm{H}\right.$, $\left.\mathrm{H}_{\text {pyridine }}\right), 7.26\left(\mathrm{~d},{ }^{3} \mathrm{~J}_{\mathrm{HH}}=8.8 \mathrm{~Hz}, 1 \mathrm{H}, \mathrm{H}_{\text {pyridine }}\right), 7.11\left(\mathrm{~d},{ }^{3} \mathrm{~J}_{\mathrm{HH}}=2.0 \mathrm{~Hz}\right.$, $\left.1 \mathrm{H}, \mathrm{H}_{\text {imid }}\right), 7.07\left(\mathrm{~d},{ }^{3} J_{\mathrm{HH}}=1.9 \mathrm{~Hz}, 1 \mathrm{H}, \mathrm{H}_{\text {imid }}\right), 7.05\left(\mathrm{~m}, 1 \mathrm{H}, \mathrm{H}_{\mathrm{Ph}}\right), 6.86$ $\left(\mathrm{t},{ }^{3} J_{\mathrm{HH}}=7.8 \mathrm{~Hz}, 2 \mathrm{H}, \mathrm{H}_{\mathrm{Ph}}\right), 6.33\left(\mathrm{~d},{ }^{3} J_{\mathrm{HH}}=1.5 \mathrm{~Hz}, 1 \mathrm{H}, \mathrm{H}_{\mathrm{Tp}}\right), 6.28(\mathrm{~m}$, $\left.1 \mathrm{H}, \mathrm{H}_{\mathrm{Tp}}\right), 6.24\left(\mathrm{~m}, 2 \mathrm{H}, \mathrm{H}_{\mathrm{Tp}}\right), 6.12\left(\mathrm{~d},{ }^{3} J_{\mathrm{HH}}=7.5 \mathrm{~Hz}, 2 \mathrm{H}, \mathrm{H}_{\mathrm{Ph}}\right), 6.09$ $\left(\mathrm{m}, 1 \mathrm{H}, \mathrm{H}_{\mathrm{Tp}}\right), 5.68\left(\mathrm{vt},{ }^{3} \mathrm{~J}_{\mathrm{HH}}=2.5 \mathrm{~Hz}, 1 \mathrm{H}, \mathrm{H}_{\mathrm{Tp}}\right), 4.62\left(\mathrm{~d},{ }^{2} J_{\mathrm{HH}}=16.1\right.$ $\left.\mathrm{Hz}, 1 \mathrm{H}, \mathrm{H}_{\text {bridge }}\right), 4.20\left(\mathrm{~d},{ }^{2} J_{\mathrm{HH}}=16.1 \mathrm{~Hz}, 1 \mathrm{H}, \mathrm{H}_{\text {bridge }}\right) .{ }^{13} \mathrm{C}\left\{{ }^{1} \mathrm{H}\right\} \mathrm{NMR}$ $\left(\mathrm{CD}_{2} \mathrm{Cl}_{2}, 125 \mathrm{MHz}\right): \delta 179.9\left(\mathrm{C}_{\text {imid }} \mathrm{Ru}\right), 162.1\left(\mathrm{q},{ }^{1} J_{\mathrm{B}-\mathrm{C}}=49.9 \mathrm{~Hz}\right.$, $\left.\mathrm{BAr}^{\mathrm{F}}{ }_{4}\right), 156.8\left(\mathrm{C}_{\mathrm{py}}\right), 156.0\left(\mathrm{C}_{\mathrm{py}}\right), 143.7(\mathrm{Tp}), 143.6(\mathrm{Tp}), 140.8(\mathrm{Tp})$, $139.1\left(\mathrm{C}_{\mathrm{py}}\right), 139.0\left(\mathrm{C}_{\mathrm{Ph}}\right), 137.9(\mathrm{Tp}), 136.9(\mathrm{Tp}), 136.8(\mathrm{Tp}), 135.2$ $\left(\mathrm{BAr}_{4}^{\mathrm{F}}\right), 129.3\left(\mathrm{q},{ }^{2} J_{\mathrm{C}-\mathrm{F}}=31.8 \mathrm{~Hz}, \mathrm{BAr}^{\mathrm{F}}{ }_{4}\right), 129.0\left(\mathrm{C}_{\mathrm{Ph}}\right), 125.7\left(\mathrm{C}_{\mathrm{py}}\right)$, $125.7\left(\mathrm{C}_{\mathrm{imid}}\right), 125.3\left(\mathrm{C}_{\mathrm{py}}\right), 125.1\left(\mathrm{C}_{\mathrm{Ph}}\right), 125.0\left(\mathrm{q},{ }^{1} J_{\mathrm{C}-\mathrm{F}}=272.5 \mathrm{~Hz}\right.$, $\left.\mathrm{BAr}_{4}^{\mathrm{F}}\right), 122.8\left(\mathrm{C}_{\mathrm{Ph}}\right), 120.9\left(\mathrm{C}_{\text {imid }}\right), 117.9\left(\mathrm{BAr}_{4}^{\mathrm{F}}\right), 107.6(\mathrm{Tp}), 107.2$ (Tp), $107.1(\mathrm{Tp}), 54.5\left(\mathrm{CH}_{2}\right)$.

[TpRu( $\kappa^{2}-\mathrm{C}, \mathrm{N}-3$-methyl-1-(2-picolyl)imidazol-2-ylidene) $\left.\left(\mathrm{CH}_{3} \mathrm{CN}\right)\right]$ $\left[\mathrm{BAr}_{4}\right](4 a)$. [TpRu$\left(\kappa^{2}-C, N\right.$-picolyl- $\left.\left.{ }^{\mathrm{Me}} \mathrm{I}\right) \mathrm{Cl}\right](105.5 \mathrm{mg}, 0.2 \mathrm{mmol})$ and $\mathrm{NaBAr}_{4}^{\mathrm{F}}(177.2 \mathrm{mg}, 0.2 \mathrm{mmol})$ were suspended in $6 \mathrm{~mL}$ of acetonitrile, and an orange solution was observed. The mixture was stirred for $1 \mathrm{~h}$. The solvent was removed under reduced pressure. The solid was dissolved in $\mathrm{Et}_{2} \mathrm{O}(10 \mathrm{~mL})$ and filtered through a pad of Celite to remove $\mathrm{NaCl}$. The resulting orange solution was layered with petroleum ether to yield dark yellow crystals. Yield: $256.1 \mathrm{mg}$ (92\%). 
${ }^{1} \mathrm{H}$ NMR $\left(\mathrm{CDCl}_{3}, 400 \mathrm{MHz}\right): \delta 7.86\left(\mathrm{~d},{ }^{3} J_{\mathrm{HH}}=2.4 \mathrm{~Hz}, 1 \mathrm{H}, \mathrm{H}_{\mathrm{Tp}}\right), 7.80$ $\left(\mathrm{d},{ }^{3} \mathrm{~J}_{\mathrm{HH}}=2.5 \mathrm{~Hz}, 1 \mathrm{H}, \mathrm{H}_{\mathrm{Tp}}\right), 7.78\left(\mathrm{~d},{ }^{3} \mathrm{~J}_{\mathrm{HH}}=2.4 \mathrm{~Hz}, 1 \mathrm{H}, \mathrm{H}_{\mathrm{Tp}}\right), 7.70(\mathrm{br}$ s, $8 \mathrm{H}, \mathrm{BAr}_{4}^{\mathrm{F}}$ ), $7.57\left(\mathrm{~d},{ }^{3} \mathrm{~J}_{\mathrm{HH}}=5.8 \mathrm{~Hz}, 1 \mathrm{H}, \mathrm{H}_{\text {pyridine }}\right), 7.51$ (br s, $5 \mathrm{H}$, BAr $\left._{4}{ }_{4}+\mathrm{H}_{\text {pyridine }}\right), 7.45\left(\mathrm{~d},{ }^{3} J_{\mathrm{HH}}=1.5 \mathrm{~Hz}, 1 \mathrm{H}, \mathrm{H}_{\mathrm{Tp}}\right), 7.36\left(\mathrm{~d},{ }^{3} J_{\mathrm{HH}}=1.5\right.$ $\left.\mathrm{Hz}, 1 \mathrm{H}, \mathrm{H}_{\mathrm{TP}}\right), 7.21\left(\mathrm{~d},{ }^{3} J_{\mathrm{HH}}=7.2 \mathrm{~Hz}, 1 \mathrm{H}, \mathrm{H}_{\text {pyridine }}\right), 7.00\left(\mathrm{~d},{ }^{3} J_{\mathrm{HH}}=2.1\right.$ $\left.\mathrm{Hz}, 1 \mathrm{H}, \mathrm{H}_{\text {imid }}\right), 6.90\left(\mathrm{t},{ }^{3} J_{\mathrm{HH}}=6.7,1.4 \mathrm{~Hz}, 1 \mathrm{H}, \mathrm{H}_{\text {pyridine }}\right), 6.73\left(\mathrm{~d},{ }^{3} J_{\mathrm{HH}}\right.$ $\left.=2.1 \mathrm{~Hz}, 1 \mathrm{H}, \mathrm{H}_{\mathrm{imid}}\right), 6.35\left(\mathrm{vt},{ }^{3} J_{\mathrm{HH}}=2.2 \mathrm{~Hz}, 1 \mathrm{H}, \mathrm{H}_{\mathrm{Tp}}\right), 6.22\left(\mathrm{vt},{ }^{3} \mathrm{~J}_{\mathrm{HH}}\right.$ $\left.=2.2 \mathrm{~Hz}, 1 \mathrm{H}, \mathrm{H}_{\mathrm{Tp}}\right), 6.00\left(\mathrm{vt},{ }^{3} J_{\mathrm{HH}}=2.3 \mathrm{~Hz}, 1 \mathrm{H}, \mathrm{H}_{\mathrm{Tp}}\right), 5.94\left(\mathrm{~d},{ }^{3} \mathrm{~J}_{\mathrm{HH}}=\right.$ $\left.1.5 \mathrm{~Hz}, 1 \mathrm{H}, \mathrm{H}_{\mathrm{Tp}}\right), 5.54\left(\mathrm{~d},{ }^{2} J_{\mathrm{HH}}=15.1 \mathrm{~Hz}, 1 \mathrm{H}, \mathrm{H}_{\text {bridge }}\right), 4.95(\mathrm{~d}, J=$ $\left.15.1 \mathrm{~Hz}, 1 \mathrm{H}, \mathrm{H}_{\text {bridge }}\right), 2.37\left(\mathrm{~s}, 3 \mathrm{H}, \mathrm{NCH}_{3}\right), 2.20\left(\mathrm{~s}, 3 \mathrm{H}, \mathrm{CH}_{3}\right) .{ }^{13} \mathrm{C}\left\{{ }^{1} \mathrm{H}\right\}$ NMR $\left(\mathrm{CDCl}_{3}, 101 \mathrm{MHz}\right): \delta 189.0\left(\mathrm{C}_{\text {imid }} \mathrm{Ru}\right), 161.7\left(\mathrm{q},{ }^{1} \mathrm{~J}_{\mathrm{B}-\mathrm{C}}=49.8\right.$ $\left.\mathrm{Hz}, \mathrm{BAr}_{4}{ }_{4}\right), 157.8\left(\mathrm{C}_{\mathrm{py}}\right), 157.1\left(\mathrm{C}_{\mathrm{py}}\right), 144.0(\mathrm{Tp}), 142.6(\mathrm{Tp}), 141.5$ $(\mathrm{Tp}), 136.3(\mathrm{Tp}), 136.2(\mathrm{Tp}), 136.2(\mathrm{Tp}), 135.6\left(\mathrm{C}_{\mathrm{py}}\right), 134.8\left(\mathrm{BAr}^{\mathrm{F}}{ }_{4}\right)$, $128.9\left(\mathrm{q},{ }^{2} J_{\mathrm{C}-\mathrm{F}}=27.9 \mathrm{~Hz}, \mathrm{BAr}_{4}^{\mathrm{F}}\right), 124.5\left(\mathrm{q},{ }^{1} J_{\mathrm{C}-\mathrm{F}}=272.2 \mathrm{~Hz}, \mathrm{BAr}^{\mathrm{F}}{ }_{4}\right)$, $123.9\left(\mathrm{C}_{\mathrm{py}}\right), 123.7\left(\mathrm{C}_{\mathrm{py}}\right), 122.9\left(\mathrm{C}_{\text {imid }}\right), 121.5\left(\mathrm{C}_{\text {imid }}\right), 117.5\left(\mathrm{BAr}_{4}{ }^{\mathrm{F}}\right)$, $106.6(\mathrm{Tp}), 106.6(\mathrm{Tp}), 106.5(\mathrm{Tp}), 54.8\left(\mathrm{CH}_{2}\right), 35.3\left(\mathrm{NCH}_{3}\right), 3.9$ $\left(\mathrm{CH}_{3}\right)$. Anal. Calcd. for $\mathrm{C}_{53} \mathrm{H}_{36} \mathrm{~B}_{2} \mathrm{~F}_{24} \mathrm{~N}_{10} \mathrm{Ru}: \mathrm{C} 45.74, \mathrm{H} 2.61, \mathrm{~N} 10.07$. Found: C 45.77, H 2.56, N 9.99.

$\left[T p R u\left(\kappa^{2}-C, N\right.\right.$-3-isopropyl-1-(2-picolyl)imidazol-2-ylidene) $\left(\eta^{2}\right.$ $\left.\left.\mathrm{CH}_{2}=\mathrm{CH}_{2}\right)\right]\left[\mathrm{BAr}_{4}{ }_{4}\right](5 \boldsymbol{b})$. [TpRu $\left(\kappa^{2}-\mathrm{C}, \mathrm{N}\right.$-picolyl $\left.\left.{ }^{i{ }^{i P} \mathrm{I}} \mathrm{I}\right) \mathrm{Cl}\right](110.2 \mathrm{mg}, 0.2$ $\mathrm{mmol})$ and $\mathrm{NaBAr}_{4}^{\mathrm{F}}(177.2 \mathrm{mg}, 0.2 \mathrm{mmol})$ were suspended in $6 \mathrm{~mL}$ of fluorobenzene under $1 \mathrm{~atm}$ of ethylene, and a dark yellow solution was observed. The mixture was stirred for $1 \mathrm{~h}$. The solvent was removed under reduced pressure. The solid was dissolved in $\mathrm{Et}_{2} \mathrm{O}$ (10 $\mathrm{mL}$ ) and filtered through a pad of Celite to remove $\mathrm{NaCl}$. The resulting yellow solution was layered with petroleum ether to yield yellow crystals. Yield: $272.8 \mathrm{mg}(97 \%) .{ }^{1} \mathrm{H}$ NMR $\left(\mathrm{CD}_{2} \mathrm{Cl}_{2}, 400 \mathrm{MHz}\right)$ : $\delta 7.97\left(\mathrm{~d},{ }^{3} J_{\mathrm{HH}}=2.0 \mathrm{~Hz}, 1 \mathrm{H}, \mathrm{H}_{\mathrm{Tp}}\right), 7.87\left(\mathrm{~d},{ }^{3} \mathrm{~J}_{\mathrm{HH}}=2.4 \mathrm{~Hz}, 1 \mathrm{H}, \mathrm{H}_{\mathrm{Tp}}\right)$, $7.82\left(\mathrm{~d},{ }^{3} \mathrm{~J}_{\mathrm{HH}}=2.4 \mathrm{~Hz}, 1 \mathrm{H}, \mathrm{H}_{\mathrm{Tp}}\right), 7.77\left(\mathrm{~d},{ }^{3} \mathrm{~J}_{\mathrm{HH}}=2.0 \mathrm{~Hz}, 1 \mathrm{H}, \mathrm{H}_{\mathrm{Tp}}\right)$, $7.71\left(\mathrm{br} \mathrm{s}, 9 \mathrm{H}, \mathrm{BAr}_{4}^{\mathrm{F}}+\mathrm{H}_{\mathrm{Tp}}\right), 7.69\left(\mathrm{t},{ }^{3} \mathrm{~J}_{\mathrm{HH}}=7.8 \mathrm{~Hz}, 1 \mathrm{H}, \mathrm{H}_{\text {pyridine }}\right), 7.64$ $\left(\mathrm{d},{ }^{3} \mathrm{~J}_{\mathrm{HH}}=5.9 \mathrm{~Hz}, 1 \mathrm{H}, \mathrm{H}_{\text {pyridine }}\right), 7.55\left(\mathrm{br} \mathrm{s}, 4 \mathrm{H}, \mathrm{BAr}_{4}^{\mathrm{F}}\right), 7.31\left(\mathrm{~d},{ }^{3} J_{\mathrm{HH}}=\right.$ $\left.6.7 \mathrm{~Hz}, 1 \mathrm{H}, \mathrm{H}_{\text {pyridine }}\right), 7.22\left(\mathrm{~d},{ }^{3} \mathrm{~J}_{\mathrm{HH}}=2.0 \mathrm{~Hz}, 1 \mathrm{H}, \mathrm{H}_{\text {imid }}\right), 7.06\left(\mathrm{~d},{ }^{3} \mathrm{~J}_{\mathrm{HH}}\right.$ $\left.=2.3 \mathrm{~Hz}, 1 \mathrm{H}, \mathrm{H}_{\text {imid }}\right), 6.97\left(\mathrm{t},{ }^{3} J_{\mathrm{HH}}=6.5 \mathrm{~Hz}, 1 \mathrm{H}, \mathrm{H}_{\text {pyridine }}\right), 6.46(\mathrm{vt}$, $\left.{ }^{3} J_{\mathrm{HH}}=2.2 \mathrm{~Hz}, 1 \mathrm{H}, \mathrm{H}_{\mathrm{Tp}}\right), 6.28\left(\mathrm{vt},{ }^{3} J_{\mathrm{HH}}=2.2 \mathrm{~Hz}, 1 \mathrm{H}, \mathrm{H}_{\mathrm{Tp}}\right), 6.07(\mathrm{vt}$, $\left.{ }^{3} J_{\mathrm{HH}}=2.4 \mathrm{~Hz}, 1 \mathrm{H}, \mathrm{H}_{\mathrm{Tp}}\right), 5.83\left(\mathrm{~d},{ }^{3} J_{\mathrm{HH}}=2.0 \mathrm{~Hz}, 1 \mathrm{H}, \mathrm{H}_{\mathrm{Tp}}\right), 4.91(\mathrm{~d}$, $\left.{ }^{2} J_{\mathrm{HH}}=16.1 \mathrm{~Hz}, 1 \mathrm{H}, \mathrm{H}_{\text {bridge }}\right), 4.71\left(\mathrm{~d},{ }^{2} J_{\mathrm{HH}}=16.1 \mathrm{~Hz}, 1 \mathrm{H}, \mathrm{H}_{\text {bridge }}\right), 4.02$ $\left(\mathrm{m}, 2 \mathrm{H}, \mathrm{CH}_{2}\right), 3.71\left(\mathrm{~m}, 2 \mathrm{H}, \mathrm{CH}_{2}\right), 2.79\left(\mathrm{~m},{ }^{3} J_{\mathrm{HH}}=6.6 \mathrm{~Hz}, 1 \mathrm{H}, \mathrm{NCH}\right)$, $1.09\left(\mathrm{~d},{ }^{3} J_{\mathrm{HH}}=6.8 \mathrm{~Hz}, 3 \mathrm{H}, \mathrm{CH}_{3}\right), 0.60\left(\mathrm{~d},{ }^{3} \mathrm{~J}_{\mathrm{HH}}=6.4 \mathrm{~Hz}, 3 \mathrm{H}, \mathrm{CH}_{3}\right)$. ${ }^{13} \mathrm{C}\left\{{ }^{1} \mathrm{H}\right\}$ NMR $\left(\mathrm{CD}_{2} \mathrm{Cl}_{2}, 100 \mathrm{MHz}\right): \delta 180.9\left(\mathrm{C}_{\text {imid }} \mathrm{Ru}\right), 162.1$ (q, $\left.{ }^{1} J_{\mathrm{B}-\mathrm{C}}=49.6 \mathrm{~Hz}, \mathrm{BAr}^{\mathrm{F}}{ }_{4}\right), 157.3\left(\mathrm{C}_{\mathrm{py}}\right), 156.9\left(\mathrm{C}_{\mathrm{py}}\right), 146.0(\mathrm{Tp}), 144.5$ (Tp), $143.2(\mathrm{Tp}), 138.3\left(\mathrm{C}_{\mathrm{py}}\right), 138.1(\mathrm{Tp}), 136.6(\mathrm{Tp}), 136.2(\mathrm{Tp})$, $135.2\left(\mathrm{BAr}_{4}^{\mathrm{F}}\right), 129.3\left(\mathrm{q},{ }^{2} J_{\mathrm{C}-\mathrm{F}}=35.3 \mathrm{~Hz}, \mathrm{BAr}^{\mathrm{F}}{ }_{4}\right), 125.1\left(\mathrm{C}_{\mathrm{py}}\right), 125.0$ $\left(\mathrm{q},{ }^{1} J_{\mathrm{C}-\mathrm{F}}=272.4 \mathrm{~Hz}, \mathrm{BAr}_{4}{ }_{4}\right), 124.6\left(\mathrm{C}_{\mathrm{py}}\right), 123.8\left(\mathrm{C}_{\text {imid }}\right), 118.7\left(\mathrm{C}_{\text {imid }}\right)$, $117.9\left(\mathrm{BAr}_{4}^{\mathrm{F}}\right), 107.5(\mathrm{Tp}), 107.1(\mathrm{Tp}), 106.8(\mathrm{Tp}), 70.8\left(\mathrm{CH}_{2}\right), 53.6$ $\left(\mathrm{CH}_{2}\right), 50.5(\mathrm{NCH}), 25.4\left(\mathrm{CH}_{3}\right), 22.7\left(\mathrm{CH}_{3}\right)$. Anal. Calcd. for $\mathrm{C}_{55} \mathrm{H}_{41} \mathrm{~B}_{2} \mathrm{~F}_{24} \mathrm{~N}_{9} \mathrm{Ru}$ : C 46.96, H 2.94, N 8.96. Found: C 47.04, H 2.88, $\mathrm{N} 9.03$.

[\{TpRu( ${ }^{2}-C, N$-3-methyl-1-(2-picolyl)imidazol-2-ylidene $\left.\left.)\right\}_{2}\left(\mu-S_{2}\right)\right]-$ $\left[\mathrm{BAr}_{4}\right]_{2}$ (6). [TpRu$\left(\kappa^{2}-C, N\right.$-picolyl- $\left.\left.{ }^{M e} \mathrm{I}\right) \mathrm{Cl}\right](105.5 \mathrm{mg}, 0.2 \mathrm{mmol})$, $\mathrm{NaBAr}_{4}{ }_{4}(177.2 \mathrm{mg}, 0.2 \mathrm{mmol}$ ), and an excess of sulfur (ca. 4 equiv) were suspended in $6 \mathrm{~mL}$ of fluorobenzene, and a dark yellow solution was observed. The mixture was stirred for $1 \mathrm{~h}$. The solvent was removed under reduced pressure. The solid was dissolved in $\mathrm{Et}_{2} \mathrm{O}$ (10 $\mathrm{mL}$ ) and filtered through a pad of Celite to remove $\mathrm{NaCl}$. The resulting orange solution was layered with petroleum ether to yield yellow crystals. Yield: $492.4 \mathrm{mg}(89 \%) .{ }^{1} \mathrm{H} \mathrm{NMR}\left(\mathrm{CD}_{2} \mathrm{Cl}_{2}, 400 \mathrm{MHz}\right)$ : $\delta 8.07\left(\mathrm{~m}, 2 \mathrm{H}, \mathrm{H}_{\mathrm{Tp}}\right), 7.88\left(\mathrm{~m}, 2 \mathrm{H}, \mathrm{H}_{\mathrm{Tp}}\right), 7.86\left(\mathrm{dd},{ }^{3} \mathrm{~J}_{\mathrm{HH}}=2.5,0.7 \mathrm{~Hz}\right.$, $\left.1 \mathrm{H}, \mathrm{H}_{\mathrm{Tp}}\right), 7.84\left(\mathrm{dd},{ }^{3} J_{\mathrm{HH}}=2.3,0.7 \mathrm{~Hz}, 1 \mathrm{H}, \mathrm{H}_{\mathrm{Tp}}\right), 7.71(\mathrm{br} \mathrm{s}, 18 \mathrm{H}$, $\mathrm{BAr}_{4}^{\mathrm{F}}+\mathrm{H}_{\text {pyridine }}$ ), 7.53 (br s, $10 \mathrm{H}, \mathrm{BAr}^{\mathrm{F}}{ }_{4}+\mathrm{H}_{\text {pyridine }}$ ), 7.27 (vt, ${ }^{3} \mathrm{~J}_{\mathrm{HH}}=$ $\left.2.1 \mathrm{~Hz}, 2 \mathrm{H}, \mathrm{H}_{\text {imid }}\right), 6.91\left(\mathrm{~m}, 2 \mathrm{H}, \mathrm{H}_{\text {pyridine }}\right), 6.87\left(\mathrm{~d},{ }^{3} \mathrm{~J}_{\mathrm{HH}}=5.9 \mathrm{~Hz}, 1 \mathrm{H}\right.$, $\left.\mathrm{H}_{\text {pyridine }}\right), 6.83\left(\mathrm{~d},{ }^{3} J_{\mathrm{HH}}=5.7 \mathrm{~Hz}, 1 \mathrm{H}, \mathrm{H}_{\text {pyridine }}\right), 6.83\left(\mathrm{~d},{ }^{3} J_{\mathrm{HH}}=2.1 \mathrm{~Hz}\right.$, $\left.2 \mathrm{H}, \mathrm{H}_{\text {imid }}\right), 6.60\left(\mathrm{~d},{ }^{3} J_{\mathrm{HH}}=1.6 \mathrm{~Hz}, 1 \mathrm{H}, \mathrm{H}_{\mathrm{Tp}}\right), 6.56\left(\mathrm{~d},{ }^{3} J_{\mathrm{HH}}=1.4 \mathrm{~Hz}\right.$, $\left.1 \mathrm{H}, \mathrm{H}_{\mathrm{Tp}}\right), 6.51\left(\mathrm{~d},{ }^{3} J_{\mathrm{HH}}=1.6 \mathrm{~Hz}, 1 \mathrm{H}, \mathrm{H}_{\mathrm{Tp}}\right), 6.45\left(\mathrm{~d},{ }^{3} J_{\mathrm{HH}}=1.4 \mathrm{~Hz}\right.$, $\left.1 \mathrm{H}, \mathrm{H}_{\mathrm{TP}}\right), 6.31\left(\mathrm{~m}, 4 \mathrm{H}, \mathrm{H}_{\mathrm{TP}}+\mathrm{H}_{\text {bridge }}\right), 6.19\left(\mathrm{~m}, 2 \mathrm{H}, \mathrm{H}_{\mathrm{Tp}}\right), 6.15(\mathrm{~m}$, $\left.2 \mathrm{H}, \mathrm{H}_{\mathrm{TP}}\right), 6.09\left(\mathrm{vt},{ }^{3} \mathrm{~J}_{\mathrm{HH}}=2.1 \mathrm{~Hz}, 1 \mathrm{H}, \mathrm{H}_{\mathrm{Tp}}\right), 6.05\left(\mathrm{vt},{ }^{3} J_{\mathrm{HH}}=2.1 \mathrm{~Hz}\right.$, $\left.1 \mathrm{H}, \mathrm{H}_{\mathrm{Tp}}\right), 5.21\left(\mathrm{~d},{ }^{2} J_{\mathrm{HH}}=16.2 \mathrm{~Hz}, 1 \mathrm{H}, \mathrm{H}_{\text {bridge }}\right), 5.19\left(\mathrm{~d},{ }^{2} J_{\mathrm{HH}}=16.2\right.$ $\left.\mathrm{Hz}, 1 \mathrm{H}, \mathrm{H}_{\text {bridge }}\right), 2.12\left(\mathrm{~s}, 3 \mathrm{H}, \mathrm{NCH}_{3}\right), 2.11\left(\mathrm{~s}, 3 \mathrm{H}, \mathrm{NCH}_{3}\right) .{ }^{13} \mathrm{C}\left\{{ }^{1} \mathrm{H}\right\}$ NMR $\left(\mathrm{CD}_{2} \mathrm{Cl}_{2}, 101 \mathrm{MHz}\right): \delta 174.3\left(\mathrm{C}_{\text {imid }} \mathrm{Ru}\right), 174.2\left(\mathrm{C}_{\text {imid }} \mathrm{Ru}\right), 162.1$ $\left(\mathrm{q},{ }^{1} J_{\mathrm{B}-\mathrm{C}}=49.9 \mathrm{~Hz}, \mathrm{BAr}^{\mathrm{F}}{ }_{4}\right), 156.4\left(\mathrm{C}_{\mathrm{py}}\right), 156.4\left(\mathrm{C}_{\mathrm{py}}\right), 156.1\left(\mathrm{C}_{\mathrm{py}}\right)$,
$156.0\left(\mathrm{C}_{\mathrm{py}}\right), 145.2(\mathrm{Tp}), 145.2(\mathrm{Tp}), 143.3(\mathrm{Tp}), 143.3(\mathrm{Tp}), 142.7$ (Tp), $142.6(\mathrm{Tp}), 139.5\left(\mathrm{C}_{\mathrm{py}}\right), 138.5(\mathrm{Tp}), 137.7(\mathrm{Tp}), 137.6(\mathrm{Tp})$, $136.8(\mathrm{Tp}), 135.2\left(\mathrm{BAr}_{4}^{\mathrm{F}}\right), 129.2\left(\mathrm{q},{ }^{2} J_{\mathrm{C}-\mathrm{F}}=31.5 \mathrm{~Hz}, \mathrm{BAr}_{4}^{\mathrm{F}}\right), 125.4$ $\left(\mathrm{C}_{\mathrm{py}}\right), 125.3\left(\mathrm{C}_{\mathrm{py}}\right), 125.3\left(\mathrm{C}_{\mathrm{py}}\right), 125.3\left(\mathrm{C}_{\mathrm{py}}\right), 124.9\left(\mathrm{q},{ }^{1} J_{\mathrm{C}-\mathrm{F}}=272.3\right.$ $\left.\mathrm{Hz}, \mathrm{BAr}_{4}^{\mathrm{F}}\right), 124.4\left(\mathrm{C}_{\text {imid }}\right), 124.3\left(\mathrm{C}_{\text {imid }}\right), 123.2\left(\mathrm{C}_{\text {imid }}\right), 123.1\left(\mathrm{C}_{\text {imid }}\right)$, $117.9\left(\mathrm{BAr}_{4}^{\mathrm{F}}\right), 109.4(\mathrm{Tp}), 107.2(\mathrm{Tp}), 107.1(\mathrm{Tp}), 106.9(\mathrm{Tp}), 55.6$ $\left(\mathrm{CH}_{2}\right)$, 55.5 $\left(\mathrm{CH}_{2}\right), 35.7\left(\mathrm{NCH}_{3}\right)$. Anal. Calcd. for $\mathrm{C}_{102} \mathrm{H}_{66} \mathrm{~B}_{4} \mathrm{~F}_{48} \mathrm{~N}_{18} \mathrm{Ru}_{2} \mathrm{~S}$ : C 44.30, H 2.41, N 9.12. Found: C 44.39, H 2.45, N 9.16 .

Experimental Determination of $K_{\text {eq }}$ for the Equilibrium between $3 d, 3^{\prime} d$, and $3^{\prime \prime} d$ and $3 e, 3^{\prime} e$, and $3^{\prime \prime} e$, and Its Dependence with Temperature. ${ }^{1} \mathrm{H}$ NMR integrals were used to calculate the percentage in solution of the species involved in the equilibrium. The equilibrium constant for the process shown in eq 2 is

$$
K_{\mathrm{eq}}=\frac{\left[3^{\prime \prime} \mathrm{d}\right]^{2}}{\left[\mathrm{~N}_{2}\right]\left[3 \mathrm{~d}-3^{\prime} \mathrm{d}\right]}
$$

The concentration of $\mathrm{N}_{2}$ in solution is assumed to be constant (equal to the solubility of $\mathrm{N}_{2}$ in nitromethane), given the experiment was conducted under a dinitrogen atmosphere in $\mathrm{N}_{2}$-saturated solvent. As the solution is saturated with $\mathrm{N}_{2}$, the temperature-dependence of the solubility was not taken into account in the equilibrium constant calculation. By measuring the concentration of the species in solution at different temperatures, the corresponding values of $K_{\text {eq }}$ can be determined. A plot of $\ln K_{\text {eq }}$ versus $1 / T$ allowed the calculation of $\Delta H^{\circ}$ and $\Delta S^{\circ}$ for the process.

Crystal Structure Analysis. Crystals of $1 \mathrm{~b}, \mathbf{2 a}, \mathbf{2 d}, \mathbf{3}^{\prime} \mathrm{a}, \mathbf{3}^{\prime} \mathrm{d}, 5 \mathrm{~b}, \mathbf{6}$ and $1 \mathrm{~b} \cdot 0.35 \mathrm{AgBr}$ suitable for X-ray structural determination were mounted on glass fibers and then transferred to the cold nitrogen gas stream of a Bruker Smart APEX CCD three-circle diffractometer $(T=$ $100 \mathrm{~K})$ with a sealed-tube source and graphite-monochromated Mo $\mathrm{K} \alpha$ radiation $(\alpha=0.71073 \AA)$, at the Servicio Central de Ciencia y Tecnología de la Universidad de Cádiz. Four sets of frames were recorded over a hemisphere of the reciprocal space by $\omega$ scans with $\delta(\omega)=0.30$ and an exposure of $10 \mathrm{~s}$ per frame. No significant decay was observed over the course of data collection. Intensity data were corrected for Lorentz and polarization effects and absorption corrections applied using SADABS. ${ }^{54}$ The structures were solved by direct methods and refined on $F^{2}$ by full-matrix least-squares (SHELX97) by using all unique data. ${ }^{55}$ All non-hydrogen atoms were refined anisotropically with hydrogen atoms included in calculated positions (riding model). Racemic twinning $\mathbf{3}^{\prime} \mathbf{a}$ was refined using TWIN and BASF instructions. For $\mathbf{2 a}, \mathbf{3}^{\prime} \mathbf{d}$, and $\mathbf{6}$, some disordered $\mathrm{CF}_{3}$ groups in the anion were refined split in two complementary orientations using displacement parameter restraints. The program ORTEP-3 was used for plotting. ${ }^{56}$ In the Supporting Information, Table $S 1$ summarizes the crystal data and data collection and refinement details for $\mathbf{1 b}, \mathbf{2 a}, \mathbf{2 d}, \mathbf{3}^{\prime} \mathbf{a}, \mathbf{3}^{\prime} \mathbf{d}, \mathbf{5 b}, \mathbf{6}$, and $\mathbf{1 b} \cdot 0.35 \mathrm{AgBr}$. CCDC 911352-911359 contain supplementary crystallographic data for this article. These data can be obtained free of charge on application to the CCDC, 12 Union Road, Cambridge CB2 1EZ, U.K. (Fax, +44-1223-336-033; E-mail, deposit@ccdc.cam.ac.uk) and via www.ccdc.cam.ac.uk/data_request/cif.

\section{ASSOCIATED CONTENT}

\section{S Supporting Information}

Experimental procedures for the synthesis of $\mathbf{1 c}-\mathbf{e}, \mathbf{2 a}-\mathbf{c}, \mathbf{3 e}$, $3^{\prime} \mathbf{e}, 3^{\prime \prime} \mathbf{e}, 4 \mathrm{~b}$, and $5 \mathrm{a}, \mathrm{CIF}$ files and crystallographic data for compounds $1 \mathbf{b}, \mathbf{2 a}, \mathbf{2 d}, \mathbf{3}^{\prime}$ a, $\mathbf{3}^{\prime} \mathbf{d}, \mathbf{5 b}$, 6, and $\mathbf{1 b} \cdot 0.35 \mathrm{AgBr}$, and van't Hoff plots. This material is available free of charge via the Internet at http://pubs.acs.org.

\section{AUTHOR INFORMATION}

\section{Corresponding Author}

*(P.V.) E-mail: pedro.valerga@uca.es.

\section{Notes}

The authors declare no competing financial interest. 


\section{ACKNOWLEDGMENTS}

We thank the Spanish MICINN (Project CTQ2010-15390) and "Junta de Andalucía" (PAI-FQM188 and Project of Excellence P08-FQM-03538) for financial support, Johnson Matthey plc for generous loans of ruthenium trichloride, and Dr. Rodrigo Alcántara who recorded the Raman spectroscopy data included in this article. F.E.F. acknowledges the spanish MICINN for a FPI fellowship (BES-2008-006635).

\section{REFERENCES}

(1) (a) Mercs, L.; Albrecht, M. Chem. Soc. Rev. 2010, 39, 1903-1912. (b) Díez-González, S.; Marion, N.; Nolan, S. P. Chem. Rev. 2009, 109, 3612-3676. (c) Hahn, F. E.; Jahnke, M. C. Angew. Chem., Int. Ed. 2008, 47, 3122-3172. (d) Nolan, S. P.; Clavier, H. Annu. Rep. Prog. Chem., Sect. B 2007, 103, 193-222. (e) Nolan, S. P. N-Heterocyclic Carbenes in Synthesis; Wiley-VCH: New York, 2006. (f) Herrmann, W. A. Angew. Chem., Int. Ed. 2002, 41, 1290-1309. (g) Bourissou, D.; Guerret, O.; Gabbai, F. P.; Bertrand, G. Chem. Rev. 2000, 100, 39-91.

(2) Normand, A. T.; Cavell, K. J. Eur. J. Inorg. Chem. 2008, 27812800.

(3) (a) Cabeza, J. A.; Damonte, M.; García-Álvarez, P.; Kennedy, A. R.; Pérez-Carreño, E. Organometallics 2011, 30, 826-833. (b) Hahn, F. E.; Naziruddin, A. R.; Hepp, A.; Pape, T. Organometallics 2010, 29, 5283-5288. (c) Song, G.; Li, X.; Song, Z.; Zhao, J.; Zhang, H. Chem.-Eur. J. 2009, 15, 5535-5544. (d) Lee, C.; Ke, W.; Chan, K.; Lai, C.; Hu, C.; Lee, H. Chem.-Eur. J. 2007, 13, 582-591. (e) Danopoulos, A. A.; Tsoureas, N.; Macgregor, S. A.; Smith, C. Organometallics 2007, 26, 253-263. (f) Lee, H. M.; Chiu, P. L.; Zeng, J. Y. Inorg. Chim. Acta 2004, 4313-4321.

(4) (a) Warsink, S.; Chang, I.; Weigand, J. J.; Hauwert, P.; Chen, J.; Elsevier, C. J. Organometallics 2010, 29, 4555-4561. (b) Gnanamgari, D.; Sauer, E. L. O.; Schley, N. D.; Butler, C.; Incarvito, C. D.; Crabtree, R. H. Organometallics 2009, 28, 321-325.

(5) (a) Nielsen, D. J.; Cavell, K. J.; Skelton, B. W.; White, A. H. Organometallics 2006, 25, 4850-4856. (b) Herrman, W. A.; Gooben, L. J.; Spiegler, M. J. Organomet. Chem. 1997, 547, 357-366.

(6) (a) Cross, E. D.; Bierenstiel, M. Coord. Chem. Rev. 2011, 255, 574-590. (b) Fliedel, C.; Braunstein, P. Organometallics 2010, 29, 5614-5626. (c) Fliedel, C.; Sabbatini, A.; Braunstein, P. Dalton Trans. 2010, 8820-8828. (d) Huynh, H. V.; Yeo, C. H.; Chew, Y. X. Organometallics 2010, 29, 1479-1486. (e) Wolf, J.; Labande, A.; Daran, J.; Poli, R. Eur. J. Inorg. Chem. 2007, 5069-5079.

(7) (a) Gandolfi, C.; Heckenroth, M.; Neels, A.; Laurenczy, G.; Albrecht, M. Organometallics 2009, 28, 5112-5121. (b) Moore, L. R.; Cooks, S. M.; Anderson, M. S.; Schanz, H.; Griffin, S. T.; Rogers, R. D.; Kirk, M. C.; Shaughnessy, K. H. Organometallics 2006, 25, 51515158.

(8) (a) Takaki, D.; Okayama, T.; Shuto, H.; Matsumoto, S.; Yamaguchi, Y.; Matsumoto, S. Dalton Trans. 2011, 1445-1447. (b) Downing, S. P.; Pogorzelec, P. J.; Danopoulos, A. A.; ColeHamilton, D. J. Eur. J. Inorg. Chem. 2009, 1816-1824. (c) Xie, L.; Sun, H.; Hu, D.; Liu, Z.; Shen, Q.; Zhang, Y. Polyhedron 2009, 28, 2585290. (d) Wang, B.; Wang, D.; Cui, D.; Gao, W.; Tang, T.; Chen, X.; Jing, X. Organometallics 2007, 26, 3167-3172. (e) Downing, S. P.; Conde Guadaño, S.; Pugh, D.; Danopulos, A. A.; Bellabarba, R. M.; Hanton, M.; Smith, D.; Tooze, R. P. Organometallics 2007, 26, 37623770. (f) Sun, H.; Hu, D.; Wang, Y.; Shen, Q.; Zhang, Y. J. Organomet. Chem. 2007, 692, 903-907. (g) Downing, S. P.; Danopoulos, A. A. Organometallics 2006, 25, 1337-1340.

(9) (a) Makino, T.; Yamasaki, R.; Azumaya, I.; Masu, H.; Saito, S. Organometallics 2010, 29, 6291-6297. (b) Amar, H. B.; Hassine, B. B.; Fischmeister, C.; Dixneuf, P. H.; Bruneau, C. Eur. J. Inorg. Chem. 2010, 4752-4756. (c) Schneider, N.; Kruck, M.; Bellemin-Laponnaz, S.; Wadepohl, H.; Gade, L. H. Eur. J. Inorg. Chem. 2009, 493-500. (d) Schneider, N.; Bellemin-Laponnaz, S.; Wadepohl, H.; Gade, L. H. Eur. J. Inorg. Chem. 2008, 5587-5598. (e) Bellemin-Laponnaz, S.; Gade, L. H. Coord. Chem. Rev. 2007, 251, 718-725. (f) Poyatos, M.;
Maisse-François, A.; Bellemin-Laponnaz, S.; Peris, E.; Gade, L. J. Organomet. Chem. 2006, 691, 2713-2720.

(10) (a) Pažiký, M.; Loos, A.; Ferreira, M. J.; Serra, D.; Vinokurov, N.; Rominger, F.; Jäkel, C.; Hashmi, A. S. K.; Limbach, M. Organometallics 2010, 29, 4448-4458. (b) Binobaid, A.; Iglesias, M.; Beetstra, D. J.; Kariuki, B.; Dervisi, A.; Fallis, I. A.; Cavell, K. J. Dalton Trans. 2009, 7099-7112. (c) Kaufhold, O.; Hahn, F. E.; Pape, T.; Hepp, A. J. Organomet. Chem. 2008, 693, 3435-3440. (d) Veige, A. S. Polyhedron 2008, 27, 3177-3189. (e) Pugh, D.; Boyle, A.; Danopoulos, A. A. Dalton Trans. 2008, 1087-1094. (f) Baya, M.; Eguillor, B.; Esteruelas, M. A.; Oliván, M.; Oñate, E. Organometallics 2007, 26, 6556-6563. (g) Wright, J. A.; Danopoulos, A. A.; Motherwell, W. B.; Carroll, R. J.; Ellwood, S. J. Organomet. Chem. 2006, 691, 5204-5210. (h) Tulloch, A. A. D.; Danopoulos, A. A.; Kleinhez, A.; Light, M. E.; Hursthouse, M. B.; Eastham, G. Organometallics 2001, 20, 2027-2031.

(11) (a) Stylianides, N.; Danopoulos, A. A.; Tsoureas, N. J. Organomet. Chem. 2005, 690, 5948-5958. (b) Song, G.; Zhang, Y.; Li, X. Organometallics 2008, 27, 1936-1943. (c) Danopoulos, A. A.; Pugh, D.; Wright, J. A. Angew. Chem., Int. Ed. 2008, 47, 9765-9767.

(12) (a) Kascatan-Nebioglu, A.; Panzner, M. J.; Tessier, C. A.; Cannon, C. L.; Youngs, W. J. Coord. Chem. Rev. 2007, 251, 884-895. (b) Catalano, V.; Etogo, A. O. J. Organomet. Chem. 2005, 690, 60416050.

(13) (a) Tulloch, A. A. D.; Winston, S.; Danopuolos, A. A.; Eastham, G.; Hursthouse, M. B. Dalton Trans. 2003, 699-708. (b) Tulloch, A. A. D.; Danopoulos, A. A.; Tooze, R. P.; Cafferkey, S. M.; Kleinhenz, S.; Hursthouse, M. B. Chem. Commun. 2000, 1247-1248.

(14) (a) Pozo, C.; Iglesias, M.; Sánchez, F. Organometallics 2011, 30, 2180-2188. (b) Chang, W.; Chen, H.; Li, T.; Hsu, N.; Tingare, Y. S.; Li, C.; Liu, Y.; Su, C.; Li, W. Angew. Chem., Int. Ed. 2010, 49, 81618164. (c) Son, S. U.; Park, K. H.; Lee, Y.; Kim, B. Y.; Choi, C. H.; Lah, M. S.; Jang, Y. H.; Jang, D.; Chung, Y. K. Inorg. Chem. 2004, 43, 68966898.

(15) (a) Benítez Junquera, L.; Puerta, M. C.; Valerga, P. Organometallics 2012, 31, 2175-2183. (b) Wang, X.; Liu, S.; Weng, L.; Jin, G. J. Organomet. Chem. 2005, 690, 2934-2940. (c) Wang, X.; Liu, S.; Jin, G. Organometallics 2004, 23, 6002-6007.

(16) Warsink, S.; van Aubel, C. M. S.; Weigand, J. J.; Liu, S. T.; Elsevier, C. J. Eur. J. Inorg. Chem. 2010, 5556-5562.

(17) (a) Trofimenko, S. Polyhedron 2004, 43, 197-203. (b) Pettinari, C.; Santini, C. In Comprehensive Coordination Chemistry II; McCleverty, J. A., Meyer, T. J., Eds.; Pergamon: Oxford, U.K., 2004; Vol. 1, pp 159-210. (c) Trofimenko, S. Chem. Rev. 1993, 93, 943980. (d) Trofimenko, S. Prog. Inorg. Chem. 1986, 34, 115. (e) Trofimenko, S. J. Am. Chem. Soc. 1966, 88, 1842-1844.

(18) (a) Beach, N. J.; Williamson, A. E.; Spivak, G. J. J. Organomet. Chem. 2005, 690, 4640-4647. (b) Brunker, T. J.; Grenn, J. C.; O'Hare, D. Inorg. Chem. 2003, 42, 4366-4381. (c) Bergman, R. G.; Cundari, T. R.; Gillespie, A. M.; Gunnoe, T. B.; Harman, W. D.; Klinckman, T. R.; Temple, M. D.; White, D. P. Organometallics 2003, 22, 2331-2337. (d) Tellers, D. M.; Bergman, R. G. Organometallics 2001, 20, 4819-4832. (e) Tellers, D. M.; Bergman, R. G. J. Am. Chem. Soc. 2000, 122, 954-955. (f) Gemel, C.; Trimmel, G.; Slugovc, C.; Kremel, S.; Mereiter, K.; Schmid, R.; Kirchner, K. Organometallics 1996, 15, 3998-4004. (g) Curtis, M. D.; Shiu, K. B.; Butler, W. M.; Huffman, J. C. J. Am. Chem. Soc. 1986, 108, 3335-3343. (h) Sharp, P. R; Bard, A. J. Inorg. Chem. 1983, 22, 2689-2693.

(19) (a) Huang, J.; Schanz, H.; Stevens, E. D.; Nolan, S. P. Organometallics 1999, 18, 2370-2375. (b) Gemel, C.; Huffman, J. C.; Caulton, K. G.; Mauthner, K.; Kirchner, K. J. Organomet. Chem. 2000, 593-594, 342-353. (c) Jiménez-Tenorio, M.; Mereiter, K.; Puerta, M. C.; Valerga, P. J. Am. Chem. Soc. 2000, 122, 11230-11231. (d) Halikhedkar, A.; Jiménez-Tenorio, M.; Puerta, M. C.; Valerga, P. Organometallics 2002, 21, 628-635. (e) Jiménez-Tenorio, M.; Puerta, M. C.; Valerga, P. Eur. J. Inorg. Chem. 2004, 17-32. (f) Bosson, J.; Poater, A.; Cavallo, L.; Nolan, S. P. J. Am. Chem. Soc. 2010, 132, 13146-13149. 
(20) Huang, J.; Stevens, E. D.; Nolan, S. P.; Petersen, J. L. J. Am. Chem. Soc. 1999, 121, 2674-2678.

(21) Huang, J.; Jafarpour, L.; Hillier, A. C.; Stevens, E. D.; Nolan, S. P. Organometallics 2001, 20, 2878-2882.

(22) (a) Baratta, W.; Herrmann, W. A.; Rigo, P.; Scharwz, J. J. Organomet. Chem. 2000, 593-594, 489-493. (b) Baratta, W.; Herdweck, E.; Herrmann, W. A.; Rigo, P.; Schawrz, J. Organometallics 2002, 21, 2101-2106.

(23) Pontes da Costa, A.; Mata, J. A.; Royo, B.; Peris, E. Organometallics 2010, 29, 1832-1838.

(24) Fernández, F. E.; Puerta, M. C.; Valerga, P. Organometallics 2011, 30, 5793-5802.

(25) Sandford, M. S.; Love, J. A.; Grubbs, R. H. Organometallics 2001, 20, 4314-5318.

(26) Burtscher, D.; Perner, B.; Mereiter, K.; Slugovc, C. J. Organomet. Chem. 2006, 691, 5423-5430.

(27) (a) Singh, V. K.; Bustelo, E.; de los Ríos, I.; Macías-Arce, I.; Puerta, M. C.; Valerga, P.; Ortuño, M. A.; Ujaque, G.; Lledós, A. Organometallics 2011, 30, 4014-4031. (b) de los Ríos, I.; Bustelo, E.; Puerta, M. C.; Valerga, P. Organometallics 2010, 29, 1740-179. (c) Jiménez-Tenorio, M.; Palacios, M. D.; Puerta, M. C.; Valerga, P. J. Mol. Catal. Chem. 2007, 261, 64-72. (d) Jiménez-Tenorio, M.; Palacios, M. D.; Puerta, M. C.; Valerga, P. Organometallics 2005, 24, 3088-3098. (e) Jiménez-Tenorio, M. A.; Jiménez-Tenorio, M.; Puerta, M. C.; Valerga, P. Organometallics 2000, 19, 1333-1342. (f) JiménezTenorio, M. A.; Jiménez-Tenorio, M.; Puerta, M. C.; Valerga, P. Organometallics 1997, 16, 5528-5535.

(28) Pavlik, S.; Kirchner, K.; Mereiter, K. Deposition number CCDC-655657; CCDC: Cambridge, U.K., 2007.

(29) Fernández, F. E.; Puerta, M. C.; Valerga, P. Organometallics 2012, 31, 6868-6879.

(30) (a) Pavlik, S.; Schmid, R.; Kirchner, K.; Mereiter, K. Monatsh. Chem. 2004, 135, 1349-1357. (b) Standfest-Hauser, C. M.; Mereiter, K.; Schmid, R.; Kirchner, K. Organometallics 2004, 23, 2194-2196. (c) Ruba, E.; Simanko, W.; Mereiter, K.; Schmid, R; Kirchner, K. Inorg. Chem. 2000, 39, 382-384. (d) Slugvoc, C.; Schmid, R.; Kirchner, K. Coord. Chem. Rev. 1999, 185-186, 109-126.

(31) (a) Mata, J. A.; Poyatos, M.; Peris, E. Coord. Chem. Rev. 2007, 251, 841-859. (b) Cheng, Y.; Xu, H.; Sun, J.; Li, Y.; Chen, X.; Xue, Z. Dalton Trans. 2009, 7132-7140. (c) Zeng, F.; Yu, Z. Organometallics 2008, 27, 6025-6028. (d) Danopoulos, A. A.; Winston, S.; Motherwell, W. B. Chem. Commun. 2002, 1376-1377.

(32) Jiménez-Tenorio, M.; Puerta, M. C.; Valerga, P. Inorg. Chem. 2010, 49, 6035-6057.

(33) (a) Cambridge Crystallographic Data Center. Mogul: Retrieval of Crystallographically-Derived Molecular Geometry Information from CSD, version 1.4 (Build RC5); CCDC: Cambridge, U.K., 2011 (b) Bruno, I. J.; Cole, J. C.; Kessler, M.; Luo, J.; Motherwell, W. D. S.; Purkis, L. H.; Smith, B. R.; Taylor, R.; Cooper, I.; Harris, S. E.; Orpen, A. G. J. Chem. Inf. Comput. Sci. 2004, 44, 2133-2144.

(34) Bennet, M. A.; Byrnes, M. J.; Chung, G.; Edwards, A. J.; Willis, A. C. Inorg. Chim. Acta 2005, 358, 1692-1708.

(35) Chatt, J.; Nokolsky, A. B.; Richards, R. L.; Sanders, J. R. Chem. Commun. 1969, 154.

(36) Creutz, C.; Taube, H. Inorg. Chem. 1971, 10, 2664-2667.

(37) Jolly, P. W.; Jonas, K.; Krüger, C.; Tsay, Y. H. J. Organomet. Chem. 1971, 33, 109-122.

(38) Coia, G. M.; Demadis, K. D.; Meyer, T. J. Inorg. Chem. 2000, 39, 2212-2223.

(39) (a) Jiménez-Tenorio, M. A.; Jiménez-Tenorio, M. J.; Puerta, M. C.; Valerga, P. J. Chem. Soc., Dalton Trans. 1998, 3601-3608. (b) Jiménez-Tenorio, M. A.; Jiménez-Tenorio, M. J.; Puerta, M. C.; Valerga, P. Inorg. Chim. Acta 1997, 259, 77-80.

(40) (a) Joslin, E. E.; McMullin, C. L.; Gunnoe, T. B.; Cundari, T. R.; Sabat, M.; Myers, W. H. Organometallics 2012, 31, 6851-6860. (b) Foley, N. A.; Lail, M.; Lee, J. P.; Gunnoe, T. B.; Cundari, T. T.; Petersen, J. L. Organometallics 2007, 26, 5507-5516. (c) Foley, N. A.; Lail, M.; Lee, J. P.; Gunnoe, T. B.; Cundari, T. T.; Petersen, J. L. J. Am. Chem. Soc. 2007, 129, 6765-6781.
(41) (a) Borguet, Y.; Sauvage, X.; Zaragoza, G.; Demonceau, A.; Delaude, L. Organometallics 2011, 30, 2730-2738. (b) Sauvage, X.; Borguet, Y.; Demonceau, A.; Delaude, L. Macromol. Symp. 2010, 293, 24-27. (c) Borguet, Y.; Sauvage, X.; Zaragoza, G.; Demonceau, A.; Delaude, L. Adv. Synth. Catal. 2009, 351, 441-455.

(42) (a) Wolf, J.; Thommes, K.; Brief, O.; Scopelliti, R.; Severin, K. Organometallics 2008, 27, 4464-4474. (b) Quebatte, L.; Solari, E.; Scopelliti, R.; Severin, K. Organometallics 2005, 24, 1404-1406.

(43) Miranda-Soto, V.; Grotjahn, D. B.; Cooksy, A. L.; Golen, J. A.; Moore, C. E.; Rheingold, A. L. Angew. Chem., Int. Ed. 2011, 50, 631635.

(44) (a) Jiménez-Tenorio, M.; Palacios, M. D.; Puerta, M. C.; Valerga, P. Organometallics 2004, 23, 504-510. (b) de los Ríos, I.; Jiménez-Tenorio, M.; Padilla, J.; Puerta, M. V.; Valerga, P. Organometallics 1996, 15, 4565-4674. (c) Lindner, F.; Haustein, M.; Fawzi, R.; Steinmann, M.; Wegner, P. Organometallics 1994, 13, 5021-5029.

(45) (a) Ruba, E.; Gemel, C.; Slugovc, C.; Mereiter, K.; Schmid, R.; Kirchner, K. Organometallics 1999, 18, 2275-2280. (b) Slugovc, C.; Mauthner, K.; Kacetl, M.; Mereiter, K.; Schmid, R.; Kirchner, K. Chem.-Eur. J. 1998, 4, 2043-2050.

(46) (a) Coto, A.; de los Ríos, I.; Jiménez-Tenorio, M.; Puerta, M. C.; Valerga, P. J. Chem. Soc., Dalton. Trans. 1999, 4309-4314. (b) Coto, A.; Jiménez-Tenorio, M.; Puerta, M. C.; Valerga, P. Organometallics 1998, 17, 4392-4399.

(47) Amarasekara, J.; Rauchfuss, T. B.; Wilson, S. R. Inorg. Chem. 1987, 26, 3328-3332.

(48) (a) Cornell, C. N.; Sigman, M. S. In Activation of Small Molecule; Tolman, W. B., Ed.; Wiley-VCH: Weinheim, Germany, 2006; pp 159186. (b) Punniyamurthy, T.; Velusamy, S.; Iqbal, J. Chem. Rev. 2005, 105, 2329-2364. (c) Klotz, I. M.; Kurtz, D. M. Chem. Rev. 1994, 94, $567-568$.

(49) Häller, L. J. L.; Mas-Marzá, E.; Moreno, A.; Lowe, J. P.; Macgregor, S. A.; Mahon, M. F.; Pregosin, P. S.; Whittlesey, M. K. J. Am. Chem. Soc. 2009, 131, 9618-9619.

(50) McGuinness, D. S.; Cavell, K. J. Organometallics 2000, 19, 741748.

(51) Gruendemann, S.; Kovacevic, A.; Albrecht, M.; Faller, J. W.; Crabtree, R. H. J. Am. Chem. Soc. 2002, 124, 10473-10481.

(52) Tulloch, A. A. D.; Danopoulos, A. A.; Winston, S.; Kleinhenz, S.; Eastham, G. J. Chem. Soc., Dalton Trans. 2000, 4499-4506.

(53) Bahr, S. R.; Boudjouk, P. J. Org. Chem. 1992, 57, 5545-5547.

(54) Sheldrick, G. M. SADABS, 2001 version; University of Göttingen: Göttingen, Germany, 2001.

(55) (a) Sheldrick, G. M. SHELXTL, version 6.10, Crystal Structure Analysis Package; Bruker AXS: Madison, WI, 2000. (b) Sheldrick, G. M. Acta Crystallogr. 2008, A64, 112-122.

(56) Farrugia, L. J. J. Appl. Crystallogr. 1997, 30, 565. 